Bulletin No. 312

$$
\text { Series }\left\{\begin{array}{l}
\text { A, Economic Geology, } 92 \\
\text { D, Petrography and Mineralogy, } 36 \\
\text { E, Ohemistry and Physics, } 50
\end{array}\right.
$$

DEPARTMENT OF THE INTERIOR

UNITED STITES GEOLOGICAL SURVEY

CHARLES D: WALCO'TI, WHRECTOK

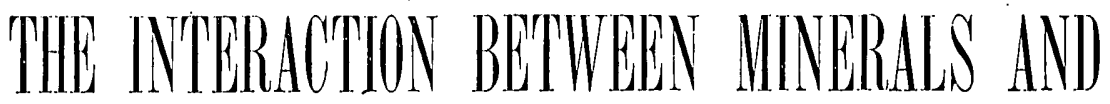 WATER SOLUTIOIS \\ WI'TH
}

\section{SPBCALL REAERERICE TO GEOLOGIC PHENOMBNA}

BY

EUGENE C. SULLIVAN

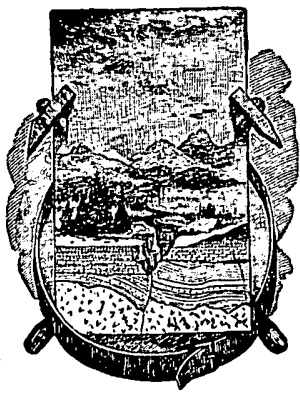

WASHINGTON

GOVERNMENT PRINTING OFEICE

1.907 



\section{CONTENTS.}

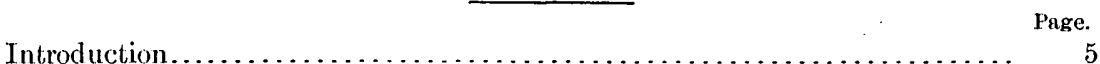

Outline of earlier work......................................... 7

Filtration and diffusion................................... 7

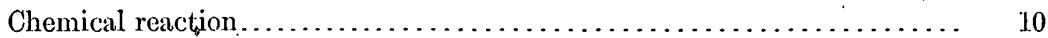

Alkaline solution ..................................... 28

Precipitation of acid ion................................ 30

Influence of calcium carbonate.......................... 31

Application of mass law..................................... 33

Influence of concentration................................ 34

Experimental work........................................... 37

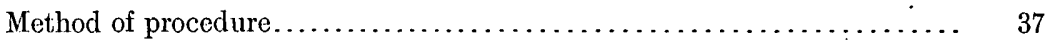

Experimental results......................................... 38

Kaolin and cupric sulphate.............................. $\quad 38$

Influence of surface...................................... 39

Orthoclase and salt solutions............................. $\quad 40$

Orthoclase and cupric sulphate............................ 41

Influence of concentration............................ 42

Influence of temperature............................. $\quad 42$

Orthoclase with cupric sulphate and sulphuric acid ............. 43

Orthoclase and cupric nitrate.............................. 43

Orthoclase and cupric chloride.......................... 44

Orthoclase and silver sulphate.............................. 44

Orthoclase and lead nitrate................................. 44

Orthoclase and gold chloride................................ 44

Orthoclase and zinc sulphate............................. 45

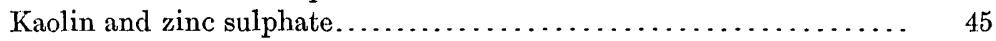

Orthoclase and ferrous sulphate.......................... 46

Kaolin and ferrous sulphate............................ 46

Orthoclase and ferric sulphate.............................. 46

Orthoclase and manganous sulphate......................... 47

Orthoclase and nickel sulphate.......................... $\quad 47$

Orthoclase and magnesium sulphate........................ 47

Orthoclase and calcium chloride.......................... 48

Orthoclase and strontium chloride.......................... 48

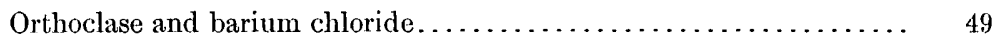

Orthoclase and potassium chloride......................... 49

Orthoclase and sodium chloride........................... 50

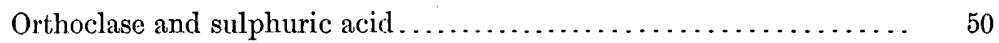

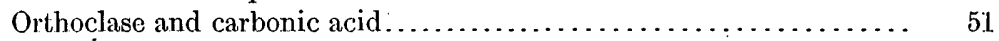

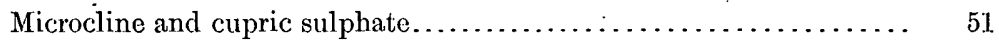

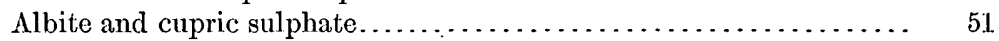

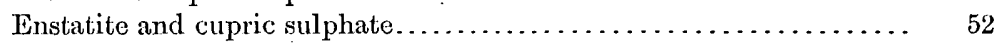

Augite and cupric sulphate........................... 52 
Experimental work-Continued.

Experimental results-Continued.

Anthophyllite and cupric sulphate...................... 53

Amphibole and cupric sulphate.......................... 53

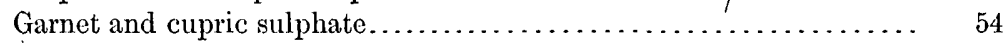

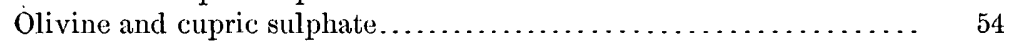

Vesuvianite and cupric sulphate.......................... 55

Epidote and cupric sulphate............................ 55

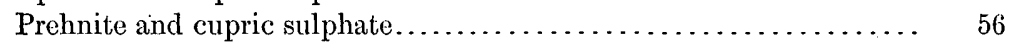

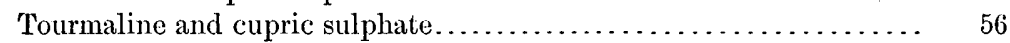

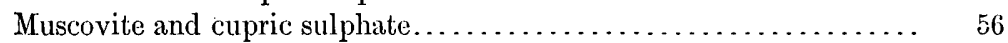

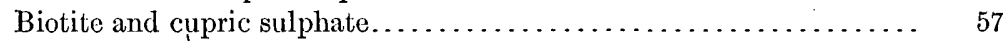

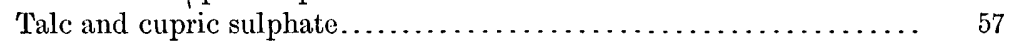

Shale and cupric sulphate.............................. 58

Clay gouge and cupric sulphate........................... 58

Clay gouge and silver sulphate............................. 59

Calcite (Iceland spar) and cupric sulphate................. 59

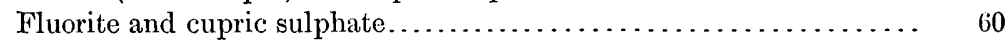

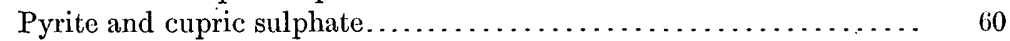

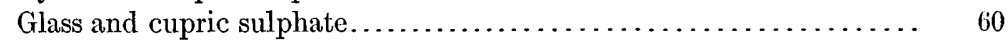

Possible application to geologic phenomena..................... $\quad 60$

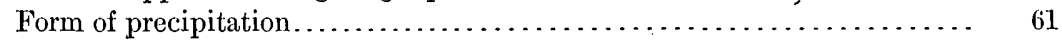

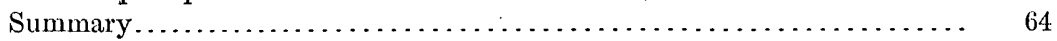

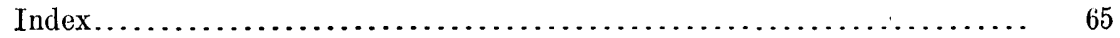




\title{
THE INTERACTION BETWEEN MINERALS AND WATER SOLUTIONS, WITH SPECIAL REFERENCE TO GEOLOGIC PHENOMENA.
}

\author{
By Eugene C. Sultivan.
}

\section{INTRODUCTION.}

The work described in the following pages was undertaken in the chemical laboratory of the United States Geological Survey, in an attempt to apply chemical methods to the investigation of geologic processes and especially of the secondary deposition of ores.

The concentration of metals by water solutions in deposits of sufficient magnitude to constitute ore bodies involves two processesthe taking up of the metal from its original seat, and its redeposition at a point favorable for accumulation. As to the first process, water, and especially water solutions, must be assumed to attack and dissolve to a greater or less extent all minerals with which they come into contact. Various causes will lessen or increase the extent of this action in the case of any particular mineral; but in every instance, no matter how infinitesimal the quantity dissolved as measured by ordinary laboratory standards, the solubility is capable, through long periods of time, of producing important geologic effects. Tho process of solution therefore involves no special difficulties.

Chief interest will center on the deposition, in one spot, of a mass of metal gathered by the solvent waters from over a wide range of country. It is important both from a scientific and from an economic point of view to know what agent determines that the metal from an immense volume of solution, which has passed undisturbed through a section of rock very large in comparison with that in which it is finally concentrated, shall be deposited in a certain limited area, to constitute a valuable body of ore. Physical conditions, such as comminution of the rock, stagnation of the carrying waters, local variations in temperature, or mingling of solutions, may have been important factors. They become important, however, chiefly in so far as they accelerate or otherwise modify chemical reactions, and a thorough knowledge of the reactions possible under natural conditions seems to be a necessary foundation for study along this line. 
With this in view some of the changes that take place at ordinary temperature when water solutions are brought into contact with rock-forming minerals have been examined.

The result has been, in a word, to make it apparent that chemical reaction between silicates and salt solutions is a very general phenomenon, taking place to a decided extent immediately upon contact, and that the outcome is mainly an exchange of bases in chemically equivalent quantities between solid and solution; the metal of the dissolved salt is precipitated and an equivalent quantity of silicate is decomposed and its bases enter the solution. Salt solutions as decomposing agents are much more active than pure water and are comparable with acids in this respect.

A review, as brief as possible, has been made of our present knowledge of the reactions between salt solutions and silicates in so far as it seems likely to have bearing on geologic work. The fact that no connected survey of this field exists and that the literature is scattered, most of the early papers having appeared in agricultural journals not readily accessible as a rule to the geologist and mineralogist, perhaps justifies the expectation that such an outline will prove useful. By no means all of the published papers bearing on the subject are mentioned in the text; the treatment has been confined to the briefest statement consistent with the development of the facts: ${ }^{a}$

The work described in the present paper is but an incomplete outline of a part of the field. Important work to be done suggests itself at once.

The investigation should be extended both as to salt solutions and as to minerals.

The character of the precipitates obtained by interaction between - salt solutions and minerals should be investigated by grinding the minerals in the solutions, which should give the end products in a comparatively short time by abrading the surfaces already acted upon and continually exposing fresh material to the solution.

The action of minerals on mixtures of salts in solution, and thus possible natural processes of separation, should be studied.

Where separation of metals has taken place, caused apparently by difference in character of wall rock, the opportunity and desirability of laboratory investigation are obvious.

Equilibrium conditions are still to be worked out. These are of great interest, both scientifically and practically, as showing the possibility of decomposition or the direction of decomposition of a mineral as dependent on the make-up of the solution with which it is in contact.

$a$ References to the literature on this and related subjects are assembled in Cameron, F. K., and Bell, J. M., The mineral constituents of the soil solution: U. S. Dept. Agr., Bull. Bur. Soils No. 30, 1905. 
It can not be doubted that the collection of definite comparative data along these lines will also throw light on questions of mineral constitution.

The possible practical effects of diffusion through wall rock, etc., should be ascertained experimentally.

\section{OUTLINE OF EARLIER WORK.}

\section{FILTRATION AND DIFFUSION.}

That water is improved for drinking purposes by filtration through sand was known as early as the time of Aristotle. ${ }^{a}$

Francis Bacon ${ }^{b}$ writes of a method of obtaining fresh water practiced on the coast of Barbary: "Digge a hole on the seashore somewhat above high-water mark and as deep as low-water mark, which when the tide cometh will be filled with water fresh and potable." He also remembers "to have read that trial hath been made of salt water passed through earth through ten vessels, one witnin another, and yet it hath not lost its saltness as to become potable," but when "drayned through twenty vessels hath become fresh."

Dr. Stephen Hales ${ }^{c}$ mentions, on the authority of Boyle Godfrey, that "sea water being filtered through stone cisterns, the first pint that runs through will be like pure water, having no taste of the salt, but the next pint will be as salt as usual."

Berzelius filtered solutions of common salt through sand and found the first portions of the filtrate fresh. Matteucci ${ }^{d}$ obtained similar results with other salts.

Although such phenomena are attributable to adsorption-an accumulation of dissolved substance on the contact surface liquid-solid, the filtering medium with its large surface affording favorable conditions for such an effect-the possibility is to be considered that we are dealing with the result of the different diffusivity of the constituents of a solution. Each substance has its own velocity of diffusion, and where free passage is interfered with, as in the filtration of a water solution; the water, traveling more rapidly than the salts, may come through first.

Krawkow, ${ }^{e}$ on comparing pure water and solutions side by side, found that the water moved more rapidly through a soil. Briggs obtained similar results, which he attributed to the greater viscosity of the solutions. $f$

$a$ Sachsze, Agriculturchemie, p. 146.

$b$ In Sylva Sylvarum, quoted by Way, Jour. Roy. Agr. Soc., vol. 11, 1850, p. 316.

$c$ In a paper read before the Royal Society in 1739 on "Some Attempts to make Sea-Water Wholesome," cited by Way.

$d$ Sur les phénomenes physiques des corps vivants, Paris, 1847, p. 29, cited by Way.

e Jour. für Landwirtschaft, vol. 48, 1900, p. 209.

$f$ U. S. Dept. Agr., Bull. Bur. Soils No. 19, 1902. 
King, ${ }^{a}$ on filtering very dilute soil solutions (containing carbonates, sulphates, nitrates, and phosphates) through a porcelain filter, observed an increase in the concentration of the unfiltered portion. The matter was followed up by Briggs, who found in the case of $\mathrm{N} / 1000$ solutions of potassium sulphate, sodium bicarbonate, and potassium nitrate a decrease in the concentration of the filtrate and an increase, amounting to 2 or 3 per cent, in the concentration of that part of the unfiltered liquid nearest the filter. Sodium carbonate solution (N/1000) suffered the greatest loss (15 per cent) on filtering. "This would follow from the tube behaving as an imperfect semipermeable membrane, allowing the water to pass through the filter walls more readily than the dissolved salt."

When the material is somewhat readily penetrable but slight separation will be effected in this way. With relatively impervious material, however, important separation of the constituents of a solution is possible, as in dialysis of a salt solution through an animal membrane, leaving behind colloid matter, the velocity of diffusion of which is practically nil as compared with that of electrolytes. Still less pervious are the so-called semipermeable membranes, such as a film of precipitated cupric ferrocyanide, which permit the solvent to pass, but not the dissolved salt.

G. F. Becker ${ }^{b}$ suggested the possibility of natural concentration of metals by dialysis, the confining rock of an underground water channel acting as a septum.

Kohler ${ }^{c}$ describes experiments on the filtration of salt solutions through kaolin. Cupric sulphate and lead nitrate solutions, after passing through a layer of washed kaolin (some $20 \mathrm{~cm}^{3}$ of dilute solution with 25 grams kaolin in an ordinary glass funnel), contained but very little of the metals. Sodium chloride, sodium sulphace, and magnesium sulphate solutions under similar treatment took on acid reaction. Kohler attributes these results to adsorption-a selective concentration of dissolved substance, here the bases of the salts, on the surface of a solid-and discusses the possibility that concentration of metals by this means has led to the formation of ore bodies.

The writer, on filtering magnesium chloride and sodium chloride solutions through kaolin, as described by Kohler, found the filtrate faintly but distinctly acid to litmus. With sodium chloride the first 4 or 5 cubic centimeters of filtrate had about the same degree of acidity. as a solution 0.001 normal. Such acidity seems sufficiently accounted for by the exchange of the magnesium and sodium of these salts in part for the iron and aluminum of the kaolin, the salts of the latter metals undergoing extensive hydrolysis in dilute

a Briggs, U. S. Dept. Agr., Bull. Bur. Soils No. 19, 1902, p. 36 .

$b$ Mineral Resources U. S. for 1892, U. S. Geol. Survey, p. 156.

c Zeitsch r. prakt. Geol., vol, 11, 1903, p. 49. 
solution. The acidity observed is of the same order of magnitude as the quantity of trivalent bases found in dilute copper sulphate solution after contact with kaolin.

The acidity of a salt solution after filtration through a substance, such as kaolin, through which the liquid diffuses but slowly, may be due to some extent to the greater velocity of diffusion of the acid constituent of the salt, which is present owing to hydrolysis-the splitting up of a salt into its acid and base by the action of water:

$$
\begin{aligned}
& \mathrm{CuSO}_{4}+2 \mathrm{H}_{2} \mathrm{O}=\mathrm{Cu}(\mathrm{OH})_{2}+\mathrm{H}_{2} \mathrm{SO}_{4} . \\
& \mathrm{Fe}_{2}\left(\mathrm{SO}_{4}\right)_{3}+6 \mathrm{H}_{2} \mathrm{O}=2 \mathrm{Fe}(\mathrm{OH})_{3}+3 \mathrm{H}_{2} \mathrm{SO}_{4} .
\end{aligned}
$$

In water solutions of salts of heavy metals the base is present, to a greater or less extent, in the colloidal condition, and colloids are marked by their very slow rate of diffusion.

P. Rohland ${ }^{a}$ states that a certain clay was permeable to crystalloid solutes, such as sodium chloride, barium chloride, cupric sulphate, potassium dichromate, etc., while it was impermeable to colloids, such as ferric hydroxide, silicic acid, and dissolved starch.

Spring ${ }^{b}$ observed the separation of acid and base by diffusion and the consequent deposition of the metal hydroxide in media similar in character to a suspension of clay in water. The suspended materialin one case, gum mastic (an emulsion of the resin in water, a milky liquid obtained by pouring an alcoholic solution of mastic into water); in another, silica-was superposed in a column $15 \mathrm{~cm}$. in height on a concentrated solution of the salt and diffusion allowed to take place. Coagulation or sedimentation of the solid was caused immediately and the particles descended to the point at which their density and that of the solution were the same. The height to which flocculation extended was not the same for different salts. Above the cupric sulphate solution the layer in which flocculation took place reached a height of $11.5 \mathrm{~cm}$. The copper had diffused upward not more than 7 $\mathrm{cm}$., as shown by the absence of color and by the ferrocyanide test in a portion removed by means of a pipette. Sulphuric acid was, however, present in the higher $4.5 \mathrm{~cm}$. Other salts-aluminum chloride, ferric chloride, alum, magnesium chloride, zinc chloride-gave similar results. Above the layer of salts in each case free acid was found.

The flocculent deposit above the cupric sulphate solution, removed with a pipette and washed on a filter, was of yellow-green color and contained cupric hydroxide. Aluminum, iron, zinc, and magnesium were shown to be present in mastic precipitated by means of their salts in the same manner.

If, however, the turbid mastic was shaken with cupric sulphate or aluminum chloride solution, the flocks of mastic which formed did not 
retain copper or aluminum. Washed on a filter and tested, they gave no reactions for those metals.

"The decomposition of the salts depends then only on the condition that diffusion intervenes and that, in any case, agitation does not bring base and acid into contact." "The mastic suspension apparently performs the same office as a permeable wall in the sense that it retains the molecules of hydroxide in order to precipitate with them, while it allows the molecules of acid to pass mòre freely."

The same results were obtained when silica was used as the suspended material instead of mastic.

Bruni and Vanzetti ${ }^{a}$ have shown that in the diffusion of cupric sulphate solution through gelatine the sulphuric acid separated by hydrolysis travels appreciably faster than the base. The blue solution is preceded by a colorless layer containing acid. With ferric chloride similar results were observed.

A further cause to which may be attributed acidity of a solution after contact with a hydrated silicate is double decomposition between the salt and silicic acid, or alumino-silicic acid, the hydrogen of the latter replacing'in solution the metal of the salt. Such action takes place readily enough in alkaline solution: $\mathrm{H}_{2} \mathrm{SiO}_{3}+2 \mathrm{KOH}=\mathrm{K}_{2} \mathrm{SiO}_{3}+2 \mathrm{H}_{2} \mathrm{O}$. It is slight if at all measurable with neutral salts.

\section{CHEMICAL REACTION.}

That solutions may be deprived in part of their dissolved substances by sandy material has therefore long been well known. The fact that clays, soils, etc., enter into chemical exchange with solutions, giving off some things and taking up others, appears to have first been specifically recognized by H. S. Thompson, an Englishman, who published his observations in $1850 .^{b}$ Thompson found that ammonium sulphate solution filtered through soil or clay exchanged its ammonium for calcium. The filtrate contained chiefly calcium sulphate. Similar experiments with ammonium carbonate also showed a reaction between the dissolved substance and the solid.

The matter was taken up and studied in detail by J. Thomas Way, chemist to the Royal Agricultural Society, whose work is described in the journal of the society for 1850 and following years. ${ }^{c}$ Way found that when an ammonia solution passed through soil or clay the percolating liquid contained neither ammonia nor ammonium salts. His first experiment was carried out in a tube 20 inches long and of threefourths inch internal diameter, which when about two-thirds filled contained 2,800 grains (180 grams) of soil. The soil used had been dried in air. A 1.5 per cent solution of ammonia was used, and the

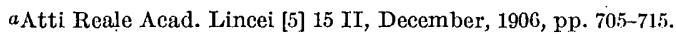

b Jour. Royal Agr. Soc., vol. 11, 1850, pp. 68-74.

.c Jour. Royal Agr. Soc., vol. 11, 1850, pp. 313-379; vol. 13, 1852, pp. 123-143; vol. 15, 1854, p. 491. 
first portions took from one and a half to two hoürs to percolate through the column. When one ounce $\left(30 \mathrm{~cm}^{3}\right)$ had passed, it was tested and found to contain no trace of ammonia or ammonium salts. Quantitative experiments showed that the soil had taken up ammonia equal in amount to about three-tenths of 1 per cent of its own weight. The result was the same on forcing the solution through by pressure, so that contact lasted but a few seconds.

Solutions of salts, such as the nitrates, chlorides, and sulphates of ammonium, potassium, sodium, and magnesium, filtered through soil gave up the respective bases entirely and received in exchange calcium from the soil. In the case of ammonium chloride it was shown that the chlorine content of the solution was not affected by contact with the soil. Filtration through a white pottery clay led to similar results, sodium being in this instance the substituting base; again the concentration of the chlorine was unchanged.

Way had no difficulty in proving that the active ingredient of the soil in absorption of bases was its clay. Owing to the relatively small proportion of base taken up by clay (a few tenths of 1 per cent of its weight), he concluded that the action was due, not to the clay as a. whole, but to some constituent present in small quantity. Evidence tending to show that this constituent was a hydrated alumino-silicate of alkali or alkaline earth he obtained by demonstrating that artificial alumino-silicates of sodium, potassium, calcium, magnesium, and ammonium were capable of exchanging bases with salt solutions exactly as the soils had done. It does not, however, follow that the soil contains zeolitic silicates which are responsible for such action, as has been sometimes assumed. ${ }^{a}$ Apparently any silicate, including the feldspars, is capable of entering into these reactions.

Sodium alumino-silicate was prepared by mixing sodium silicate and sodium aluminate solutions. The precipitate washed with water and dried was a white powder practically insoluble in water and containing some 18 per cent of soda. The other compounds were similarly prepared or were obtained from this one by substitution-the ammonium compound, for instance, by digesting with ammonium chloride solution, which removed sodium and formed an ammonium aluminosilicate.

Way clearly recognizes the nature of the phenomena with which he is dealing as the chemical replacement of one base by another. $\mathrm{He}$ says, for instance: " "It will be abundantly evident as we proceed that the absorptive power of soils is something entirely different from a surface attraction." Again, "the quantity of lime acquired by the solution corresponded exactly to that of the ammonia removed from it-the action was therefore a true chemical decomposition." $c$

a This point has been emphasized by Merrill, G. P., Rocks, Rock-Weathering, and Soils, New York, 1906, pp. 362-365.

b Loc. cit.; 1850.

$c$ Loc. cit., 1852. 
Way investigated also the influence of concentration and of temperature. The amount of exchange between solution and solid was found to increase with increasing concentration of the solution used, and to increase also, although but slightly, with rising temperature.

$\mathrm{He}$ observed that absorption was greater from alkaline than from neutral solution, and that absorption of free alkali (potassium hydroxide) was increased by previous boiling of the clay with hydrochloric acid. The cause of the latter phenomenon, the decomposition of silicates with resulting formation of colloid silica or silicic acids, he did not recognize.

, The relative ease with which the bases enter into these substitution reactions appears to depend somewhat upon the conditions of experimentation. Way makes the statement that sodium, potassium, calcium, magnesium, and ammonium will each be dislodged from its alumino-silicate by a salt of any of those following it in the order given. $^{a}$ Potassium should be with ammonium as one of the bases least readily replaced from silicates by substitution, not, as Way has it, at the other end of the series. He erroneously states that these changes are not reversible.

The capacity of the feldspars to enter into these reactions was not recognized by Way. He says: " "It is only in the state of hydrates that the double silicates possess the property in question; this is the reason why feldspar and albite substances, of the same composition in all other respects as the artificial silicates, are devoid of the power of absorbing ammonia."

Important to our present purpose, as illustrating the practical effect of silicates on organic matter, is the same author's description of the action of clay on barnyard liquors. These filtered through clay lost their color, odor, and taste. Sand was comparatively inefficient in this respect, although, as shown by Angus Smith, ${ }^{c}$ it had some oxidizing action, changing the nitrogen of organic compounds into nitrate.

Eichhorn $^{d}$ studied the reactions between salt solutions and individual natural minerals, such as chabasite, $\left(\mathrm{Ca}, \mathrm{Na}_{2}\right) \mathrm{Al}_{2}\left(\mathrm{SiO}_{3}\right)_{4}, 6 \mathrm{H}_{2} \mathrm{O}$, and natrolite, $\mathrm{Na}_{2} \mathrm{Al}_{2} \mathrm{Si}_{3} \mathrm{O}_{10}, 2 \mathrm{H}_{2} \mathrm{O}$. The following table shows the extent of substitution obtained with dilute solutions of the salts named. Four grams chabasite, finely powdered, 4 grams salt, 400 $\mathrm{cm}^{3}$ water were taken; contact was for ten days, presumably at room temperature:

Composition of chabasite as affected by salt solutions.

\begin{tabular}{|c|c|c|c|}
\hline & $\begin{array}{c}\text { Before } \\
\text { action } \\
\text { of salts. }\end{array}$ & $\begin{array}{c}\text { After } \\
\text { action } \\
\text { of } \mathrm{NaCl} \text {. }\end{array}$ & $\begin{array}{l}\text { After action of } \\
\text { NH.Cl. }\end{array}$ \\
\hline $\begin{array}{l}\mathrm{CaO}_{\mathrm{Na}} \mathrm{O} \\
.\end{array}$ & $\begin{array}{r}\text { Per cent. } \\
10.37 \\
0.42\end{array}$ & $\begin{array}{r}\text { Per cent. } \\
6.65 \\
5.40\end{array}$ & $\begin{array}{l}\text { Per cent. } \\
\begin{array}{c}4.15 \\
\left(\mathrm{NH}_{4}\right)_{2} \mathrm{O} \\
6.94\end{array}\end{array}$ \\
\hline
\end{tabular}

a Loc. cit., p. 132. b Loc. cit., p. $135 . \quad$ c Cited by Way, loc. cit. a Pogg. Aun., vol. 105, 1858, p. 126. 
Exchange has taken place in approximately equivalent quantities. Sodium carbonate and ammonium carbonate with chabasite gave similar results. The ammonium substitution product gave off no ammonia on heating to $100^{\circ}$, yet in contact at ordinary temperature with a solution containing chloride of calcium, sodium, potassium, or magnesium the ammonium was removed and the other base substituted. Eichhorn showed that these substitutions are reversible. After treatment with sodium chloride the altered chabasite, for instance, gave up sodium to calcium chloride solution. "The bases," he says, "appear to be mutually replaceable." He recognized the fact that some substitutions took place more readily than others, and as a measure of such ease of substitution he ascertained the time in which the salts of various bases drew calcium into solution from chabasite. The order found was as follows, those first in the list extracting a detectable amount of calcium most rapidly: Potassium, sodium, lithium, barium chlorides; cadmium nitrate; zinc, strontium, magnesium chlorides. This order, he remarks, may be modified by varying concentration of the salts.

Henneberg and Stohmann ${ }^{a}$ in 1858 described experiments confirming Way's results. They found that ammonium or potassium hydroxide, carbonate, nitrate, chloride, or sulphate in contact with soils of the widest variation in character gave up ammonium or potassium to form insoluble compounds. In the case of the nitrate, chloride, and sulphate-salts almost neutral in water-the acid content of the solution remained unchanged, the acid which had been combined with the absorbed ammonium or potassium reappearing in combination with calcium or magnesium. From solutions of phosphates, silicates, etc.-salts alkaline in water-the acid radical also was in part precipitated. Sodium and magnesium salts were found to behave like salts of ammonium and potassium. The following data are typical of those obtained in these experiments. The figures show the number of grams of ammonia $\left(\mathrm{NH}_{3}\right)$ absorbed by 100 grams of soil from $200 \mathrm{~cm}^{3}$ of solutions of the concentrations indicated.

Ammonia absorbed by soil from salıs of ammonium.

\begin{tabular}{|c|c|c|c|c|}
\hline & $\begin{array}{c}0.05 \text { gram } \\
\text { equivalent } \\
\text { per liter } \\
\left(0.17 \mathrm{~g} . \mathrm{NH}_{3}\right. \\
\left.\text { in } 200 \mathrm{~cm}^{3}\right) .\end{array}$ & $\begin{array}{l}0.1 \text { gram } \\
\text { equivalent } \\
\text { per liter } \\
\left(0.34 \mathrm{~g}^{\mathrm{NH}} \mathrm{N}_{3}\right. \\
\left.\text { in } 200 \mathrm{~cm}^{3}\right) \text {. }\end{array}$ & $\begin{array}{l}0.2 \text { gram } \\
\text { equivalent } \\
\text { per liter } \\
\left(0.68 \mathrm{~g} . \mathrm{NH}_{3}\right. \\
\left.\text { in } 200 \mathrm{~cm}^{3}\right) .\end{array}$ & $\begin{array}{l}\text { 0.5 gram } \\
\text { equivalent } \\
\text { per liter } \\
\left(1.7 \mathrm{~g} . \mathrm{NET}_{3}\right. \\
\left.\text { in } 200 \mathrm{~cm}^{3}\right)\end{array}$ \\
\hline 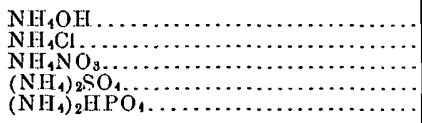 & $\begin{array}{l}0.058 \\
0.0545 \\
.0 .054 \\
0.057\end{array}$ & $\begin{array}{l}0.095 \\
0.071 \\
0.080 \\
0.086 \\
0.141\end{array}$ & $\begin{array}{l}0.149 \\
0.107 \\
0.106 \\
0.118 \\
0.206\end{array}$ & $\begin{array}{c}0.118 \\
{[0.170 ?]}\end{array}$ \\
\hline
\end{tabular}

The amount of ammonium taken from solution is about the same whether it is present as chloride, nitrate, or sulphate-salts which in water solution are almost neutral to indicators. With ammonium. 
hydroxide and ammonium phosphate-alkaline in water solutionthe quantity absorbed is somewhat greater.

Henneberg and Stohmann found also that the greater the quantity of solution taken with a fixed quantity of soil the greater was the absorption. In certain cases, for instance, doubling the amount of solution increased the amount of absorption one-fifth. The time of contact, as Way had already shown, was of little influence. Absorption was not greater in one hundred and sixty-eight hours than in four.

The authors compare the quantities of ammonium precipitated and calcium dissolved, but remain in doubt as to whether substitution in chemically equivalent amounts has taken place, possibly because they fail to determine the bases other than calcium taken from the soil by the solutions.

Peters ${ }^{a}$ investigated the action of soils on solutions of potassium salts, making complete analyses of the solutions after contact with the soils. The tables following indicate the general nature of the results. The data in the first table, obtained in four experiments carried out under conditions supposed to be identical, with $250 \mathrm{~cm}^{3}$ potassium chloride solution ( $\mathrm{N} / 20$, equivalent to 2.36 grams $\mathrm{K}_{2} \mathrm{O}$ per liter) and 100 grams soil, allow some estimate of the accuracy attained. The lack of agreement is undoubtedly due in part to actual nonuniformity in the experimental results and in part to the errors of analysis.

Action of soils on polassium chloride solution.

\begin{tabular}{|c|c|c|c|c|}
\hline \multirow{2}{*}{$\mathrm{K}$ absorbed equivalent to grams $\mathrm{K}_{2} \mathrm{O}$. } & \multicolumn{4}{|c|}{ Found in $250 \mathrm{~cm}^{3}$ solution- } \\
\hline & $\mathrm{CaO}$. & MgO. & $\mathrm{K}_{2} \mathrm{O}$. & $\mathrm{Na}_{2} \mathrm{O}$ \\
\hline $\begin{array}{l}0.2130 \ldots \ldots \\
0.2015 \ldots \ldots \\
0.1976 \ldots \ldots \\
0.1841 \ldots \ldots\end{array}$ & $\begin{array}{l}0.1176 \\
0.1176 \\
0.1120 \\
0.1064\end{array}$ & $\begin{array}{l}0.0032 \\
0.0048 \\
0.0049 \\
0.0050\end{array}$ & $\begin{array}{l}0.3758 \\
0.3873 \\
0.3912 \\
0.4047\end{array}$ & $\begin{array}{l}0.0463 \\
0.0439 \\
0.0370 \\
0.0450\end{array}$ \\
\hline
\end{tabular}

As showing the influence of the anion and of concentration the following data derived from the contact of 100 grams soil with $250 \mathrm{~cm}^{3}$ solution may be quoted from Peters:

Influence of anion and of concentration in action of soils on solutions of potassium salts.

\begin{tabular}{|c|c|c|c|c|}
\hline & \multirow{2}{*}{ Salt. } & \multirow{2}{*}{$\begin{array}{l}\text { Concen- } \\
\text { tration. }\end{array}$} & \multicolumn{2}{|c|}{$\begin{array}{l}\mathrm{K} \text {, expressed as grams } \\
\mathrm{K}_{2} \mathrm{O} .\end{array}$} \\
\hline & & & $\begin{array}{l}\text { Originally } \\
\text { in } 250 \mathrm{~cm}^{3} \text {. }\end{array}$ & $\begin{array}{l}\text { Absorbed } \\
\text { from } \\
250 \mathrm{~cm}^{3} .\end{array}$ \\
\hline 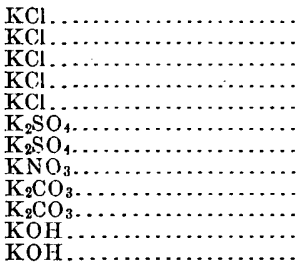 & 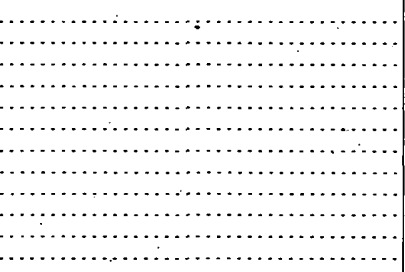 & $\begin{array}{l}N / 80 \\
N / 40 \\
N / 20 \\
N / 10 \\
N / 5 \\
N / 20 \\
N / 10 \\
N / 20 \\
N / 20 \\
N / 10 \\
N / 20 \\
N / 10\end{array}$ & $\begin{array}{l}0.1472 \\
0.2944 \\
0.5888 \\
1.1776 \\
2.3552 \\
0.5888 \\
1.1776 \\
0.5888 \\
0.5888 \\
1.1776 \\
0.5888 \\
1.1776\end{array}$ & $\begin{array}{l}0.0988 \\
0.1381 \\
0.1990 \\
0.3124 \\
0.4503 \\
0.2089 \\
0.3362 \\
0.2516 \\
0.2792 \\
0.4705 \\
0.4018 \\
0.7347\end{array}$ \\
\hline
\end{tabular}


Here again absorption from the salts in neutral solution is roughly the same whatever the form of combination, while from alkaline solution the absorption is greater. The slow increase in absorption as concentration rises is also exemplified. Peters found that the chloride and sulphate ions were not absorbed, while the phosphate ion was. The following order of absorption is given for the bases; that absorbed in greatest quantity being placed first: Potassium, ammonium, sodium, magnesium, calcium.

The bases dissolved from the soil were replaced in very nearly equivalent quantity by the absorbed base. From "bases dissolved" has been subtracted that quantity which is dissolved from the soil by water alone.

Comparison of bases dissolved with potassium absorbed from chloride solution.

\begin{tabular}{|c|c|c|}
\hline Original concentration & $\begin{array}{c}\text { Bases dis- } \\
\text { solved, } \\
\text { equivalent } \\
\text { to grams } \\
\mathrm{K}_{2} \mathrm{O}\end{array}$ & $\begin{array}{l}\mathrm{K} \text { ab- } \\
\text { sorbed, } \\
\text { equivalent } \\
\text { to grams } \\
\mathrm{K}_{2} \mathrm{O} \text {. }\end{array}$ \\
\hline 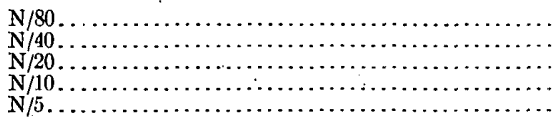 & $\begin{array}{l}0.0891 \\
0.1241 \\
0.2061 \\
0.3138 \\
0.4545\end{array}$ & $\begin{array}{l}0.1012 \\
0.1381 \\
0.1990 \\
0.3124 \\
0.4503\end{array}$ \\
\hline
\end{tabular}

The results of experiments by Peters on the absorption of potassium chloride from solution by wood charcoal are also of importance. The charcoal was washed with alcohol and ether and dilute nitric acid and carefully dried. The quantities are stated in grams.

Reaction between wood charcoal and potassium chloride solution.

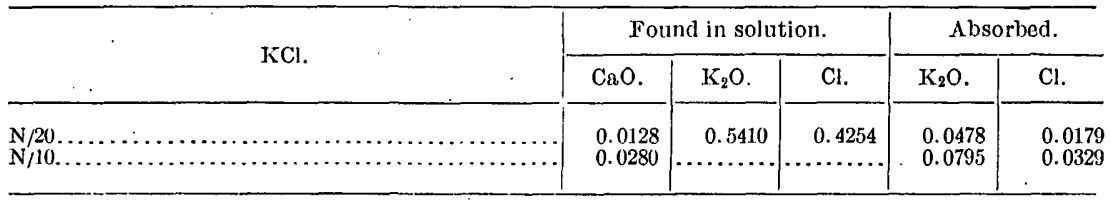

A certain amount of the entire salt has apparently been absorbed. The potassium absorbed in excess of that equivalent to the chlorine absorbed has been replaced in solution by an equivalent quantity of calcium.

Although recognizing that "for the absorption of bases from salts a chemical exchange with the constituents of the soil is necessary," Peters clings to the idea of physical retention; "this [ehemical exchange] is made possible by the help of the great 'predisposing' affinity cxerted by the soil on the bases." "The absorption is conditioned by surface attraction which the molecules of the soil exert."

The generally accepted view thus expressed by Peters was that taught by Justus Liebig, the dominant figure in agricultural chemistry 
in the middle of the nineteenth century, and, indeed, the creator of that branch of science. Soil was known, even before Way's time, to have the power of taking up and holding gaseous ammonia, and this was ascribed by Liebig to mechanical attraction exerted by the soil particles and manifested on their surface.

Rautenberg ${ }^{a}$ in 1862 carried on a series of careful experiments to determine what constituent of the soil was responsible for its absorptive properties, and in the end adopted Way's view that the capacity for absorption depended on certain hydrous silicates. His work was confined to solutions of ammonium compounds. He concludes that in general the bases dissolved are equivalent to the ammonium absorbed, but still recognizes mechanical influences in the absorption.

Küllenberg ${ }^{b}$ three years later published an exhaustive comparison of the effects of various salt solutions through a range of concentrations on a single soil. It will be worth while to reproduce his results here, as they constitute the most systematic investigation of the matter that has been undertaken. An attempt to plot the results as curves reveals occasional inaccuracies of considerable magnitude, but on the whole the data furnish a probably correct outline of existing relationships.

It may be observed again that the base enters into reaction to approximately the same extent whether it is combined as sulphate, chloride, or nitrate. So far as there is a difference, more of the base is removed from sulphate solution than from the others. On comparing chemically equivalent quantities it is seen that ammonium is taken from solution in greatest degree, followed in order by potassium, magnesium, sodium, and calcium. As to the bases dissolved from the soil, Küllenberg's conclusion is that "for the absorbed base nearly equivalent quantities of other bases, already present in the soil, have been carried over into the solution."

Eighteen experiments with sulphates showed no absorption of $\mathrm{SO}_{4}$. Twenty with chlorides showed no absorption of $\mathrm{Cl}$. The significance of this is of course somewhat lessened by the fact that the soil contains both sulphate and chloride.

The composition of the soil is shown on the next page.

a Jour. für Landw., vol. 7, 1862, pp. 405-554; also vol. 7, 1862, pp. 49-66.

$b$ Mitteil. d. landw. Centralvereins für Schlesien, Heft 15, p. 83; also Jahṛb. Fortschr. Agr. Chem., vol. 8,1865, p. 15. 
Composition of soil used in Küllenberg's experiments:

\begin{tabular}{|c|c|c|c|}
\hline Constituent. & $\begin{array}{l}\text { Soluble in } \\
2 \frac{1}{2} \text { parts } \\
\text { cold water. }\end{array}$ & $\begin{array}{l}\text { Soluble in } \\
3 \text { parts } \\
\text { boiling } \\
\text { HCl, spe- } \\
\text { cific grav- } \\
\text { ity, } 1.17 .\end{array}$ & $\begin{array}{c}\text { Insoluble } \\
\text { in boiling } \\
\mathrm{HCl} \text {. }\end{array}$ \\
\hline 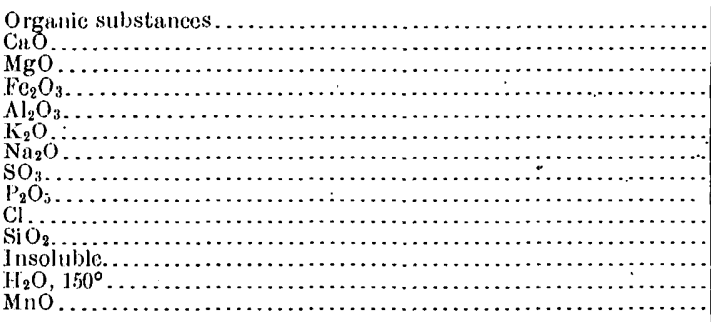 & $\begin{array}{r}0.0116 \\
0.0065 \\
0.0022 \\
0.0045 \\
0.0022 \\
0.0012 \\
0.0027 \\
0.0035 \\
0.0006 \\
0.0055 \\
0.0122 \\
0.0082 \\
\ldots \ldots \ldots \\
\ldots \ldots \ldots\end{array}$ & $\begin{array}{r}2.1380 \\
0.2436 \\
0.2846 \\
1.5912 \\
1.8480 \\
0.1950 \\
0.0612 \\
0.0413 \\
0.0863 \\
0.0059 \\
0.0930 \\
87.9650 \\
5.2840 \\
0.2412\end{array}$ & 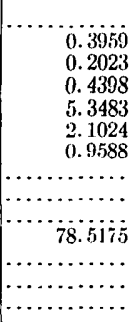 \\
\hline 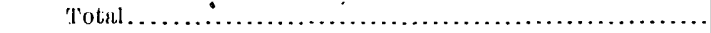 & 0.0609 & 100.08 & 87.97 \\
\hline
\end{tabular}

a Insoluble on evaporating solution and heating residue. Soil contained also 0.0059 per cent $\mathrm{NH}_{8}$ 0.0105 per cent $\mathrm{N}_{2} \mathrm{O}_{5}$, and 0.0673 per cent total nitrogen. No $\mathrm{CO}_{2}$ present.

In these experiments 100 grams of soil were taken in $250 \mathrm{~cm}^{3}$ solution, which was filtered after three days. Grams absorbed $=$ loss in $250 \mathrm{~cm}^{3}$ plus quantity dissolved from soil by $250 \mathrm{~cm}^{3}$ water alone.

Absorption shown by Küllenbcrg's experiments.

$\mathrm{CHO}$

\begin{tabular}{|c|c|c|c|}
\hline \multirow{2}{*}{ Sallt. } & \multirow{2}{*}{$\begin{array}{l}\text { Jquiva- } \\
\text { lents per } \\
\text { liter in } \\
\text { original } \\
\text { solution. }\end{array}$} & \multicolumn{2}{|c|}{$\begin{array}{c}\text { Amount of base } \\
\text { absorbed. }\end{array}$} \\
\hline & & Gram. & $\begin{array}{l}\text { Per cent of } \\
\text { original. }\end{array}$ \\
\hline 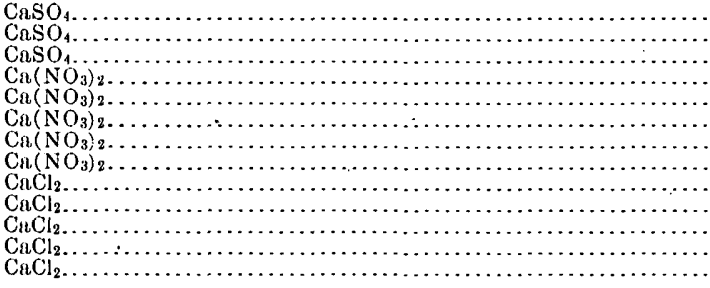 & $\begin{array}{l}0.01 \\
0.02 \\
0.04 \\
0.01 \\
0.02 \\
0.04 \\
0.1 \\
0.2 \\
0.01 \\
0.02 \\
0.04 \\
0.1 \\
0.2\end{array}$ & $\begin{array}{l}0.0173 \\
0.0243 \\
0.0312 \\
0.0066 \\
0.0180 \\
0.0224 \\
0.0257 \\
0.0328 \\
0.0118 \\
0.0208 \\
0.0270 \\
0.0308 \\
0.0374\end{array}$ & $\begin{array}{c}26.0 \\
17.3 \\
11.1 \\
9.8(?) \\
13.5 \\
8.4 \\
3.8 \\
2.4 \\
17.7 \\
15.6 \\
10.2 \\
4.6 \\
2.8\end{array}$ \\
\hline
\end{tabular}

MGO.a

\begin{tabular}{|c|c|c|c|}
\hline 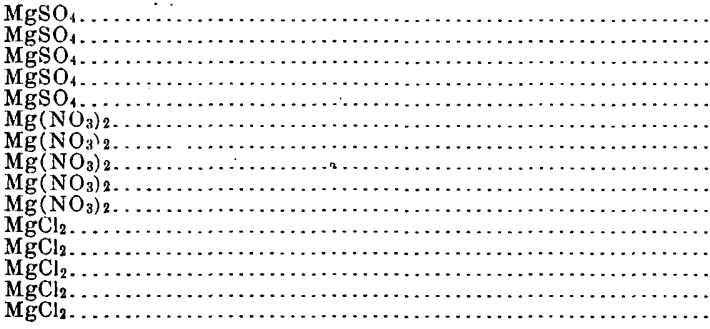 & $\begin{array}{l}0.01 \\
0.02 \\
0.04 \\
0.1 \\
0.2 \\
0.01 \\
0.02 \\
0.04 \\
0.1 \\
0.2 \\
0.01 \\
0.02 \\
0.04 \\
0.1 \\
0.2\end{array}$ & $\begin{array}{l}0.0220 \\
0.0362 \\
0.0479 \\
0.0734 \\
0.1312 \\
0.0238 \\
0.0371 \\
0.0470 \\
0.0731 \\
0.0815 \\
0.0184 \\
0.0346 \\
0.0450 \\
0.0569 \\
0.0985\end{array}$ & $\begin{array}{l}46.4 \\
38.2 \\
25.2 \\
15.5 \\
13.8 \\
50.2 \\
39.1 \\
24.8 \\
15.4 \\
8.6(?) \\
38.8 \\
36.5 \\
23.7 \\
10.2(?) \\
10.4\end{array}$ \\
\hline
\end{tabular}

a Anion of less influence here than with $\mathrm{Ca}$.

Bull. $312-07-2$ 
Absorption shown by Küllenberg's experiments-Continued.

$\mathrm{N}_{\Lambda_{r}} \mathrm{O}$.

\begin{tabular}{|c|c|c|c|}
\hline \multirow{2}{*}{ Salt. } & \multirow{2}{*}{$\begin{array}{l}\text { Fquiva- } \\
\text { lents per } \\
\text { liter in } \\
\text { original } \\
\text { solution. }\end{array}$} & \multicolumn{2}{|c|}{$\begin{array}{c}\text { Amount of base } \\
\text { absorbed. }\end{array}$} \\
\hline & & Gram. & $\begin{array}{l}\text { Per cent of } \\
\text { original. }\end{array}$ \\
\hline 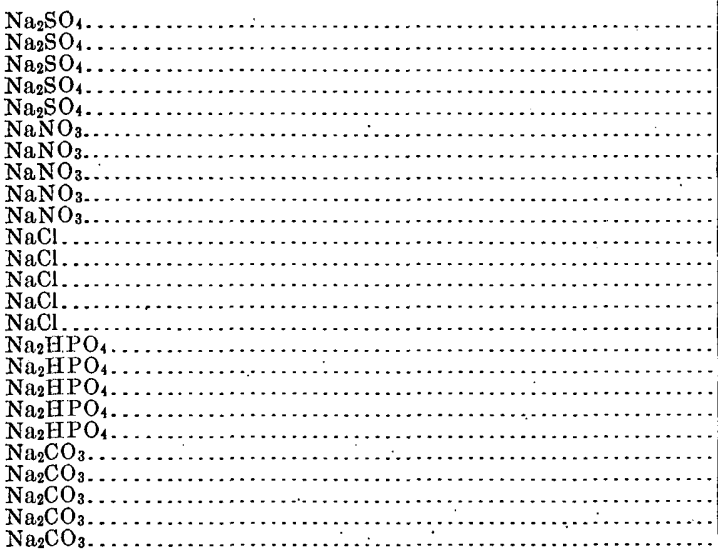 & $\begin{array}{l}0.01 \\
0.02 \\
0.04 \\
0.1 \\
0.2 \\
0.01 \\
0.02 \\
0.04 \\
0.1 \\
0.2 \\
0.01 \\
0.02 \\
0.04 \\
0.1 \\
0.2 \\
0.005 \\
0.01 \\
0.02 \\
0.05 \\
0.1 \\
0.01 \\
0.02 \\
0.04 \\
0.1 \\
0.2\end{array}$ & $\begin{array}{l}0.0140 \\
0.0216 \\
0.0372 \\
0.0849 \\
0.1211 \\
0.0140 \\
0.0228 \\
0.0352 \\
0.0889 \\
0.1460 \\
0.0112 \\
0.0229 \\
0.0463 \\
0.1020 \\
0.1638 \\
0.0220 \\
0.0414 \\
0.0718 \\
0.1567 \\
0.2819 \\
0.0172 \\
0.0348 \\
0.0734 \\
0.1610 \\
0.2055\end{array}$ & $\begin{array}{c}18.9 \\
14.6 \\
12.6 \\
11.5 \\
8.2(?) \\
18.9 \\
15.4 \\
11.9(?) \\
12.6 \\
9.9 \\
15.2 \\
15.4 \\
15.7 \\
13.8 \\
11.1 \\
29.9 \\
28.1 \\
24.3 \\
21.2 \\
19.1 \\
23.3 \\
23.6 \\
24.9 \\
21.8 \\
13.9\end{array}$ \\
\hline
\end{tabular}

$\mathrm{K}_{2} \mathrm{O}$.

\begin{tabular}{|c|c|c|c|}
\hline 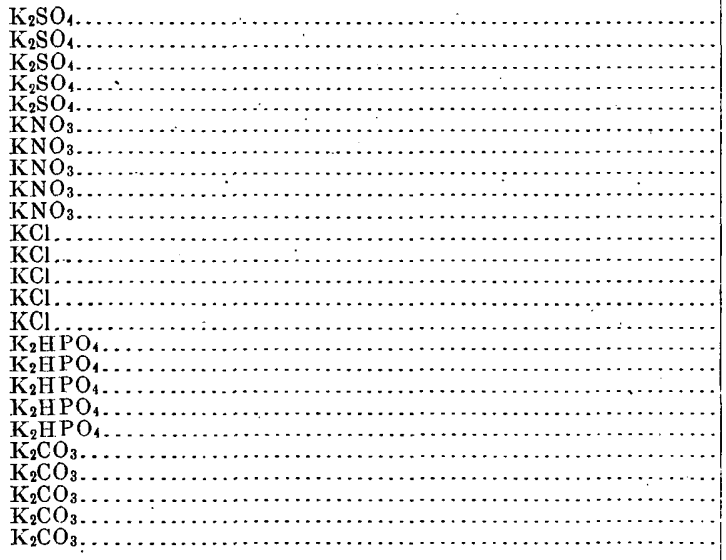 & $\begin{array}{l}0.01 \\
0.02 \\
0.04 \\
0.1 \\
0.2 \\
0.01 \\
0.02 \\
0.04 \\
0.1 \\
0.2 \\
0.01 \\
0.02 \\
0.04 \\
0.1 \\
0.2 \\
0.005 \\
0.01 \\
0.02 \\
0.05 \\
0.1 \\
0.01 \\
0.02 \\
0.04 \\
0.1 \\
0.2\end{array}$ & $\begin{array}{l}0.0609 \\
0.0977 \\
0.1496 \\
0.2360 \\
0.3503 \\
0.0566 \\
0.0840 \\
0.1097 \\
0.1658 \\
0.3072 \\
0.0630 \\
0.0970 \\
0.1084 \\
0.1652 \\
0.2833 \\
0.0713 \\
0.1271 \\
0.2113 \\
0.3295 \\
0.5005 \\
0.0719 \\
0.1989 \\
0.2231 \\
0.3094 \\
0.3747\end{array}$ & $\begin{array}{l}54 . \\
43 . \\
33 . \\
21 . \\
15 . \\
50 . \\
37 . \\
24 . \\
14 . \\
13 . \\
56 . \\
43 . \\
24 . \\
14 . \\
12 . \\
63 . \\
56 . \\
47 . \\
29 . \\
29\end{array}$ \\
\hline
\end{tabular}


Absorption shown by Küllenberg's experiments-Continued.

$\mathrm{NH}_{3}$.

\begin{tabular}{|c|c|c|c|}
\hline \multirow{2}{*}{ Salt. } & \multirow{2}{*}{$\begin{array}{l}\text { Equiva- } \\
\text { lents per } \\
\text { liter in } \\
\text { original } \\
\text { solution. }\end{array}$} & \multicolumn{2}{|c|}{$\begin{array}{l}\text { Amount of base } \\
\text { absorbed. }\end{array}$} \\
\hline & & Gram. & $\begin{array}{l}\text { Per cent of } \\
\text { original. }\end{array}$ \\
\hline$\left(\mathrm{NH}_{4}\right)_{2} \mathrm{SO}_{4}$ & & 0.0290 & \\
\hline$\left(\mathrm{NHF}_{4}\right)_{2} \mathrm{SO}_{4}$ & 0.02 & $0.04 \times 9$ & \\
\hline$\left(\mathrm{NH}_{4}\right)_{2} \mathrm{SO}_{4} \ldots$ & 0.1 & 0.0080 & ${ }_{27.3}^{40.3}-1$ \\
\hline$\left(\mathrm{NH}_{4}\right)_{2} \mathrm{SO}_{4}$. & 0.2 & 0.1400 & 16. 4 \\
\hline $\mathrm{NH}_{4} \mathrm{NO}_{3}$ & 0.01 & 0.0229 & 53.4 \\
\hline $\mathrm{NH}_{1} \mathrm{NO}_{3} .$. & 0.02 & 0.0371 & 43.4 \\
\hline $\mathrm{NH}_{4} \mathrm{NO}_{3} \ldots \ldots$ & 0.04 & 0.0616 & 36.1 \\
\hline $\mathrm{NH}_{4} \mathrm{NO}_{3} \ldots .$. & 0.1 & 0.0871 & 20.4 \\
\hline $\mathrm{NH}_{4} \mathrm{NO}_{3} .$. & $\begin{array}{l}0.2 \\
0.01\end{array}$ & $\begin{array}{l}0.1280 \\
0.0229\end{array}$ & $\begin{array}{l}15.0 \\
53.4\end{array}$ \\
\hline $\mathrm{NH}_{4} \mathrm{Cl}$. & 0.02 & 0.0375 & $\begin{array}{l}44.1 \\
44.1\end{array}$ \\
\hline $\mathrm{NH}_{4} \mathrm{Cl}$. & 0.04 & 0.0612 & 35.9 \\
\hline $\mathrm{NH}_{4} \mathrm{Cl}$. & 0.1 & 0.0811 & 19.0 \\
\hline $\mathrm{NH}_{4} \mathrm{Cl}$. & 0.2 & 0.1174 & 13.8 \\
\hline $\mathrm{NH}_{4} \mathrm{H}_{2} \mathrm{PO}_{4} \ldots$ & 0.01 & 0.0307 & 72.0 \\
\hline & 0.02 & 0.0535 & \\
\hline $\mathrm{NH}_{4} \mathrm{H}_{2} \mathrm{PO}_{4}$ & 0.04 & 0.0919 & \\
\hline & & 0.2000 & $\begin{array}{ll}47.0 \\
38.7\end{array}$ \\
\hline $\mathrm{NH}_{4} \mathrm{H}_{2} \mathrm{PO}_{4} \ldots$ & & 0.3294 & 38.7 \\
\hline $\begin{array}{l}\left(\mathrm{NH}_{4}\right)_{4} \mathrm{H}_{2}\left(\mathrm{CO}_{3}\right)_{3} . \\
(\mathrm{NH})_{4} \mathrm{H}_{2}\end{array}$ & $\begin{array}{l}0.01 \\
0.02\end{array}$ & $\begin{array}{l}0.0260 \\
0.0410\end{array}$ & $\begin{array}{l}61.1 \\
48.1\end{array}$ \\
\hline$\left(\mathrm{NH}_{4}\right)_{4} \mathrm{H}_{2}\left(\mathrm{CO}_{3}\right)_{3}$. & 0.04 & 0.0744 & $\begin{array}{l}40.1 \\
43.7\end{array}-1$ \\
\hline$\left(\mathrm{NH}_{4}\right)_{4}$ & 0.1 & 0.1233 & 28.9 \\
\hline$\left(\mathrm{NH}_{4}\right)_{4} \mathrm{G}$ & & 0.1755 & \\
\hline
\end{tabular}

Warington in $1868^{a}$ studied "The part taken by oxides of iron and aluminum in the absorptive action of soils." He observed a slight decrease on measuring the concentration of potassium nitrate solution before and after contact with ferric hydroxide prepared by precipitation from ferric chloride solution with ammonia.

According to Van Bemmelen ${ }^{b}$ the compounds resulting from such precipitation, commonly called hydroxides, are oxides containing variable amounts of water dependent on the condition as regards moisture of the atmosphere in which they are placed. There is some uncertainty as to what amount of the water of such substances should be counted as hydrate water and not as water diluting the solution. (See p. 24.) Warington assumes as combined water that quantity which is not given off over concentrated sulphuric acid, amounting to 15 per cent. His experiments are not described in sufficient detail to show to what extent this affects the results. With potassium chloride the case was similar, while potassium sulphate underwent greater absorption. As calculated by Warington the ferric oxide took up potassium equivalent to 0.2 per cent of its own weight of $\mathrm{K}_{2} \mathrm{O}$ from potassium nitrate solution; 0.3 per cent from chloride, and 1.2 per cent from sulphate.

Ammonium sulphate or chloride solution became distinotly alkaline - in contact with ferric oxide, a reaction which appears to be analogous to that between mercuric oxide and potassium chloride, etc., where, 
owing to the very slight electrolytic dissociation of mercuric chloride, that compound forms in .quantity, producing at the same time strongly alkaline potassium hydroxide.

Warington found that aluminum oxide was similar in behavior to ferric oxide, although its action was less marked. Rautenberg ${ }^{a}$ had not been able to detect absorption on treating aluminum oxide with ammonium chloride solution.

According to Skey $^{b}$ quartz powder takes iron from ferric acetate solution. This requires verification.

In 1870 Lemberg began the publication of his work on the transformation of silicates by salt solutions. His experiments, whose number runs into the hundreds, constitute a mine of important observations in the chemistry of minerals and of geologic processes. The silicates used were in the main those related to the zeolites, but others were included. The solutions were chiefly of salts of the alkalies and alkaline earths, but embraced also such bases as iron, aluminum, silver, and thallium. The outcome of the experiments was usually either (1) exchange of bases in equivalent quantity between silicate and solution; (2) addition of base to the silicate, especially from alkaline solution; (3) addition of entire salt, or (4) addition or subtraction of water. Frequently, if not usually, transformation to a different mineral species, often crystálline in form, ensued. Most of the work was done at temperatures ranging between $100^{\circ}$ and $200^{\circ}$ C., although some of it was performed at ordinary room temperature. The first papers ${ }^{c}$ contain studies of the action of magnesium salt solutions on such silicates as apophyllite, gehlenite, vesuvianite, datolite, and wollastonite; practically equivalent substitution of magnesium for calcium and potassium took place. The work with wollastonite was conducted at room temperature and also at $100^{\circ} \mathrm{C}$., with the following results:

Action of magnesium sulphate on wollastonite.

\begin{tabular}{|c|c|c|}
\hline & $\mathrm{CaO}$ & MgO. \\
\hline $\begin{array}{l}\text { Wollastonite, original content } \ldots \ldots \ldots \ldots \ldots \ldots \\
\text { Wollastonite after contact with } \mathrm{MgSO}_{4} \text { solution: }\end{array}$ & 44.1 & \\
\hline $\begin{array}{l}\text { Wollastonite after contact with } \mathrm{MgsO}_{4} \text { solution: } \\
\text { Two years at room temperature.................. } \\
\text { Twenty-five days at } 100^{\circ} \mathrm{C} \ldots \ldots \ldots \ldots \ldots \ldots \ldots \ldots\end{array}$ & $\begin{array}{r}27.4 \\
1.0\end{array}$ & $\begin{array}{l}11.5 \\
32.0\end{array}$ \\
\hline
\end{tabular}

The action is the same in the cold as at $100^{\circ}$-an approximately equivalent exchange of calcium for magnesium.

Leucite at high temperatures was converted by sodium chloride solution into analcite, ${ }^{d}$ while potassium chloride effected the reverse

a Jour. für Landw., vol. 7, 1862, p. 422.

$b$ Trans. New Zealand Inst., vol. 2, 1869, p. 151.

c Zeitschr. deutsch. geol. Gesell., vol. 22, 1870, pp. 335 and 803; vol. 24, 1872, p. 187.

d Ibid., vol. 28,1876 , p. 537 . 
transformation. At low temperatures the reaction was likewise an equivalent exchange of bases. The reaction in the cold, although taking place to a less extent, is identical with that which results at higher temperature.

Leucite contains little water, while analcite has 8 or 9 per cent, and all the experiments, hot and cold, show an increase in water content as sodium takes the place of potassium. There seems to be no doubt that the one mineral was changed more or less completely into the other at $200^{\circ} \mathrm{C}$., and the experimental results presented by Lemberg are evidence that the same transformation took place, less rapidly, at $100^{\circ}$, at $40^{\circ}$, and at room temperature. To bring out this point, and also to illustrate the nature of Lemberg's work, the results of his analyses in these experiments will be given in full.

The leucite and analcite were treated with concentrated solutions of the salts designated, and the portions which had undergone transformation were separated by levigation from the unchanged mineral, air-dried, and analyzed. The leucite was from Vesuvius, the analcite from the valley of Fassa.

Action of salt solutions on leucite.

\begin{tabular}{|c|c|c|c|c|c|c|c|}
\hline . & Lencite. & $\mathrm{NaCl}$. & $\mathrm{NaCl}$. & NaCl. & $\mathrm{Na}_{2} \mathrm{CO}_{3}$. & $\mathrm{NaCl}$. & $\mathrm{NaCl}$. \\
\hline $\begin{array}{l}\text { Temperuture (deg. (.)..... } \\
\text { 'Time (months) ............. }\end{array}$ & $\cdots$ & $\begin{array}{l}180-195 \\
(a)\end{array}$ & $\begin{array}{l}100 . \\
4 .\end{array}$ & $\begin{array}{l}100 . \\
1 \frac{1}{2}\end{array}$ & $\begin{array}{c}100 \% \\
4 .\end{array}$ & $\begin{array}{l}40 . \\
11 .\end{array}$ & $\begin{array}{l}\text { Room. } \\
\quad 11 .\end{array}$ \\
\hline 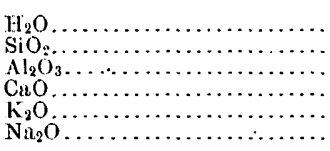 & $\begin{array}{r}0.32 \\
56.04 \\
23.38 \\
0.20 \\
18.90 \\
1.41\end{array}$ & $\begin{array}{r}7.86 \\
55.30 \\
22.91 \\
0.29 \\
0.68 \\
12.90\end{array}$ & $\begin{array}{r}7.84 \\
54.62 \\
23.46 \\
0.20 \\
0.66 \\
13.22\end{array}$ & $\begin{array}{r}8.04 \\
55.38 \\
22.71 \\
0.25 \\
0.89 \\
12.73\end{array}$ & $\begin{array}{r}7.54 \\
54.72 \\
23.61 \\
0.20 \\
1.40 \\
12.54\end{array}$ & $\begin{array}{r}3.40 \\
55.83 \\
.23 .50 \\
0.10 \\
11.61 \\
5.56\end{array}$ & $\begin{array}{r}1.79 \\
55.68 \\
23.48 \\
0.15 \\
15.88 \\
3.02\end{array}$ \\
\hline & 100.25 & 100.00 & 100.00 & 100.00 & 100.01 & 100.00 & 100.00 \\
\hline
\end{tabular}

a 18 hours.

Action of salt solutions on analcite.

\begin{tabular}{|c|c|c|c|c|c|c|}
\hline & Analcite. & $\mathrm{K}_{2} \mathrm{CO}_{3}$ & $\mathrm{~K}_{2} \mathrm{CO}_{3}$ & KCl. & $\mathrm{K}_{2} \mathrm{CO}_{3}$ & $\mathrm{~K}_{2} \mathrm{CO}_{3}$ \\
\hline 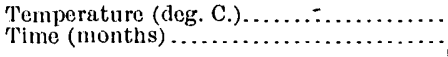 & & 100. & $\begin{array}{l}100 . \\
4 \frac{1}{2} .\end{array}$ & $\begin{array}{l}100 . \\
3 .\end{array}$ & $\begin{array}{ll}40 . \\
7 .\end{array}$ & $\begin{array}{l}\text { Room. } \\
13 \frac{1}{2} .\end{array}$ \\
\hline 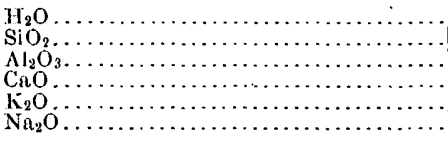 & $\begin{array}{r}8.80 \\
5632 \\
22.00 \\
0.51 \\
73.19\end{array}$ & $\begin{array}{r}0.98 \\
56.03 \\
22.20 \\
0.60 \\
19.60 \\
0.57\end{array}$ & $\begin{array}{r}0.89 \\
55.87 \\
22.29 \\
0.60 \\
20.31\end{array}$ & $\begin{array}{r}0.98 \\
56.38 \\
22.39 \\
0.45 \\
19.80\end{array}$ & $\begin{array}{r}1.23 \\
56.59 \\
21.97 \\
0.52 \\
20.23\end{array}$ & $\begin{array}{r}1.69 \\
56.43 \\
22.62 \\
0.40 \\
17.82 \\
1.04\end{array}$ \\
\hline - & 100.82 & 99.98 & 99.96 & 100.00 & 100.54 & 100.00 \\
\hline
\end{tabular}

Clarke and Steiger, ${ }^{a}$ by heating together dry salts and silicates, obtained, in crystalline form, substitution compounds of ammonium and other bases similar in composition to those here under discussion. 
To throw light on the question of so-called soil absorption, Ler:berg subjected an artificial potassium alumino-silicate to digestion with various salts and salt mixtures in solution and analyzed the resulting solid after thorough washing. Sodium replaced potassium in increasing quantity as the concentration of the sodium chloride solution in contact with the solid was increased. The presence of potassium chloride in the solution at the outset lessened the extent to which substitution of sodium for potassium in the solid took place. Treated with ammonium chloride solution at room temperature, the artificial silicate gave up its potassium almost completely in exchange for ammonium, as did analcite its sodium at $40^{\circ}$ and chabasite and desmin their calcium and sodium at $100^{\circ}$. Similar results followed experiments with other salts. 'The concltsion drawn by Lemberg from his own work and that of others is that "these are purely chemical processes, in which the mass plays a rôle in the sense of Berthollet's theory, hence the incomplete exhaustion of the solution and hence the mutual replacement of the bases."

Lemberg's work brings out over and over again the fact that sodium silicates and alumino-silicates are less stable in contact with water solutions than are the corresponding potassium compounds. Evidence of this is found not only in the laboratory, but also under natural conditions. The replacement of sodium in silicates by the potassium of a dissolved salt takes place far more readily than the reverse reaction. A similar relation, although perhaps not quite so marked, exists between magnesium and calcium silicates. The transformation of a magnesium silicate by calcium chloride into a calcium silicate is more difficult than the reverse change. ${ }^{a}$ Wollastonite, apophyllite, gehlenite, okenite, and a number of artificial magnesium silicates were used to illustrate this experimentally. These phenomena are probably closely related to the relative solubility of the various minerals in water.

Lemberg, ${ }^{b}$ following Bischof, ${ }^{c}$ suggests the possibility that the need of plant life for potassium rather than sodium may be due to the fact that the potassium of silicates is held more tenaciously than the sodium, and accordingly the plant finds more of the potassium at its disposal in the soil; the environment has then developed the habit.

In this same connection we have a suggestion of one reason why the ocean is a solution of sodium rather than potassium chloride. Other metals and other bases have been eliminated owing to their greater capacity than the alkalies for forming compounds insoluble 
in water, or, as in the case of nitrates, to the fact that they are readily decomposed in contact with other substances. The final persistence of the sodium salt rather than that of potassium may be due in large measure to this selective action of silicates in rocks, sediments such as mud, etc.

Lemberg was unable to detect transformation of the feldspars experimentally. "In addition to these (the zeolites) I have experimented with the various feldspars, hornblende, cordierite; serpentine, and scapolite, but up to the present only in the case of hornblende could an exchange of substance be proved with certainty." a

Work along the same line as that of Lemberg was continued by Thugutt. ${ }^{b}$

J. M. Van Bemmelen; of Leiden, in 1877 made an important contribution $^{c}$ to our subject, the first of an extended series by the same author. After a very comprehensive review of the work accomplished up to that date, he describes his own experiments.

One hundred grams of soil were brought into contact with 200 $\mathrm{cm}^{3}$ portions of solution containing respectively $S$ and 40 milligram-equivalents of potassium chloride. After filtration the solutions were carefully analyzed, with the following results, expressed in milligram-equivalents. The author estimates the experimental error of a determination as at most \pm 0.2 :

Results of Van Bemmelen's experiments with potassium chloride.

\begin{tabular}{|c|c|c|c|}
\hline \multirow{2}{*}{$\therefore$} & \multicolumn{2}{|c|}{$\begin{array}{l}8 \mathrm{mg} \text {. equivalents } \\
\text { in } 200 \mathrm{~cm}^{3} \text {. }\end{array}$} & \multirow{2}{*}{$\begin{array}{c}40 \mathrm{mg} . \\
\text { equiva- } \\
\text { lents in } \\
200 \mathrm{~cm}^{3} . \\
\text { Experi- } \\
\text { ment III. }\end{array}$} \\
\hline & $\begin{array}{l}\text { Experi- } \\
\text { ment I. }\end{array}$ & $\begin{array}{l}\text { Experi- } \\
\text { ment II. }\end{array}$ & \\
\hline 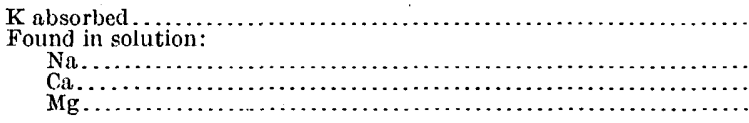 & $\begin{array}{l}6.07 \\
5.58 \\
1.10 \\
1.21\end{array}$ & $\begin{array}{l}5.96 \\
5.50 \\
1.05 \\
1.32\end{array}$ & $\begin{array}{r}15.50 \\
7.34 \\
3.70 \\
6.48\end{array}$ \\
\hline 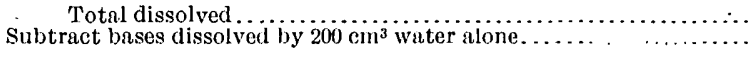 & $\begin{array}{l}7.89 \\
1.50\end{array}$ & $\begin{array}{l}7.87 \\
1.50\end{array}$ & $\begin{array}{r}17.52 \\
1.50\end{array}$ \\
\hline & 6.39 & 6.37 & 16.02 \\
\hline Discrepancy (excess dissolved over absorbed) .... & 0.32 & 0.41 & 0.52 \\
\hline
\end{tabular}

An exchange of potassium for sodium, calcium, and magnesium had taken place. The chlorine also was determined in the first experiment; it had not changed (8.19 equivalents found, instead of 8.0). The author remarks that the result does not show absorption of the salt as a whole; "it can be but very slight, if it takes place at all."

a Zeitschr. deutsch. geol. Gesell.; vol. 28, 1876, p. 591.

$\checkmark$ Dissertation, Dorpat, 1891, and Zeitschr für anorg. Chemie, vol. 2, 1892, pp. 64-156.

c Landwirtschaftliche Vers. Stat., vol. 21, 1877, pp. 135-191. 
Van Bemmelen later ${ }^{a}$ investigated the behavior of hydrous silica toward various solutions. The silica used, although containing water in an amount represented by the formula $\mathrm{SiO}_{2}, 4 \mathrm{H}_{2} \mathrm{O}$, of which 3.8 $\mathrm{H}_{2} \mathrm{O}$ was given off on drying at $100^{\circ} \mathrm{C}$. or: over concentrated sulphuric acid, was a dusty powder. The result of putting this substance into salt solutions was practically the same as if the loosely bound water of the silica had been added as liquid. The solute distributed itself almost uniformly between the water of the solution and the water of the colloid.

The quantities taken for experiment were $100 \mathrm{~cm}^{3}$ of solution and 10 grams of silica. The 3.8 molecules of water loosely held by the silica amount to $5.18 \mathrm{~cm}^{3}$ in 10 grams of the powder, and in case this acts as solvent water the concentration would be that corresponding to dilution to $105.18 \mathrm{~cm}^{3}$. The solutions, analyzed after contact with the solid, were actually of concentrations corresponding to dilution to the following volumes:

- Results of Van Bemmelen's experiments wilh hydrous silica, showing volumes corresponding to observed concentration.

\begin{tabular}{|c|c|c|c|}
\hline • & 1. & 2. & 3. \\
\hline Fquivalents $a$ origintelly in $100 \mathrm{~cm}^{3} . \ldots \ldots$ & 20 & 50 & 100 \\
\hline 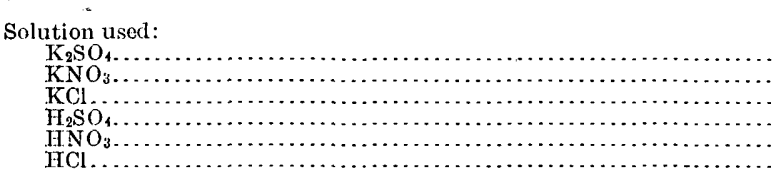 & $\begin{array}{r}C n^{3} . \\
105.3 \\
104.7 \\
104.4 \\
105.8 \\
104.4 \\
104.2\end{array}$ & $\begin{array}{l}C m^{3} . \\
105.2 \\
104.4 \\
104.5 \\
104.5 \\
104.5 \\
104.7\end{array}$ & $\begin{array}{r}C m^{3} . \\
104.8 \\
\cdots \cdots . . . \\
104.2 \\
104.2 \\
104.3\end{array}$ \\
\hline
\end{tabular}

$a$ As used by Van Bemmelen, equivalent, atom, and molecnle signify the respective weights taken in milligrams.

How much of the water of the solid is to be counted as taking up the solute and how much of it is in a condition in which it will not act as solution water can not, according to Van Bemmelen, ${ }^{b}$ be determined; the assumption that 3.8 molecules perform that function may therefore be subject to modification. In the experiments just cited somewhat less salt was, as a rule, absorbed by the silica than this assumption would require. Van Bemmelen is inclined to regard the action as an exchange between colloid and solution; the colloid taking up salt and giving off an equivalent quantity of water.

In a later paper ${ }^{c}$ speaking of absorption by the soil, Van Bemmelen says: "If absorption of the entire salt takes place it is slight, and in any case not greater than with silica." A certain soil after removal of all matter soluble in hydrochloric acid and drying at $110^{\circ}$

a Jour. für prakt. Chemie, vol. 23,1881 , p. 327 ; also Iand. Vers. Stat., vol. 23,1579 , p. 264. $b$ Zeitschr. für anorg. Chemic, vol. 23, 1900, p. 330, and other volumes of the sime journal.

$c$ Landw. Vers. Stat., vol. 35,1888, p. 121. 
took up 12.8 per cent moisture from moist air. "The water thus absorbed plays the same part, so far as the salt is concerned, as the water of the solution." Contact with this soil dried at $110^{\circ}$ did not alter the concentration of chlorine in a potassium chloride solution; the concentration before contact was 20.13 milligram-equivalents in $100 \mathrm{~cm}^{3}$; after contact it was 20.18. Therefore the dried powdered material did not.extract water as such from the solution; had it done so the concentration of the solution would have increased about 5 per cent. The salt is, as in the case of the silica, uniformly distributed between the water of the solution and any water taken up by the solid. There is no absorption of the salt alone, although there may be absorption of the unchanged solution. The same soil, containing 12.8 per cent moisture, decreased the chlorine concentration to the same extent as would the water it contained if added as liquid to the solution. In his summing up at the conclusion of this paper Van Bemmelen says: "The absorption phenomena of the soil are to be ascribed chiefly to colloid silicates, whose power of absorption for entire salts is slight (ein geringes)."

As late as 1900 Van Bemmelen writes: "As to a specific absorption, these complexes (colloid silicates) exert none or almost none; if salts are absorbed, the absorbed water is the chief cause therefor."

The important practical fact here is that colloid silica and colloid silicates as they occur in nature do not possess in any large measure the power of abstracting from solution and concentrating neutral salts. Water percolating through such material will share its dissolved salts with the water of the colloid; but there can be no notable accumulation of salt except as it is present in corresponding quantity in the solution both before and after contact with the siliceous matter.

A paper published by Lagergren in $1899^{\circ}$ on the "Theory of the. so-called adsorption of dissolved substances," describes experiments on the action of animal charcoal, kaolin, and powdered glass on the dissolved salts of the alkalies, barium, and magnesium. The author found that charcoal and kaolin dried at $160^{\circ} \mathrm{C}$. increased the concentration of chlorides and bromides, in some cases as much as 1 per cent; the concentration was determined by specific gravity and by titration with silver nitrate. The data given do not show how well these methods agreed. The charcoal and kaolin had been boiled-with hydrochloric acid in order to purify them. In the case of the sulphates specific gravity alone was relied upon for the determination of concentration. The charcoal contained considerable mineral matter. In view of the importance of the matter, confirmation of Lagergren's results seems desirable.

a 7eitschr. anorg. Chemie, vol. 23, p. 321.

$b$ Bihang till k. Svenska Vet.-Akad. Fandlingar, Bd. 24, Afd. II, No. 4, 1899. 
Joly $^{a}$ showed that sea water attacks basalt, orthoclase, obsidian, and hornblende to a much greater extent than does fresh water.

Dittrich ${ }^{b}$ found that the action of salt solutions on a decomposed. hornblende granite consisted in an exchange of bases. Neutral potassium chloride solution dissolved from the rock almost twice as much calcium as dilute acetic acid, and about one-fourth as much as warm 10 per cent hydrochloric acid. Neither carbonic nor acetic acid dissolved more than a small part of the potassium taken from solution by the rock powder. Potassium, ammonium, and magnesium chlorides had approximately equal effect on the powdered granite, while the action of sodium chloride was much weaker, and calcium chloride scarcely produced any change whatever. The action was the same whatever the acid with which the base was combined.

Powdered feldspar or kaolin with potassium chloride solution gave but little action. "Beide Versuche hatten also ein negatives Resultat gegeben." The experiments did show, however, that simple absorption of the potassium had not taken place.

Laterite and bauxite with potassium chloride solution retained but small quantities of potassium, which, in contrast to that taken up by silicates, was almost completely redissolved by water. A slight exchange also took place between the calcium of the solid and the potassium of the salt. In one experiment with laterite $0.0048 \mathrm{gram} \mathrm{CaO}$ and a trace of magnesium oxide went into solution, while potassium equivalent to 0.0298 gram potassium oxide, out of a total of 0.4680 gram, was taken up by the 25 grams of the solid. "These experiments prove most clearly that the phenomena under investigation are not absorption phenomena, but are purely chemical processes." Hydrous aluminates of calcium and magnesium the author considers responsible for the absorption of potassium in the earth's crust.

As affording definite data regarding the substances dissolved from a rock of the character mentioned, a part of Dittrich's results will be reproduced in detail. The decomposed rock contained 0.90 per cent calcium oxide, 1.50 per cent magnesium oxide, 7.73 per cent potassium oxide, 1.72 per cent sodium oxide; 25 grams rock powder were taken in each instance with $100 \mathrm{~cm}^{3}$ salt solution.

Quaniilies, in grams, dissolved from rock, by $\mathrm{N} / 10 \mathrm{NaCl}\left(0.5806\right.$ gram in $\left.100 \mathrm{~cm}^{3}\right)$.

$\mathrm{CaO}$.

0.0356

$\mathrm{MgO}$

0.0050

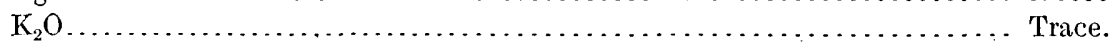

About one-eighth of the total sodium was removed from solution by the rock. The total bases in the solution are equivalent to 0.5981 . 
gram $\mathrm{NaCl}$, an excess of 0.0175 gram over that originally present. This excess is for the most part accounted for by the solubility of the rock constituents in water alone. ${ }^{a}$ Chlorine, 0.3493 ; originally 0.3518 gram.

Qucintilies, in grams, dissolved from rock by $\mathrm{N} / 10 \mathrm{KCl}\left(0.7404\right.$ gram, in $\left.100 \mathrm{~cm}^{3}\right)$.

$\mathrm{CaO}$

0.0640

$\mathrm{MgO}$

0.0056

$\mathrm{Na}_{2} \mathrm{O}$

0.0169

About two-sevenths of the potassium was precipitated. The total bases in solution were equivalent to 0.7600 gram $\mathrm{KCl}$, greater by 0.0196 gram than the original amount. Chlorine 0.3468 ; originally 0.3518 .

$\mathrm{N} / 10 \mathrm{MgCl}_{2}\left(0.4750\right.$ gram in $\left.100 \mathrm{~cm}^{3}\right)$ gave $0.0630 \mathrm{CaO}$ and small quantities of $\mathrm{K}_{2} \mathrm{O}$ and $\mathrm{Na}_{2} \mathrm{O}$. About one-fifth of the magnesium was precipitated. Iime and magnesia in solution were equivalent to 0.4888 gram magnesium chloride, an excess of 0.0138 gram over that originally present.

Alkali nitrates, sulphates, and carbonates gave similar results. Calcium chloride had little effect. Dittrich continued this work and published its results. ${ }^{b}$

Briggs ${ }^{c}$ investigated the action of dilute solutions on powdered quartz whose particles were for the most part 0.005 to 0.05 millimeter in diameter, corresponding to a total area of about $1,000 \mathrm{~cm}^{2}$ per gram.

No change in the concentration of neutral salts could be detected after contact of their solutions with quartz, and the author's conclusion is that "so far as quartz is concerned adsorption is of minor" importance in the retention of soluble substances in the soil."

Cushman, in the microscopic appearance of the particles and in the formation of a considerable quantity of soluble alkali silicate on wet grinding, found experimental evidence that water produces a colloidal siliceous film on the surface of powdered orthoclase and other silicates. $^{d}$

So far as the evidence goes, then, the action of silicates, clay, and other constituents of the earth's crust on solutions of such salts as do not dissolve in water with alkaline reaction consists in an equivalent exchange of bases. The salt is uniformly distributed between the water of colloid silica and silicates and the water of the solution. Any absorption of the salt as a whole by the solids mentioned is so slight as to have escaped positive detection. As bearing on the latter point it should be said that certain colloid substances, analogues to which are present in the earth's crust, do take from solution both the 
acid and the base of the salts mentioned. Ferric and aluminum oxides and metastannic and stannic acids, for instance, take potassium sulphate from solution, while hydrated manganese dioxide takes up sulphate, chloride, or nitrate of potassium. ${ }^{a}$ This of course does not necessarily imply adsorption. It is not at all impossible, as Van Bemmelen suggests, that chemical reaction takes place. Manganese dioxide takes up more base than acid from a neutral salt solution, and thus imparts to the solution acid reaction. Cupric oxide takes more of the acid and alkalinity of solution results. ${ }^{b}$. These and other similar reactions suggest the reaction between mercuric oxide and potassium chloride, where potassium hydroxide forms owing to the slight electrolytic dissociation of mercuric chloride, and they may be due to similar causes. The solids capable of absorbing both acid and base from a neutral salt solution are in the main those which them-. selves exercise both basic and acidic functions.

It is interesting that Van Bemmelen, about six years before the propounding of Arrhenius's theory, uses the old electrolytic dissociation theory of Clausius to interpret these reactions: "If we assume with the physicists (as in the explanation of electrolysis) that in a dilute acid or salt solution a few individual molecules are in a state of dissociation, it is conceivable that the potash of these molecules is bound by the manganese dioxide, whereupon fresh dissociation and binding of potash can take place until equilibrium sets in." $c$

\section{ALKALINE SOLUTION.}

Where the solution is alkaline in reaction, containing a soluble hydroxide dissolved as such or a salt made up of a strong base and a weak acid (as the carbonates, silicates, and phosphates of sodium and potassium) which is hydrolyzed by water with resulting formation of free alkali, its behavior with clay, soils, etc., is due largely to the presence of colloid silica or aluminum silicate, and consists primarily in the direct addition of alkali to these solids, without substitution, insoluble silicates or alumino-silicates being formed.

Way $^{d}$ was the first to observe that the absorption of free alkali (potassium hydroxide) by clay was greater after the clay had been extracted by hot hydrochloric acid. $\mathrm{He}$, however, attached little importance to the observation. The same fact was noted by Van Bemmelen $^{c}$ and attributed to the union of the alkali with silicic acid remaining after decomposition of silicates by the hydrochloric acid: That free alkali was taken from solution by soils without substitution by other bases was observed by Henneberg and Stohmann $f$ in the

a Van Bemmelen, Jour. für prakt. Chemie, vol. 131, 1\$81, p. 330.

$b$ 'Tommasi, Comptes rendus, vol. 92, p. 453.

c Loc. cit., p. 394.

a Jour. Roy. Agr. Soc., vol. 11, 1850, p. 359.

$e$ Landw. Vers.-Stat., vol. 21, 1877.

f Ann. Chem., vol. 107, 1\$58, p. 152; Jour. für Landw., vol. 3, 1859, p. 25. 
case of ammonia, and later by others in the case of other bases. That the extraction with acid by decomposing soluble silicates or coating them with an impervious layer of silicic acid in large measure destroys the power of absorption with substitution was shown by Peters, ${ }^{a}$ Eichhorn, ${ }^{b}$ and others.

The fact that silicates after extraction with acid are capable of taking up free alkali led Heiden ${ }^{c}$ to an astonishing observation. In order to remove silica after extraction with acid he digested with sodium carbonate solution and was surprised to find that the residue took up $3 \frac{1}{2}$ times as much potassium from potassium chloride solution as before the sodium carbonate treatment. Sodium had been taken up by the silica, and this was then in a position to enter into exchange with potassium in neutral solution.

The decrease in concentration observed by Briggs ${ }^{d}$ on treating potassium, sodium, and ammonium hydroxide solutions with quartz (100 grams quartz powder, $150 \mathrm{~cm}^{3}$ solution) in glass flasks was approximately the same in the three cases.

Absorption of alkali by quartz.

\begin{tabular}{|c|c|c|}
\hline & Final concentration. & $\begin{array}{l}\text { Loss, } 150 \\
\mathrm{~cm}^{3} \text {. }\end{array}$ \\
\hline $\begin{array}{l}0.105 \text { millimol in } 150 \mathrm{~cm} \\
13 \text { millimols in } 150 \mathrm{~cm}^{3} .\end{array}$ & $\begin{array}{l}. . \\
.\end{array}$ & $\begin{array}{c}\text { Millimol. } \\
0.042 \\
0.8\end{array}$ \\
\hline
\end{tabular}

Carbonates suffered a slighter loss in concentration under similar conditions. That this action was due chiefly to the glass of the flask rather than to the quartz was shown by the fact that the results with potassium hydroxide in a platinum container were only about onesixth those in glass.

The author recognizes that "the carbonate and hydroxide can not be considered free from chemical action on the quartz."

Rümpler ${ }^{c}$ discusses these reactions in connection with the fact that sugar-makers purify beet juices by filtration through a silicate (an artificial cement) which takes out practically all of the potassium and about 25 per cent of the nitrogenous bases (betain), thus leaving the molasses less viscous and capable of further crystallization. $\mathrm{He}$ points out that when free alkali (potassium hydroxide) acts on a silicate the calcium and magnesium, which are removed are at once precipitated as hydroxides and therefore do not tend to put a stop to further substitution of potassium by promoting the reverse reaction, as their. soluble salts would do. This is suggested as a reason why free alkali has greater. action on silicates than a neutral salt has.

$a$ Landw. Vers.-Stat., vol. 2, 1860, p. 146.

$b$ Jahrb. Fortschr. Agr. Chem., vol. 2, 1859, p. 16.

c.Düngerlehre, vol. 1, p. 257; cited by Lemberg.

d Jour. Phys. Chem., vol. 9, 1905, p. 617 .

e Ber. int. Cong. angew. Chemie, 1903, vol. 3, p. 59; also Die deutsche. Zucker-Industrie, vol. 26, 1901, pp. 585 and 625 . 
PRECIPITATION OF ACID ION.

The loss of the acid radical of a dissolved salt to clay, soil, etc., appears, like the loss of the base, to be due usually to the formation of an ordinary insoluble salt, such as the phosphate, carbonate, or silicate of calcium, iron, etc. Such precipitation takes place primarily from alkaline solution because the acids that have the greatest tendency to form insoluble compounds are weak acids, whose salts are hydrolyzed by water. It is observed also in such solutions as those obtained by dissolving calcium carbonate or calcium phosphate in carbonic acid solution.

Way ${ }^{a}$ notes the fact that the acids of ammonium carbonate, potassium carbonate, calcium bicarbonate, sodium phosphate, calcium acid phosphate, etc., are removed from solution by soils, together with the bases.' Now the base of the dissolved salt in contact with these soils is substituted chiefly by calcium. When the calcium salt is soluble, therefore, as in the case of the chloride, nitrate, and sulphate, the acid radical remains in the solution; when the calcium salt is insoluble, as in the case of the carbonate or phosphate, the acid radical is precipitated.

Liebig ${ }^{b}$ showed that the acid radical of sodium and potassium silicates was removed in part by soils. According to Küllenberg ${ }^{c}$ the phosphate radical is taken up by soil from solution in greater quantity the higher the atomic weight of the metal with which it is combined (potassium, sodium, ammonium). The difference is probably due to the varying readiness with which the salts of the different metals decompose the silicates of the soil.

Warington ${ }^{d}$ attributes the removal of the phosphate radical from solution by soils chiefly to interaction. with ferric and aluminum oxides with formation of insoluble phosphates. He shows that the oxides mentioned when artificially prepared are changed to phosphates by a solution of calcium phosphate in water containing carbonic acid. Ferric oxide (moist, prepared by precipitation from ferric chloride solution with ammonia) takes up about 6 per cent of its weight of potash $\left(\mathrm{K}_{2} \mathrm{O}\right)$ from a 1 per cent solution of potassium carbonate. From 0.4 to 0.8 equivalent of the carbonate radical is absorbed for one of potassium. By the same oxide 2.3 per cent of potassium sulphate is taken up, 6 per cent of ammonium carbonate (equivalent quantities of base and acid), 2.5 per cent of ammonium sulphate, and 0.24 per cent of ammonium chloride, a 1 per cent solution of the salt being used in each case. The ammonium salt solutions are distinctly alkaline after contact with ferric oxide. Aluminum oxide gives results similar to those with ferric oxide, but less strongly marked.

a Jour. Roy. Agr. Soc. vol. 11, 1850, loc. cit.

$b$ Ann. Chemie, vol. 105, 1858, p. 109. c Jahrb. Fortschr. Agr. Chem., vol. 8, 1865, p. 15. dJour. Chem. Soc. London, vol. 21, 1868, p. 1. 
Van Bemmelen ${ }^{a}$ showed that extraction with hydrochloric acid, which dissolved oxides of iron and aluminum and decomposed silicates to such an "extent that absorption with substitution would not take place, also did away with precipitation of the carbonate, phosphate, and borate radicals by the soil. A soil thus extracted took up half the alkali from sodium carbonate solution, leaving the acid radical. in its entirety as bicarbonate. From a solution of sodium phosphate $\left(\mathrm{Na}_{2} \mathrm{HPO}_{4}\right)$ such a soil took up 7.6 equivalents sodium out of a total of 38.8 present, leaving the acid radical practically unchanged. From a borax solution it took 5 equivalents sodium out of a total of 9 , and no boron. The same soil before extraction with hydrochloric acid took 12 equivalents of sodium and 4.6 milligram-atoms of phosphorus from a sodium-phosphate solution containing 38.8 equivalents of sodium and 19.4 mill.gram-atoms of phosphorus.

These facts are in harmony with the conclusion above stated-that the abstraction of acid radical from solution by silicates is due to the formation of insoluble salts, the basic constituents capable of forming these insoluble salts being removed or rendered inaccessible to the solution by the action of hydrochloric acid.

\section{INFLUENCE OF CALCIUM CARBONATE.}

The action of such silicic acids as result from extraction of a silicate or a soil with acid, as in the experiments of Van Bemmelen just cited, is of some practical importance where calcium carbonate is present, giving to the mixture an alkaline reaction. In such a case, as has been shown, the free alkali unites with the silicic acid and is thus precipitated. The consequence of this is that more calcium carbonate dissolves to replace the calcium hydroxide removed, and these processes repeat themselves until equilibrium is reached. The extent to which the solubility of calcium carbonate is increased by the presence of a soil which has been extracted with hydrochloric acid is shown by the following data from Van Bemmelen. " "Soil B" designates the soil extracted with hydrochloric acid.

$250 \mathrm{~cm}^{3}$ water dissolve 0.30 milligram-equivalent calcium carbonate.

$250 \mathrm{~cm}^{3}$ water in the presence of 100 grams soil B dissolved 2.4 milligram-equivalents.

"Soil B" in contact with calcium carbonate not only thus increases the amount of the latter which may be held in solution by a water, but it becomes itself capable, through the medium of the calcium carbonate, of reaction with neutral salts. Again citing Van Bemmelen, ${ }^{c}$ $250 \mathrm{~cm}^{3}$ potassium chloride solution (50 equivalents) dissolve 0.73 equivalent calcium carbonate. But in the presence of 100 grams of soil $\mathrm{B}, 250 \mathrm{~cm}^{2}$ of the same solution dissolve from calcium carbonate

$a$ Landw. Vers.-Stat., vol. 23, 1879, p. 267. b Landw. Vers.-Stat., vol. 23, 1879, p. $273 . \quad c$ Loc. cit. 
6.2 equivalents of calcium and 4.2 of the carbonate radical, while 4 equivalents of potassium are taken up by the soil owing to partial double decomposition between calcium hydroxide and potassium chloride with resultant formation of potassium hydroxide, which combines with the silicic acid.

In similar experiments with amorphous silica containing water corresponding approximately to the formula $\mathrm{SiO}_{2}, 4 \mathrm{H}_{2} \mathrm{O}$, calcium carbonate alone was but little affected by the silica, and potassiun chloride solution not at all, but when 20 grams silica, 2 grams calcium carbonate, and $200 \mathrm{~cm}^{3}$ (40 equivalents) potassium chloride solution were mixed it was found that 3.8 milli-equivalents of calcium and 2.7 of the carbonate radical were dissolved and 2 of potassium were - taken up by the silica.

Lemberg had somewhat earlier ${ }^{a}$ brought out experimentally the same point with regard to the influence of calcium carbonate. $\mathrm{He}$ used carbonic acid solution for extracting the alkali from an artificial zeolite-like potassium alumino-silicate, ${ }^{b}$ and the behavior of the resultant silicic acids toward calcium carbonate and neutral salt solutions was similar to that of Van Bemmelen's soil B, which had been extracted with hydrochloric acid. Lemberg's discussion of this reaction is well worth reproducing: ${ }^{c}$

These experiments show what essentially different courses chemical-geological transformations may take, according to the electro-negative constituent of the salt solution which causes the metamorphism. Consider a carnallite bed underlain by layers of clay, and suppose the clay to be transformed in places into some product rich in potash, such as a mica. It is natural to attribute the potasin content of the metamorphic product to the overlying carnallite; the fact remains unaccounted for, however, that the entire body of clay has not undergone the same change. The matter is thrown into a very different light when it is found that the altered portions of the clay carry calcium carbonate, while the surrounding portions are free from it. If the clay possesses a composition similar to that of the silicate extracted with carbonic acid in the experiments described, the percolating potassium chloride solution will be without action on it; contact of the solution with calcium carbonate, however, will cause partial change into calcium chloride and potassium carbonate, and the latter salt, being alkaline, is capable of changing the clay into a potash silicate. As the altered clay has taken up no calcium one would scarcely be likely to connect the mechanically admixed calcium carbonate with the metamorphism, and yet it has been the conditio sine qua non; still more difficult to clear up would the process be if the calcium carbonate had been completely dissolved out and the last clue thus destroyed.

As the transformation of this clay is conditioned by the calcium carbonate, so, on the other hand, the solubility or alterability of the calcium carbonate is affected by the presence of the clay. Of two marls, one a clay capable of taking up alkali and the other a chloritic clay, the former, other things being equal, will in a fixed time give up more lime in the form of calcium chloride to waters containing sodium and potassium chlorides than the latter.

a Zeitschr. deutsch. geol. Gesell., vol. 28, 1876, p. 593.

$b$ O riginal $\mathrm{K}_{2} \mathrm{O}$ content, 22.8 per cent; after extraction with $\mathrm{CO}_{2}, 5.3$ per cent.

c Loc. cit., p. 594. 
Such modifications of one chemical process by another may be of frequent occurrence, and the striking fact that rock masses apparently perfectly homogeneous suffer at points but little apart very different transformations, loses in a measure its puzzling character in view of the above considerations.

\section{APPLICATION OF MASS LAW.}

A paper by H. P. Armsby, written in $1877,{ }^{a}$ contributed toward a clear understanding of the nature of the absorption of bases by silicates. Way and other workers on the subject had been embarrassed in attempting to classify the observed phenomena as chemical reactions by the fact that no relation of chemical equivalence existed between the quantity of base taken up and the quantity of any single constituent or of any group of constituents of a soil present under the conditions of the experiment. Nor could such a relation be found among the quantities of different bases taken up by a fixed amount of one soil. Even among compounds of the same base the absorption from a solution of the hydroxide or salt alkaline in reaction was not as a rule the same as from solutions of the neutral salts. Further, the absorption of base by a given soil from the same salt was by no means invariably the same, but fluctuated with temperature, concentration of the solution, and relative quantities of soil and solution. These facts were used as arguments in favor of the theory that absorption was a physical surface phenomenon.

All these things, Armsby points out, are in accordance. with the law of mass action. The absorption had been shown to be an exchange of bases between the silicates of the soil and the dissolved salts. In the specific case which he takes up experimentally--the reaction between calcium chloride and an artificial sodium aluminosilicate-there is opportunity for the formation of two slightly soluble substances, one the sodium alumino-silicate, the other the corresponding calcium compound. In such a case reaction in general does not proceed to the formation of one of the two substances exclusively to the absolute wiping out of the other, but an equilibrium condition is reached in which both slightly soluble compounds are present. When such equilibrium sets in a definite relation prevails among the concentrations of the reacting substances in the solution. When calcium chloride solution, for example, is brought into contact with solid sodium alumino-silicate equilibrium may require sodium in solution in excess of calcium. In such case solid calcium aluminoșilicate will form, withdrawing calcium from and supplying sodium to the solution until the necessary ratio is reached. The amount of solid transformed will therefore vary with the amount and concentration of the solution used as well as with the nature of the solute. Sodium chloride in this case accumulates in the solution until its 
tendency to react with the newly formed calcium alumino-silicate, producing again the original substances, holds in check the tendency of the first reaction to take place.

In illustration of this Armsby shows that the absorption of calcium falls off when sodium chloride is present in the solution from the beginning with calcium chloride:

Absorption of calcium by silicate, in grams.

\begin{tabular}{|c|c|c|}
\hline $\begin{array}{c}\text { Amount of } \\
\text { silicate } \\
\text { taken. }\end{array}$ & $\begin{array}{c}\text { Absorp- } \\
\text { tion, NaCl } \\
\text { present. }\end{array}$ & $\begin{array}{c}\text { Absorp- } \\
\text { tion, NaCl } \\
\text { absent. }\end{array}$ \\
\hline 2.5 & 0.1151 & 0.1039 \\
1.25 & 0.0663 & 0.0585 \\
0.625 & 0.0359 & 0.0303 \\
0.3125 & 0.0187 & 0.0143 \\
\hline
\end{tabular}

The sodium chloride was added in quantity about equivalent to the calcium chloride.

The amounts of different bases absorbed will vary with the solubility of their respective alumino-silicates and change in temperature, by shifting the relative solubility, may lead to readjustments in the equilibrium.

In the transformation of analcite into leucite by potassium chloride ${ }^{a}$ change of one solid into the other may be expected to take place until the composition of the solution is such that it acts upon neither analcite nor leucite. The simplest case of such a solution is that which results when a mixture of analcite and leucite is treated with water, forming a solution saturated with respect to both solids. The ratio of potassium to sodium in this solution gives at least a qualitative indication of what may be expected for the equilibrium ratio where potassium and sodium salts are in contact with the two minerals.

Leucite, the potassium compound, appears to be less soluble than analcite. It may then be expected that any solution in equilibrium with the two will contain less potassium than sodium and that in solutions not fulfilling this condition transformation of the one solid into the other will take place until this equilibrium condition is satisfied. A potassium salt will therefore transform more of analcite than a sodium salt will of leucite under similar conditions.

\section{INFLUENCE OF CONCENTRATION.}

Bödeker in $1859^{b}$ sought a numerical expression for the relation between concentration of solution and amount of absorption. It was known that increased reaction followed rise in concentration, although not in the same proportion. Bödeker concluded that the absorption was proportional to the square root of the concentration, 
a statement which expresses the facts approximately in some cases, but which has been found not to hold in general. Within certain limits of concentration- 50 to 500 milli-equivalents salt per liter-it is true that to double the amount of absorption the concentration must be approximately quadrupled, but in weaker solutions absorption is more nearly directly proportional to concentration, while in more concentrated solution the quantity of any given base taken up by a fixed amount of soil is but little affected by. varying the concentration of the solution.

Wolff ${ }^{a}$ in the same year called attention to the fact that the final, not the initial, concentration of the solute is to be considered in discussing. the relation between strength of solution and amount of absorption. According to him, two equal quantities of soil treated with different solutions of a salt will have absorbed identical quantities of base, if after absorption the percentage compositions of the solutions are alike.

This phase of the subject was worked out experimentally for colloids by Van Bemmelen, who showed that the quantity of solute taken up by a given quantity of a colloid was the same, no matter what the original conditions, if only the final concentration of the solution was the same. Among the data illustrating this are the following, 100 millimols metastannic acid $\left(\mathrm{SnO}_{2}\right.$ with about $\left.2 \mathrm{H}_{2} \mathrm{O}\right)$ being used in each case: ${ }^{b}$

Experiments with sulphuric acid and colloid metastannic acid.

\begin{tabular}{|c|c|c|c|c|c|}
\hline \multicolumn{3}{|c|}{ Initial state. } & \multicolumn{3}{|c|}{ Final state. } \\
\hline $\begin{array}{l}\text { Mols } a \\
{ }_{\mathrm{H}_{2} \mathrm{SO}_{4}}\end{array}$ & $\begin{array}{c}\mathrm{Cm}^{3} \\
\mathrm{H}_{2} \mathrm{O} .\end{array}$ & $\begin{array}{c}1 \mathrm{~mol} \\
\mathrm{H}_{2} \mathrm{SO}_{4} \text { in } \\
\mathrm{cm}^{3} .\end{array}$ & $\begin{array}{c}\mathrm{Mols}_{2} \mathrm{SO} \\
\text { taken up } \\
\text { by solid. }\end{array}$ & $\begin{array}{c}\mathrm{Mols}_{\mathrm{H}} \mathrm{SO}_{4} \\
\text { in solu- } \\
\text { tion. }\end{array}$ & $\begin{array}{c}1 \mathrm{~mol} \\
\mathrm{H}_{2} \mathrm{SO}_{4} \text { in } \\
\mathrm{cm}^{3} \text {. }\end{array}$ \\
\hline $\begin{array}{l}20 \\
50 \\
10 \\
20 \\
10 \\
50 \\
10 \\
20\end{array}$ & $\begin{array}{r}10 \\
50 \\
10 \\
80 \\
20 \\
400 \\
40 \\
200\end{array}$ & $\begin{array}{r}1^{\frac{1}{2}} \\
1 \\
4 \\
2 \\
8 \\
4 \\
10\end{array}$ & $\begin{array}{c}11.45 \\
11.2 \\
8.55 \\
8.52 \\
8.07 \\
8.21 \\
7.4 \\
7.5\end{array}$ & $\begin{array}{c}8.55 \\
38.8 \\
1.45 \\
11.48 \\
1.93 \\
41.79 \\
2.6 \\
12.5\end{array}$ & $\begin{array}{c}1.17 \\
1.29 \\
7.0 \\
7.1 \\
10.4 \\
9.56 \\
15.4 \\
16.0\end{array}$ \\
\hline
\end{tabular}

a As used by Van Bemmelen, the mol is the molecular weight taken in milligrams.

Therefore the quantity of salt absorbed by the colloid will be determined by the final concentration of the solution. Water percolating through colloid material will give up its solute to the colloid until equilibrium is reached. After that it will pass through unchanged. A more dilute solution will extract the salt from the colloid until an equilibrium which corresponds to the greater dilution is established. 
The absorption is accordingly, in general, an exponential function of the concentration of the solution. This is the form found by Ostwald ${ }^{a}$ for the solubility of the alkaline earth sulphates in acids of various concentrations and by Meyerhoffer ${ }^{b}$ for the action of potassium carbonate on barium sulphate. This form of the curve is therefore not necessarily an indication that we are dealing with solid solution or adsorption. ${ }^{c}$ The chief reaction where silicates and salt solutions are concerned appears' from the stoichiometrical relations to be undoubtedly double decomposition. Where the reaction consists chiefly in the precipitation of metal hydroxide, as with orthoclase or kaolin and cupric sulphate, the silicate, owing to the weakness of its acid and the consequent tendency of the anion to unite with the hydrogen of water to form the nondissociated acid, acts in a sense as a generator of hydroxyl ions, and here the exponential form of the concentration curve is to be expected. It is to be borne in mind that the conditions examined experimentally are not those of equilibrium, inasmuch as precipitation may be increased by further grinding of the silicate powders. The greater penetrative power of the concentrated solutions, due to their higher osmotic pressure, will undoubtedly determine in some degree the extent of the reaction and therefore the form of the concentration curve.

Van Bemmelen regards the holding of electrolytes by colloids as due to loose chemical combination, and designates the resulting products as "absorption compounds." In many of the cases examined by him ordinary chemical union undoubtedly is responsible for a part, at least, of the phenomena observed, as where stannic oxide is treated with acid or alkali. In some other cases there seems reason to classify the facts as distribution of solute between two solvents-one water, the other a colloid.

No undoubted case of solid solution is known among amorphous substances. $^{d}$

As to the possibility of adsorption, Freundlich ${ }^{e}$ finds that even by charcoal "inorganic salts in water solution are very weakly adsorbed." Indubitable evidence that adsorption of inorganic salts by mineral matter takes place to a measurable extent seems to be lacking.

a Jour. prakt. Chem., vol. 137, 1884, p. 55.

b.Zeitschr. phys. Chem., vol: 53,1905 , p. 530 .

c For a discussion of adsorption, solid solution, and chemical combination see Ostwald, Lehrbuch vol. 2, pt. 3, 1906, pp. 252 and ff.

d Ostwald, Lehrbuch, vol. 2, pt. 3, 1906, p. 253.

$e$ Freundlich, Herbert, Adsorption in solutions: Zeitschr. phys. Chem., vol. 57, December, 1906, pp. 385-470. 


\section{EXPERIMENTAL WORK.}

\section{METHOD OF PROCEDURE.}

In the work carried out in the Geological Survey laboratory ${ }^{a}$ the experimental procedure, except where otherwise specified, was as follows: The mineral, finely ground in an agate mortar, was left several days at room temperature, with occasional shaking, in a wellstoppered flask with twice its weight of the solution. Whether contact was for a few hours or a few months made little difference. The liquid was filtered through a double layer of filter paper in a Gooch crucible, which, except in the case of pure-water extracts, retained the finest powders and gave perfectly clear filtrates. A measured quantity of the filtrate was subjected to analysis. After addition of acid, silica was removed by evaporation, iron and aluminum were precipitated with ammonia, and calcium was separated with ammonium oxalate. Ammonium salts were then driven off by heating, and magnesium was precipitated and washed with barium hydroxide solution and weighed as the sulphate. The barium hydroxide contained a trace (less than 0.1 per cent) of impurity, chiefly potassium and sodium, for which a correction was applied in the one or two cases in which it was of significance. In the filtrate from magnesium hydroxide barium was precipitated with ammonium carbonate, reprecipitated, and the alkalies in the filtrate were weighed as chlorides and separated in the usual way. Repeated tests of the alkali chlorides for magnesium gave, as a rule, an unweighable trace at most-rarely a few tenths of a milligram.

Some idea of the degree of uniformity which can be obtained on repeating these experiments as nearly as possible under the same conditions may be had from the duplicate results with copper sulphate and kaolin. The errors may, however, in less favorable cases, amount to several hundredths of a millimol.

The results are only roughly comparable among different minerals, owing to the impossibility of getting the powders of uniform fineness.

The orthoclase was, except where otherwise specified, from a lot of very fresh cleavage fragments obtained from Delaware County, Pa., through Foote \& Co. Orthoclase A and orthoclase B were from San Diego County, Cal.

$a_{\mathrm{A}}$ preliminary paper giving some of the results of this _work was published in Jour. Am. Chem. Soc., vol. 27, 1905, pp 976-979, and in Economic Geology, vol, 1, 1905, pp. 67-73. 


\section{EXPERIMENTAL RESULTS.}

\section{KAOLIN AND CUPRIC SULPHATE.}

Kaolin: with twice its weight of cupric sulphate solution. The kaolin used was an impalpable powder, most of its particles having a diameter of about 0.002 to $0.003 \mathrm{~mm}$. Examination under the microscope, kindly made by Mr. Lindgren, showed the presence of some undecomposed feldspar. The kaolin was free from carbonate and gave no trace of hydrogen sulphide on heating with acid. The results are stated both in grams and in milligram molecules.

Experiments. with kaolin and cupric sulphate solutions.

COPPER FOUND IN 50 CUBIC CENTIMETERS.

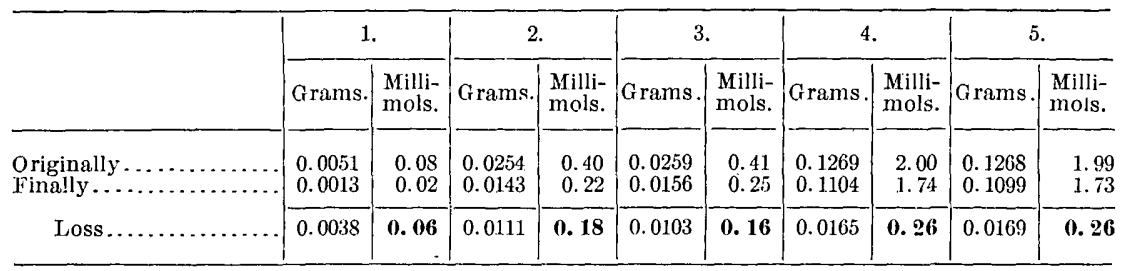

BASES FOUND IN VARIOUS VOLUMES OF FILTRATES.

\begin{tabular}{|c|c|c|c|c|c|c|c|c|c|c|}
\hline \multirow[b]{2}{*}{ Constituent. } & \multicolumn{2}{|c|}{$110 \mathrm{~cm}^{3}$. } & \multicolumn{2}{|c|}{$50 \mathrm{~cm}^{3}$. } & \multicolumn{2}{|c|}{$55 \mathrm{~cm}^{3}$. } & \multicolumn{2}{|c|}{$60 \mathrm{~cm}^{3}$. } & \multicolumn{2}{|c|}{$60 \mathrm{~cm}^{3}$. } \\
\hline & Grams. & $\begin{array}{l}\text { Milli- } \\
\text { mols. }\end{array}$ & Grams. & $\begin{array}{l}\text { Milli- } \\
\text { mols. }\end{array}$ & Grams. & $\begin{array}{l}\text { Milli- } \\
\text { mols. }\end{array}$ & Grams. & $\begin{array}{l}\text { Milli- } \\
\text { mols. }\end{array}$ & Grams. & $\begin{array}{l}\text { Milli- } \\
\text { mols. }\end{array}$ \\
\hline $\begin{array}{l}\mathrm{SiO}_{2} \ldots \ldots \\
\mathrm{Fe}_{2} \mathrm{O}_{3}, \mathrm{Al}_{2} \mathrm{O}_{3} \\
\mathrm{CaO} \ldots \ldots \ldots \\
\mathrm{MgO}^{\mathrm{MgO}} \ldots \ldots \ldots \\
\mathrm{K}_{2} \mathrm{O} \ldots \ldots \ldots \\
\mathrm{Na}_{2} \mathrm{O} \ldots \ldots \ldots\end{array}$ & $\begin{array}{l}0.0026 \\
0.0008 \\
0.0042 \\
0.0032 \\
0.0016 \\
0.0020\end{array}$ & $\begin{array}{r}a 0.02 \\
0.08 \\
0.08 \\
0.02 \\
0.03\end{array}$ & $\begin{array}{l}0.0026 \\
0,0020 \\
0.0048 \\
0.0031 \\
0.0010 \\
0.0015\end{array}$ & $\begin{array}{l}0.06 \\
0.09 \\
0.08 \\
0.01 \\
0.02\end{array}$ & $\begin{array}{l}0.0006 \\
0.0004 \\
0.0051 \\
0.0037 \\
0.0011 \\
0.0027\end{array}$ & $\begin{array}{l}0.01 \\
0.09 \\
0.09 \\
0.01 \\
0.04\end{array}$ & $\begin{array}{l}0.0020 \\
0.0018 \\
0.0066 \\
0.0042 \\
0.0018 \\
0.0016\end{array}$ & $\begin{array}{l}0.05 \\
0.12 \\
0.11 \\
0.02 \\
0.03\end{array}$ & $\begin{array}{l}0.0013 \\
0.0025 \\
0.0066 \\
0.0040 \\
0.0013 \\
0.0020\end{array}$ & $\begin{array}{l}0.07 \\
0.12 \\
0.10 \\
0.01 \\
0.03\end{array}$ \\
\hline $\begin{array}{l}\text { Total ... } \\
\text { Total gain in } 50 \mathrm{~cm}^{3} \text {. }\end{array}$ & $\begin{array}{l}0.0144 \\
0.0065\end{array}$ & $\begin{array}{r}0.23 \\
0.10\end{array}$ & $\begin{array}{l}0.0150 \\
0.0150\end{array}$ & $\begin{array}{r}0.26 \\
\text { 0. } 26\end{array}$ & $\begin{array}{l}0.0136 \\
0.0126\end{array}$ & $\begin{array}{r}0.24 \\
0.22\end{array}$ & $\begin{array}{l}0.0180 \\
0.0150\end{array}$ & $\begin{array}{r}0.33 \\
0.28\end{array}$ & $\begin{array}{l}0.0177 \\
0.0148\end{array}$ & $\begin{array}{r}0.33 \\
0.28\end{array}$ \\
\hline
\end{tabular}

$a$ In this table and in those following the figures given for millimols ferric and aluminum oxides express the number of divalent millimols to which the quantities of these bases found are equivalent, the millimol being the molecular weight taken in milligrams.

Fifty grams washed kaolin taken with $100 \mathrm{~cm}^{3}$ distilled water. Solution neutral to litmus. Found in $50 \mathrm{~cm}^{3}$ (as sulphates): ${ }^{a}$

Experimient with kaolin and water.

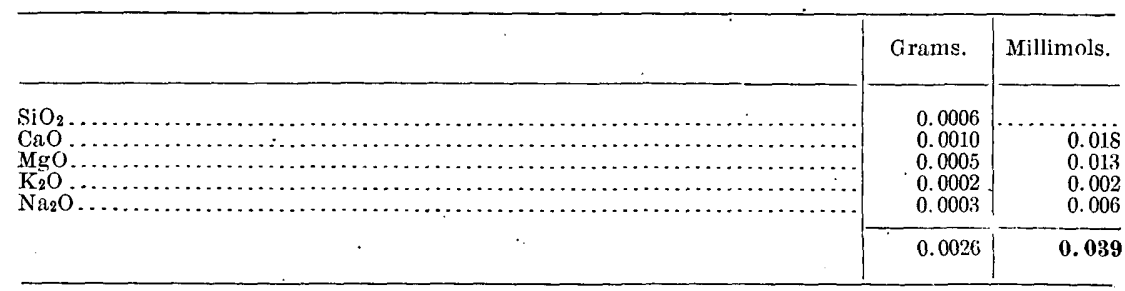

a Corrections have been applied to these figures for impurities in the barium hydroxide solution used as follows: $\mathrm{MgO} 0.0001, \mathrm{~K}_{2} \mathrm{O} 0.0004, \mathrm{Na}_{2} \mathrm{O} 0.0006$ gram. 
Subtracting from the bases dissolved by copper sulphate solution that quantity which water alone takes up from the kaolin, 0.04 millimol, we have the following comparison of the copper precipitated and the bases replacing it:

Comparison of copper: precipitated with bases dissolved.

\begin{tabular}{|c|c|c|c|c|c|}
\hline \multirow[b]{2}{*}{ Original concentration. . } & \multicolumn{5}{|c|}{ Millimols in $50 \mathrm{~cm}^{3}$. } \\
\hline & 0.08 & 0.40 & 0.41 & 2.00 & 1.99 \\
\hline $\begin{array}{l}\text { Copper precipitated ... } \\
\text { Bases dissolved, corr.. }\end{array}$ & $\begin{array}{l}0.06 \\
0.06\end{array}$ & $\begin{array}{ll}0.18 \\
0.22\end{array}$ & $\begin{array}{l}0.16 \\
0.18\end{array}$ & $\begin{array}{l}0.26 \\
0.24\end{array}$ & $\begin{array}{l}0.26 \\
0.24\end{array}$ \\
\hline
\end{tabular}

The agreement is sufficient to show that the main reaction which takes place is an exchange of bases in equivalent quantities between the kaolin and the solution. Any adsorption that occurs is probably not over 0.02 millimol or 0.0013 gram copper, which in 25 grams kaolin is one in 20,000. In the case in which the bases are 0.04 millimol in excess the solution had unusual opportunity to dissolve material from glass, in which it stood for about five months.

Copper sulphate solution containing 2 millimols in $50 \mathrm{~cm}^{3}$ when filtered through 25 grams of kaolin in a column $1 \mathrm{~cm}$. in diameter came through at first colorless and contained chiefly calcium sulphate.

The investigation of the action of kaolin was suggested by Kohler's paper on adsorption, to which reference has already been made. ${ }^{a}$ The instances cited by Kohler of association of ore with kaolin while neighboring sandstone free from kaolin contains no metal seem attributable to chemical precipitation by residual silicate or aluminosilicate in the kaolin rather than to adsorption.

\section{INFLUENCE OF SURFACE.}

The surface exposed by a finely powdered mineral to the action of the salt solutions is of course very large, and it is only by multiplication of the reaction velocity in some such way that these changes become at all accessible to laboratory investigation. It may be remarked that fine grinding appears to be a less exceptionable means to this end than the use of high temperatures, which may give a very different result from that which would be obtained in a longer time at lower temperatures. The final equilibrium is not affected by fineness of division of the reacting solid. It is in general affected by a variation in temperature.

The surface actually exposed to a salt solution even in the case of a fresh rock in place is perhaps greater than is apparent. The permeability of such rocks was illustrated in the course of work with 
selected cleavage fragments of very fresh orthoclase, which had lain for some months in a copper sulphate solution. In order to examine the surface of the feldspar the solution was poured off and the mineral very carefully and thoroughly washed with water and set aside to dry. Some days later minute crystals of copper sulphate were found on the surface of the mineral at points where no crack was visible to the eye. These were dissolved by soaking the fragments in water, and the surface was again thoroughly washed, with the same result at the end of a few days. Copper sulphate solution which had penetrated numberless interstices in the apparently unaltered mineral again came to the surface and deposited crystals. The washing was repeated many times with the same result.

That the extent to which silicate and solution exchange bases is dependent upon the surface exposed is evident from the following experiments, in which the amount of copper precipitated increases as the grinding is carried further.

Washed kaolin with cupric sulphate solution containing originally 0.1263 gram copper in $50 \mathrm{~cm}^{3}$ precipitates 0.0165 gram copper. Agitating the mixture continuously for about two weeks increases the amount of copper precipitated to $0.0183 \mathrm{gram}$, and kaolin previously ground in the agate mortar precipitates under similar conditions as much as 0.0584 gram.

Orthoclase from San Diego County, Cal., ground for four hours, precipitated 0.0268 gram copper, while another portion of the same feldspar ground for about fifteen hours removed 0.0798 gram copper, other conditions being the same.

Onthoclase from Delaware County, $\mathrm{Pa}$., precipitated 0.0469 gram copper; ground a few hours longer, 0.0656 gram; two portions of another sample, still more finely powdered, precipitated respectively 0.0728 gram after two days' contact and 0.0730 gram after twelve days.

\section{ORTHOCLASE AND SALT SOLUTIONS.}

The orthoclase used was in two lots of different fineness. Twentyfive grams of one lot precipitated from $50 \mathrm{~cm}^{3} 1$ per cent cupric sulphate solution 0.0730 gram copper; of the other, 0.0469 gram. These numbers are in the ratio $1.554: 1$. The quantities of the various metals precipitated and bases dissolved are assembled in the following table. Twenty-five grams orthoclase and $50 \mathrm{~cm}^{3}$ solution were used in each case. The results obtained with the coarser feldspar, indicated by $*$, have been multiplied by 1.554 and are what might be expected if feldspar of uniform fineness were used. 
Summary of results with orthoclase and salt solutions.

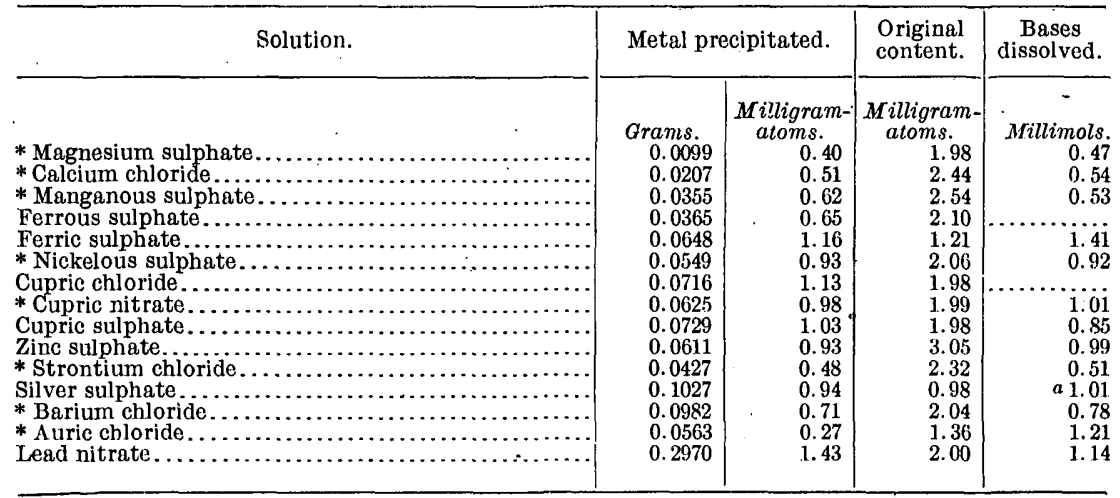

a Milli-equivalents.

Owing to the fact that orthoclase gives up a perceptible quantity of alkali to water, the bases dissolved will be a few hundredths of a millimol in excess of the metal precipitated in those cases in which no basic salt is formed. Where the precipitate contains basic salt, the bases going into solution throw out more than their equivalent of metal. The auric chloride solution has, owing to acidity resulting from hydrolysis; dissolved bases in excess of the metal precipitated.

\section{ORTHOCLASE AND CUPRIC SULPHATE.}

Experiments.-Orthoclase A (from San Diego County, Cal.), containing 11.98 per cent $\mathrm{K}_{2} \mathrm{O}, 3.32$ per cent $\mathrm{Na}_{2} \mathrm{O}$; free from carbonates. In the first experiment the sample had been ground for four hours, in the second for fifteen hours. Contact was for one hour and overnight, respectively.

Experiments with orthoclase and cupric sulphate.

\begin{tabular}{|c|c|c|c|c|}
\hline \multirow[b]{2}{*}{ Constituent. } & \multicolumn{2}{|c|}{1.} & \multicolumn{2}{|c|}{2.} \\
\hline & Grams. & $\begin{array}{l}\text { Milli- } \\
\text { mols. }\end{array}$ & Grams. & $\begin{array}{l}\text { Milli- } \\
\text { mols. }\end{array}$ \\
\hline $\begin{array}{l}\text { Copper in } 50 \mathrm{~cm}^{3}: \\
\text { Originally } \\
\text { Finnlly } . . . . . .\end{array}$ & $\begin{array}{l}0.1262 \\
0.0994\end{array}$ & $\begin{array}{l}1.98 \\
1.56\end{array}$ & $\begin{array}{l}0.1266 \\
0.0468\end{array}$ & $\begin{array}{l}1.99 \\
0.74\end{array}$ \\
\hline Ioss... & 0.0268 & 0.42 & 0.0798 & 1.25 \\
\hline 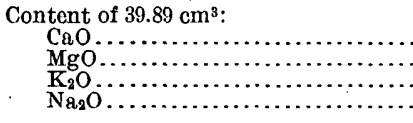 & & $\begin{array}{l}\ldots \ldots \ldots \\
\ldots \ldots \ldots \\
\cdots \ldots \ldots\end{array}$ & $\begin{array}{l}0.0015 \\
0.0018 \\
0.0348 \\
0.0212\end{array}$ & $\begin{array}{l}0.03 \\
0.05 \\
0.37 \\
0.34\end{array}$ \\
\hline Total... & 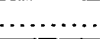 & $\ldots \ldots \ldots$ & 0.0593 & 0.79 \\
\hline Content of $50 \mathrm{~cm}^{3}$. & & 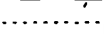 & 0.0743 & 1.18 \\
\hline
\end{tabular}


Orthoclase B (San Diego County, Cal.), containing 8.26 per cent $\mathrm{K}_{2} \mathrm{O}, 4.38$ per cent $\mathrm{Na}_{2} \mathrm{O}$, 0.03 per cent $\mathrm{CO}_{2}(=0.0075$ gram or 0.17 millimol $\mathrm{CO}_{2}$ in 25 grams feldspar). In contact overnight with cupric sulphate solution.

Experiment with orthoclase and cupric sulphate.

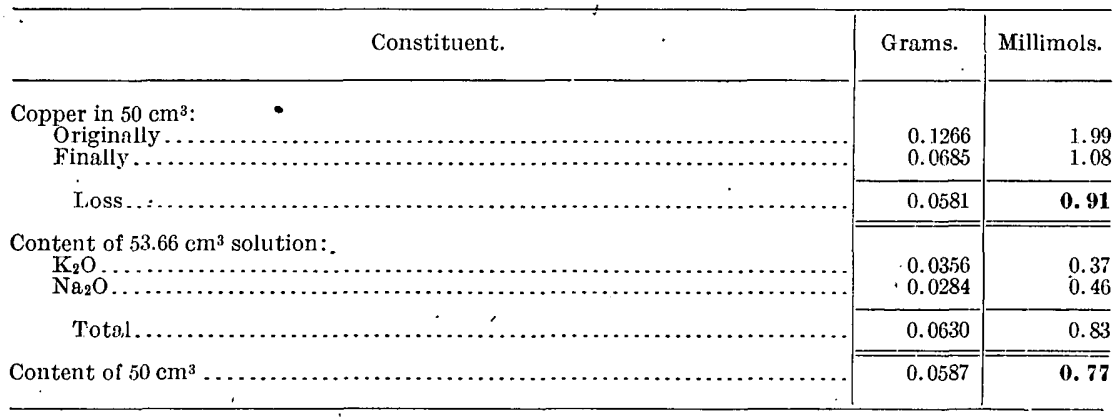

Influence of concentration.-The influence of concentration of the cupric sulphate solution is foreshadowed by earlier work with other substances. The more concentrated the solution the greater the quantity of copper precipitated under similar conditions. Precipitation is not, however, proportional to concentration, but increases more slowly than the latter. In concentrated solutions a change in the concentration has comparatively little effect on the amount precipitated. A few determinations of the quantity of sulphate radical precipitated with the copper are appended. No definite relation appears between the two. In very, dilute solution, where the copper is almost completely precipitated, the proportion of acid radical carried down decreases.

Experiments with orthoclase and cupric sulphate, showing influence of concentration.

\begin{tabular}{|c|c|c|c|c|c|c|c|c|c|c|}
\hline \multirow[b]{2}{*}{ Constituent. } & \multicolumn{10}{|c|}{ Content in $50 \mathrm{~cm}^{3}$. } \\
\hline & Grams. & $\begin{array}{l}\text { Milli- } \\
\text { mols. }\end{array}$ & Grams. & $\begin{array}{l}\text { Milli- } \\
\text { mols. }\end{array}$ & Grams. & $\begin{array}{l}\text { Milli- } \\
\text { mols. }\end{array}$ & Grams & $\begin{array}{l}\text { Milli- } \\
\text { rnols. }\end{array}$ & Grams. & $\begin{array}{l}\text { Milli- } \\
\text { mols. }\end{array}$ \\
\hline $\begin{array}{l}\text { Copper: } \\
\text { Originally } \\
\quad \text { Finally } . . .\end{array}$ & $\begin{array}{c}0.0316 \\
\text { Trace. }\end{array}$ & $\begin{array}{r}0.497 \\
0\end{array}$ & $\begin{array}{l}0.0632 \\
0.0215\end{array}$ & $\begin{array}{l}0.994 \\
0.338\end{array}$ & $\begin{array}{r}a 0.1263 \\
0.0794\end{array}$ & $\begin{array}{l}1.99 \\
1.24\end{array}$ & $\begin{array}{l}1.487 \\
1.403\end{array}$ & $\begin{array}{r}23.39 \\
22.06\end{array}$ & $\begin{array}{l}2.978 \\
2.873\end{array}$ & $\begin{array}{l}46.82 \\
45.17\end{array}$ \\
\hline $\begin{array}{c}\text { Loss........ } \\
\text { Sulphate radical: } \\
\text { Originally.... } \\
\text { Finally....... }\end{array}$ & $\begin{array}{l}0.0316 \\
0.0481 \\
0.0453\end{array}$ & $\begin{array}{l}0.497 \\
0.501 \\
0.472\end{array}$ & $\begin{array}{l}0.0417 \\
0.0961 \\
0.0870\end{array}$ & $\begin{array}{l}0.656 \\
1.001 \\
0.906\end{array}$ & 0.0469 & 0.75 & $b 0.084$ & c 1.33 & $d 0.105$ & e 1.65 \\
\hline Loss.. & 0.0028 & 0.029 & 0.0091 & 0.095 & & & & & & \\
\hline
\end{tabular}

a A solution of this original concentration treated with the same orthoclase, more finely ground, lost $1.03 \mathrm{mols}$ copper and $0.176 \mathrm{~mol} \mathrm{SO}_{4}$; and with the orthoclase still more finely pulverized $1.15 \mathrm{mols}$ copper and $0.182 \mathrm{~mol} \mathrm{SO}_{4}$.

$\begin{array}{lll}b \pm 0.002 . & c \pm 0.02 . & d \pm 0.003 .\end{array}$

Influence of temperature.-The change in amount of precipitation caused by raising the temperature was found to be slight. Ortho- 
clase with cupric sulphate heated for a few minutes on the water bath precipitated 0.082 gram copper as compared with 0.073 gram cold.

\section{ORTHOCLASE WITH CUPRIC SULPHATE AND SULPHURIC ACD.}

Twenty-five grams powdered orthoclase with $50 \mathrm{~cm}^{3}$ cupric sulphate solution and $0.7 \mathrm{~cm}^{3} 5.8$ normal sulphuric acid ( $=2.03$ millimols). Filtered after two days.

Experiment with orthoclase and cupric sulphate and sulphuric acid.

\begin{tabular}{|c|c|c|}
\hline Constituent. & Grams. & Millimols. \\
\hline $\begin{array}{l}\text { Copper in } 50.7 \mathrm{~cm}^{3}: \\
\quad \text { Originally } \ldots \ldots \ldots \ldots \ldots \ldots \ldots \ldots \ldots \ldots \ldots \ldots \ldots \ldots\end{array}$ & $\begin{array}{l}0.1263 \\
0.1214\end{array}$ & $\begin{array}{l}1.99 \\
1.91\end{array}$ \\
\hline Loss.. & 0.0049 & 0.08 \\
\hline 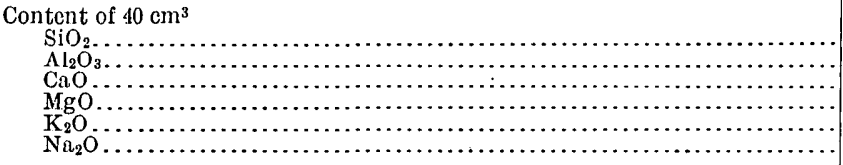 & $\begin{array}{l}0.0122 \\
0.0248 \\
0.0016 \\
0.0019 \\
0.0635 \\
0.0125\end{array}$ & $\begin{array}{r}a 0.73 \\
0.03 \\
0.05 \\
0.68 \\
0.20\end{array}$ \\
\hline Total........ & 0.1165 & 1.69 \\
\hline $\begin{array}{l}\text { Content of } 50.7 \mathrm{~cm}^{3} \ldots \ldots \ldots \ldots \ldots . . \\
+\end{array}$ & 0.1477 & 2.14 \\
\hline
\end{tabular}

$a$ The alumina found is equivalent to 0.73 divalent millimol.

The bases dissolved are equivalent to the sulphuric acid present plus the copper precipitated. The orthoclase has therefore neutralized the dilute sulphuric acid solution (0.2 gram sulphuric acid in 50 $\mathrm{cm}^{3}$ ). The copper precipitated is but a small fraction of that precipitated from unacidified solution.

\section{ORTHOCLASE AND CUPRIC NITRATE.}

Filtered after two days.

Experiment with orthoclase and cupric nitrate.

\begin{tabular}{|c|c|c|}
\hline Constituent. & Grams. & Millimols. \\
\hline $\begin{array}{l}\text { Copper in } 50 \mathrm{~cm}^{3}: \\
\text { Originally } \ldots \ldots \ldots \ldots \ldots \ldots \ldots \\
\text { Finally } \ldots \ldots \ldots \ldots \ldots \ldots \ldots \ldots\end{array}$ & $\begin{array}{l}0.1267 \\
0.0865\end{array}$ & $\begin{array}{l}1.99 \\
1.36\end{array}$ \\
\hline Loss... & 0.0402 & 0.63 \\
\hline 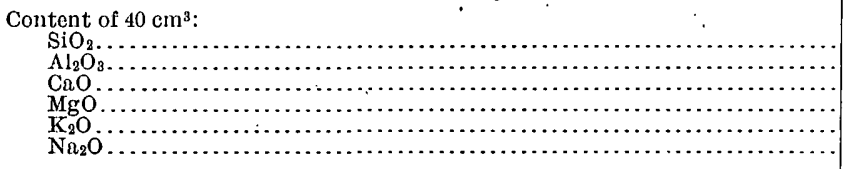 & $\begin{array}{l}0.0027 \\
0.0006 \\
0.0006 \\
0.0008 \\
0.0323 \\
0.0080\end{array}$ & $\begin{array}{l}0.02 \\
0.01 \\
0.02 \\
0.34 \\
0.13\end{array}$ \\
\hline Total........ & 0.0450 & 0.52 \\
\hline Content of $50 \mathrm{~cm}^{3} \ldots$. & 0.0563 & 0.65 \\
\hline
\end{tabular}


ORTHOCLASE AND CUPRIC CHLORIDE.

Filtered after three days.

Experiment with orthoclase and cupric chloride.

\begin{tabular}{|c|c|c|}
\hline Constituent. & Grams. & Millimols. \\
\hline $\begin{array}{l}\text { Copper in } 50 \mathrm{~cm}^{3}: \\
\quad \text { Originally } \ldots \ldots \ldots \ldots \\
\quad \text { Finally } \ldots \ldots \ldots\end{array}$ & $\begin{array}{r}0.1258 \\
\\
0.0542\end{array}$ & $\begin{array}{l}1.98 \\
0.85\end{array}$ \\
\hline I.oss... & 0.0716 & 1.13 \\
\hline
\end{tabular}

For comparison of the precipitation from sulphate, chloride, and nitrate of copper, see page 41 .

\section{ORTHOCLASE AND SILVER SULPHATE.}

Twenty-five grams powdered orthoclase in contact for two days with $50 \mathrm{~cm}^{3}$ silver sulphate solution: The silver was almost completely precipitated.

Experiment with orthoclase and silver sulphate.

\begin{tabular}{|c|c|c|}
\hline Constituent. & Grams. & $\begin{array}{l}\text { Milli- } \\
\text { equiva- } \\
\text { lents. }\end{array}$ \\
\hline 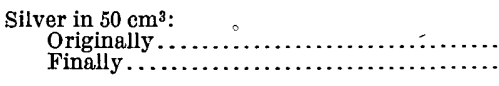 & $\begin{array}{l}0.1066 \\
0.0039 \\
\end{array}$ & $\begin{array}{l}0.98 \\
0.04\end{array}$ \\
\hline Loss.................. & 0.1027 & 0.94 \\
\hline 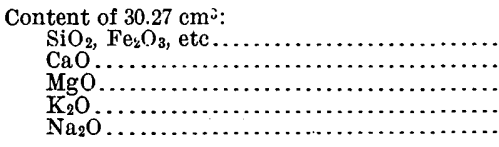 & $\begin{array}{l}0.0007 \\
0.0001 \\
0.0004 \\
0.0170 \\
0.0073\end{array}$ & $\begin{array}{l}\ldots . .3 \\
0.02 \\
0.36 \\
0.23\end{array}$ \\
\hline Total.... & 0.0255 & $\overline{0.61}$ \\
\hline Total in $50 \mathrm{~cm}^{3} . \ldots$. . & 0.0421 & 1.01 \\
\hline
\end{tabular}

\section{ORTHOCLASE AND LEAD NITRATE.}

Twenty-five grams powdered orthoclase with $50 \mathrm{~cm}^{3}$ lead nitrate solution. Filtered after five days.

Experiment with orthoclase and lead nitrate.

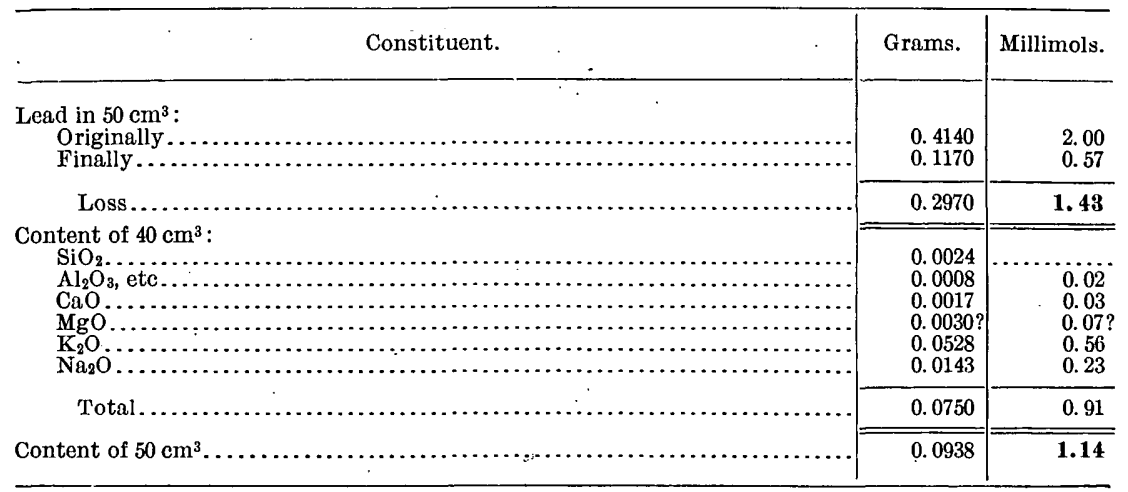




\section{ORTHOCLASE AND GOLD CHLORIDE.}

Twenty-five grams powdered orthoclase with $50 \mathrm{~cm}^{3}$ auric chloride solution $\left(\mathrm{AuCl}_{3}\right)$, which contained a slight excess of hydrochloric acid (0.03 millimol, determined by precipitation as silver chloride). The bases dissolved are in no apparent relation to the gold precipitated, being in very decided excess.

Experiment with orthoclase and gold chloride.

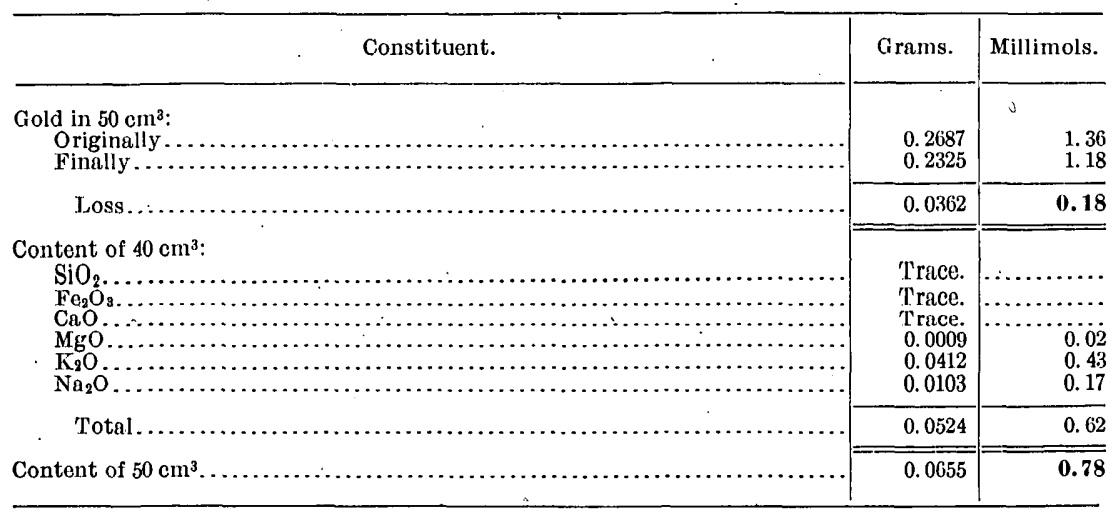

Gold was not precipitated from hydroaurichloric acid $\left(\mathrm{HAuCl}_{4}\right)$ solution by orthoclase.

\section{ORTHOCLASE AND ZINC SULPHATE.}

Twenty-five grams powdered orthoclase with $50 \mathrm{~cm}^{3}$ zinc sulphate solution. Filtered after two days.

Experiment with orthoclase and zinc sulphate.

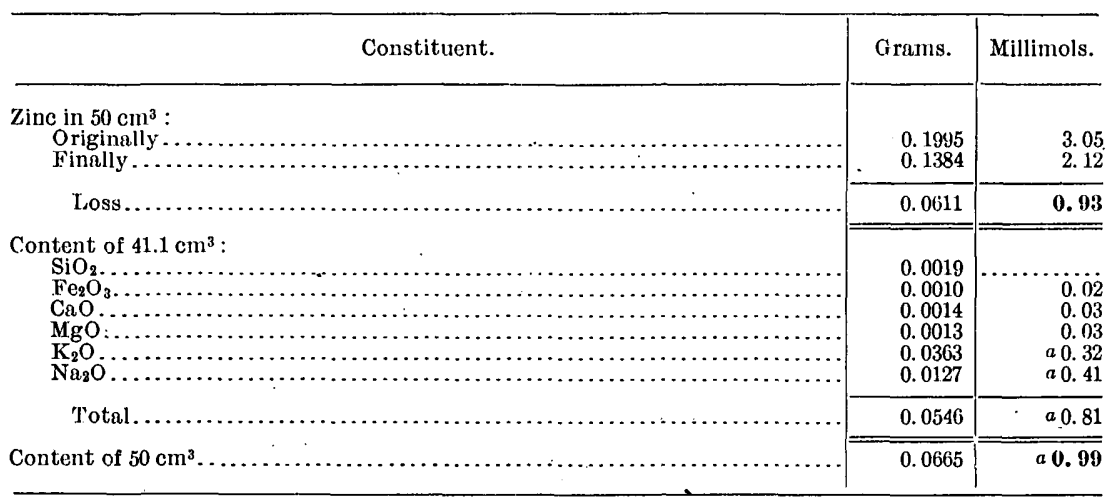

a The result for $\mathrm{K}_{2} \mathrm{O}$ is low, that for $\mathrm{Na}_{2} \mathrm{O}$ is high, and the totals are high.

\section{KAOLIN AND ZINC SULPHATE.}

Twenty-five grams kaiolin in contact two days with $50 \mathrm{~cm}^{3}$ of the same zinc sulphate solution precipitated 0.0169 gram (0.26 millimol) zinc. 


\section{ORTHOCLASE AND FERROUS SULPHATE.}

Twenty-five grams orthoclase with $50 \mathrm{~cm}^{3}$ ferrous sulphate solution in stoppered flask of some $200 \mathrm{~cm}^{3}$ capacity. The air was not removed from the flask before stoppering. After two days the orthoclase, originally pure white, had taken on a light chocolate color, due to precipitated iron. Fifty $\mathrm{cm}^{3}$ ferrous sulphate solution, similarly inclosed in a flask without orthoclase, showed no perceptible precipitate at the end of two days. The orthoclase, by rendering the solution alkaline, had accelerated oxidation and thus precipitation.

Experiment with orthoclase and ferrous sulphate: Iron in $50 \mathrm{~cm}^{3}$.

\begin{tabular}{|c|c|c|}
\hline & Grams. & Millimols. \\
\hline $\begin{array}{l}\text { Originally } \ldots \ldots \ldots \ldots \ldots \ldots \ldots \ldots \ldots \ldots \ldots \ldots \ldots \ldots \\
\text { Finally } \ldots \ldots \ldots \ldots \ldots \ldots \ldots\end{array}$ & $\begin{array}{l}0.1178 \\
0.0813\end{array}$ & $\begin{array}{l}2.10 \\
1.45\end{array}$ \\
\hline Loss.... & 0.0365 & 0.65 \\
\hline
\end{tabular}

In a similar experiment in which some pains were taken to exclude air only 0.016 gram iron was precipitated.

\section{KAOLIN AND FERROUS SULPHATE.}

Twenty-five grams kaolin in presence of air with $50 \mathrm{~cm}^{3}$ ferrous sulphate solution of about the same concentration as in the experiment with orthoclase removed approximately 0.015 gram $(0.27$ millimol) iron.

\section{ORTHOCLASE AND FERRIC SULPHATE.}

Twenty-five grams powdered orthoclase with $50 \mathrm{~cm}^{3}$ ferric sulphate solution. Filtered after three weeks. But a trace of iron remained in the filtrate.

Experiment with orthoclase and ferric sulphate.

\begin{tabular}{|c|c|c|c|}
\hline & Constituent. & Grams. & Millimols. \\
\hline $\begin{array}{l}\text { Iron in } 50 \mathrm{~cm}^{3}: \\
\quad \text { Originally } \ldots . . . \\
\quad \text { Finally } \ldots \ldots . . .\end{array}$ & 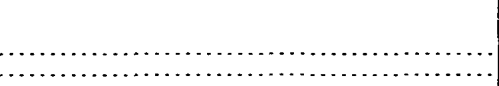 & $\begin{array}{l}. \\
0.0675 \\
0.0027\end{array}$ & $\begin{array}{l}1.21 \\
0.05\end{array}$ \\
\hline Loss.... & & 0.0648 & a 1.16 \\
\hline 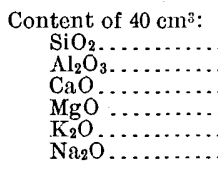 & 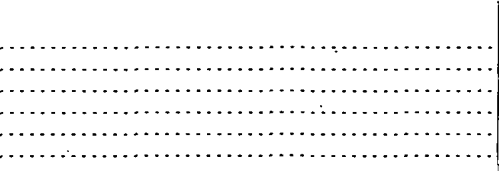 & $\begin{array}{l}0.0067 \\
0.0114 \\
0.0023 \\
0.0012 \\
0.0519 \\
0.0103\end{array}$ & $\begin{array}{l}0.34 \\
0.04 \\
0.03 \\
0.55 \\
0.17\end{array}$ \\
\hline Total... & & 0.0838 & 1.13 \\
\hline Content of $50 \mathrm{~cm}^{3}$ & & 0.1058 & $b 1.41$ \\
\hline
\end{tabular}


Barium sulphate obtained from $50 \mathrm{~cm}^{3}$ ferric sulphate solution after contact with orthoclase was 0.3528 gram, or 1.514 millimols; before contact (assumed equivalent to iron), 1.810 millimols. The loss of sulphate radical, 0.296 millimol, or 0.592 milli-equivalent, plus the gain in bases, 2.82 milli-equivalents, equals 3.412 milli-equivalents, practically identical with the loss of iron.

\section{ORTHOCLASE AND MANGANOUS SULPHATE.}

Twenty-five grams powdered orthoclase with $50 \mathrm{~cm}^{3}$ manganous sulphate solution. Filtered after two weeks.

Experiment with orthoclase and manganous sulphate.

\begin{tabular}{|c|c|c|}
\hline Constituent. & Grams. & Millimols. \\
\hline $\begin{array}{l}\text { Manganese in } 50 \mathrm{~cm}^{3} \text { : } \\
\text { Originally } \ldots \ldots \ldots \ldots \ldots \ldots \ldots \ldots \ldots \ldots \\
\text { Finally } \ldots \ldots \ldots \ldots \ldots \ldots \ldots \ldots \ldots \ldots \ldots\end{array}$ & $\begin{array}{l}0.1397 \\
0.1175\end{array}$ & $\begin{array}{l}2.54 \\
2.14\end{array}$ \\
\hline Loss... & 0.0222 & 0.40 \\
\hline 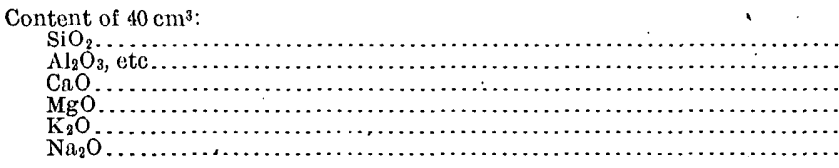 & $\begin{array}{l}0.0026 \\
0.0004 \\
0.0012 \\
0.0013 \\
0.0183 \\
0.0013\end{array}$ & $\begin{array}{l}0.01 \\
0.02 \\
0.03 \\
0.19 \\
0.02\end{array}$ \\
\hline Total..... & 0.0251 & 0.27 \\
\hline Content of $50 \mathrm{~cm}^{3} \ldots \ldots \ldots$ & 0.0314 & 0.34 \\
\hline
\end{tabular}

ORTHOCLASE AND NICKEL SULPHATE.

Twenty-five grams powdered orthoclase with $50 \mathrm{~cm}^{3}$ nickel sulphate solution. Filtered after two weeks' contact.

Experiment with orthoclase and nickel sulphate.

\begin{tabular}{|c|c|c|}
\hline Constituent. & Grams. & Millimols. \\
\hline $\begin{array}{l}\text { Nickel in } 50 \mathrm{~cm}^{3}: \\
\quad \text { Originally } \ldots \ldots \ldots \ldots \ldots \ldots \ldots \ldots \ldots \ldots \\
\text { Finally } \ldots \ldots \ldots \ldots \ldots \ldots \ldots \ldots\end{array}$ & $\begin{array}{l}0.1209 \\
0.0856 \\
\end{array}$ & $\begin{array}{l}2.06 \\
1.46 \\
\end{array}$ \\
\hline Loss.... & 0.0353 & 0.60 \\
\hline 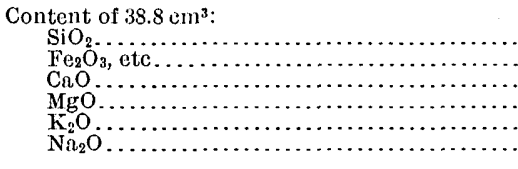 & $\begin{array}{l}0.0031 \\
0.0001 \\
0.0008 \\
0.0032 \\
0.0245 \\
0.0069 \\
\end{array}$ & $\begin{array}{l} \\
\ldots \ldots . \\
0.01 \\
0.08 \\
0.26 \\
0.11 \\
\end{array}$ \\
\hline Total..... & 0.0386 & 0.46 \\
\hline Content of $50 \mathrm{~cm}^{3}$. & 0.0496 & 0.59 \\
\hline
\end{tabular}

ORTHOCLASE AND MAGNESIUM SULPHATE.

Twenty-five grams powdered orthoclase with $50 \mathrm{~cm}^{3}$ magnesium sulphate solution, 
Experiment with orthoclase and magnesium sulphate.

\begin{tabular}{|c|c|c|}
\hline Constituent. & Ġrams. & Millimols. \\
\hline $\begin{array}{l}\text { Magnesium in } 50 \mathrm{~cm}^{3}: \\
\quad \text { Originally } \ldots \ldots \ldots \ldots \ldots \ldots \ldots \ldots \ldots \ldots\end{array}$ & $\begin{array}{c}0.0481 \\
.0 .0417\end{array}$ & $\begin{array}{l}1.98 \\
1.71\end{array}$ \\
\hline Loss.......... & 0.0064 & $>0.26$ \\
\hline 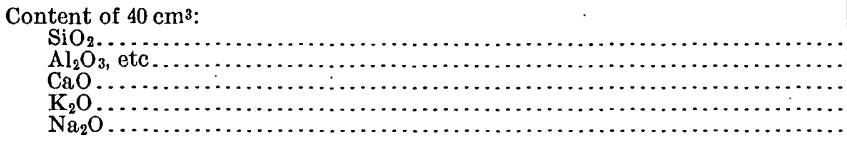 & $\begin{array}{l}0.0012 \\
0.0006 \\
0.0016 \\
0.0118 \\
0.0045\end{array}$ & $\begin{array}{r}0.02 \\
0.03 \\
0.12 \\
0.07\end{array}$ \\
\hline Total. & 0.0197 & 0.24 \\
\hline Content of $50 \mathrm{~cm}^{3} \ldots$ & 0.0246 & $\overline{0.30}$ \\
\hline
\end{tabular}

ORTHOCLASE AND CALCIUM CHLORIDE.

Twenty-five grams powdered orthoclase with $50 \mathrm{~cm}^{3}$ calcium chloride solution. Filtered after five days.

Experiment with orthoclase and calcium chloride.

\begin{tabular}{|c|c|c|}
\hline Constituent. & Grams. & Millimols. \\
\hline $\begin{array}{l}\text { Calcium in } 50 \mathrm{~cm}^{8}: \\
\quad \text { Originally } \ldots \ldots \ldots \ldots \ldots \ldots \ldots \ldots \\
\text { Finally } \ldots \ldots \ldots \ldots \ldots \ldots \ldots\end{array}$ & $\begin{array}{l}0.0977 \\
0.0844\end{array}$ & $\begin{array}{l}2.44 \\
2.11 \\
\end{array}$ \\
\hline Iross..... & 0.0133 & 0.33 \\
\hline 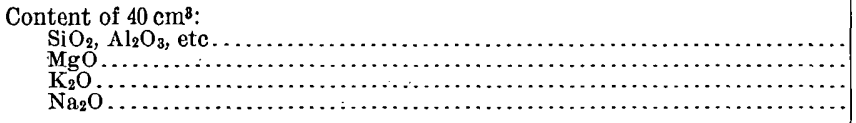 & $\begin{array}{l}0.0012 \\
0.0004 \\
0.0179 \\
0.0048\end{array}$ & $\begin{array}{l}0.01 \\
0.19 \\
0.08\end{array}$ \\
\hline Total... & 0.0243 & 0.28 \\
\hline Content of $50 \mathrm{~cm}^{3}$. & 0.0304 & 0.35 \\
\hline
\end{tabular}

\section{ORTHOCLASE AND STRONTIUM CHLORIDE.}

Twenty-five grams powdered orthoclase with $50 \mathrm{~cm}^{3}$ strontium chloride solution. Filtered after seven days.

Experiment with orthoclase and strontium chloride.

\begin{tabular}{|c|c|c|}
\hline Constituent. & Grams. & Millimols. \\
\hline \multirow[t]{2}{*}{$\begin{array}{r}\text { Strontium in } 50 \mathrm{~cm}^{\mathrm{a}}: \\
\text { Originally } \ldots \ldots \\
\text { Finally } \ldots \ldots \ldots\end{array}$} & $\begin{array}{l}0.2032 \\
0.1757\end{array}$ & $\begin{array}{l}2.32 \\
2.01\end{array}$ \\
\hline & 0.0275 & 0.31 \\
\hline \multirow{2}{*}{ 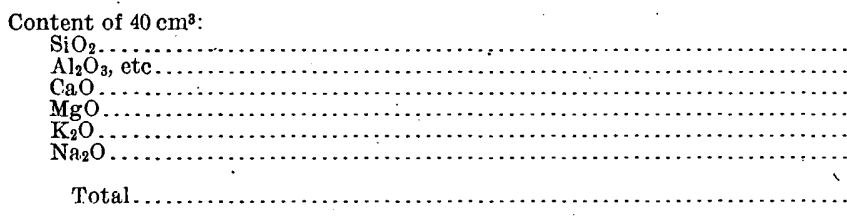 } & $\begin{array}{l}0.0007 \\
0.0004 \\
0.0008 \\
0.0005 \\
0.0157 \\
0.0056\end{array}$ & $\begin{array}{r}0.01 \\
0.01 \\
0.01 \\
0.17 \\
0.09\end{array}$ \\
\hline & 0.0237 & 0.29 \\
\hline \multirow[t]{2}{*}{ 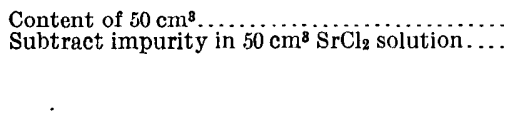 } & $\begin{array}{l}0.0296 \\
0.0017\end{array}$ & $\begin{array}{l}0.36 \\
0.03\end{array}$ \\
\hline & 0.0279 & 0.33 \\
\hline
\end{tabular}


ORTHOCLASE AND BARIUM CHLORIDE.

Twenty-five grams powdered orthoclase with $50 \mathrm{~cm}^{3}$ barium chloride solution. Filtered after four days.

Experiment with orthoclase and barium chloride.

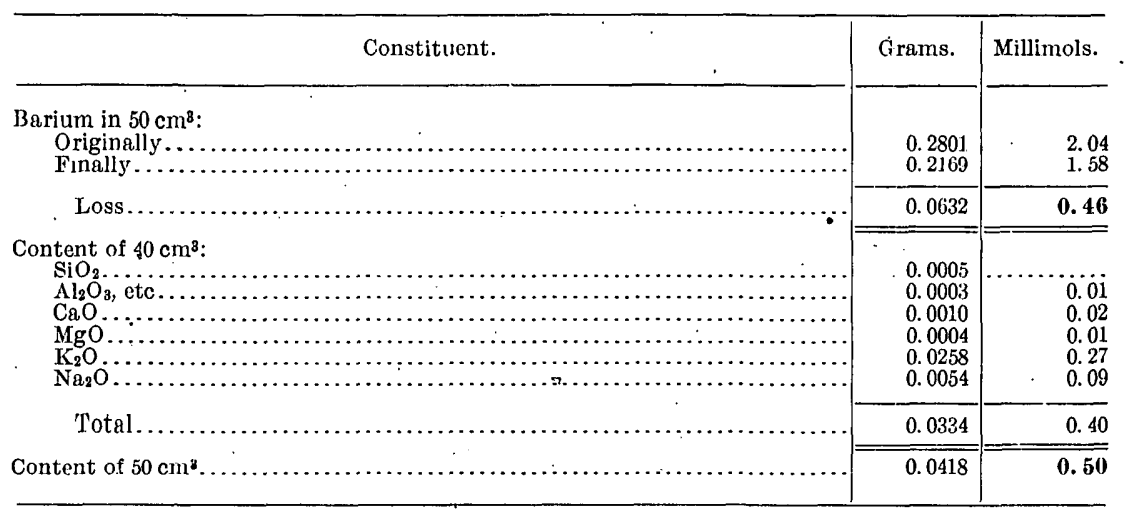

A. S. Cushman has shown ${ }^{a}$ that barium and aluminum are removed to some extent from solutions of their salts by a white china clay.

\section{ORTHOCLASE AND POTASSIUM CHLORIDE.}

Twenty-five grams powdered orthoclase with $50 \mathrm{~cm}^{3}$ potassium chloride solution. Filtered after fourteen days. 'This orthoclase was of a different grinding from that used with other salts, and the precipitation of potassium given below is therefore not directly comparable with that of the other metals.

Experiment with orthoclase and potassium chloride.

\begin{tabular}{|c|c|c|}
\hline Constituent. & Grams. & $\begin{array}{l}\text { Milli- } \\
\text { equiva- } \\
\text { lents. }\end{array}$ \\
\hline 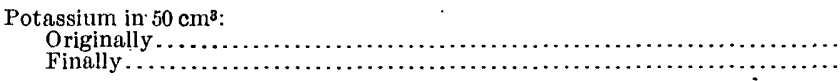 & $\begin{array}{l}0.1558 \\
0.1443\end{array}$ & $\begin{array}{l}3.98 \\
3.69\end{array}$ \\
\hline Loss. & 0.0115 & 0.29 \\
\hline 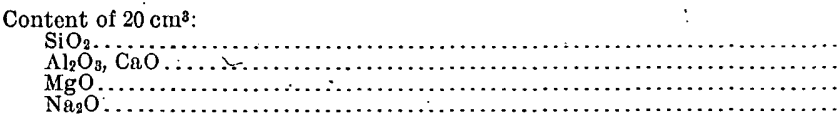 & $\begin{array}{l}0.0004 \\
0.0002 \\
0.0002 \\
0.0086\end{array}$ & $\begin{array}{ll}\cdots \\
0.01 \\
0.14\end{array}$ \\
\hline Total. & 0.0094 & 0.15 \\
\hline Content of $50 \mathrm{~cm}^{3} \ldots$ & 0.0235 & 0.37 \\
\hline
\end{tabular}

$a$ U. S. Dept: Agr., Bureau of Chem., Bull. 92, 1905; p. 18.

Bụll, 312-07-4 
ORTHOCLASE AND SODIUM CHLORIDE.

Fifty $\mathrm{cm}^{3}$ dilute $(0.08 \mathrm{~N})$ sodium chloride solution after contact with 25 grams orthoclase contained about 35 milligrams $\mathrm{K}_{2} \mathrm{O}$ as chloride. $^{a}$

ORTHOCLASE AND SULPHURIC ACID.

Twenty-five grams powdered orthoclase with $50 \mathrm{~cm}^{3} 0.1$ normal sulphuric acid (2.50 millimols).

Oxthoclase and sulphuric acid: content of $40 \mathrm{~cm}^{3}$.

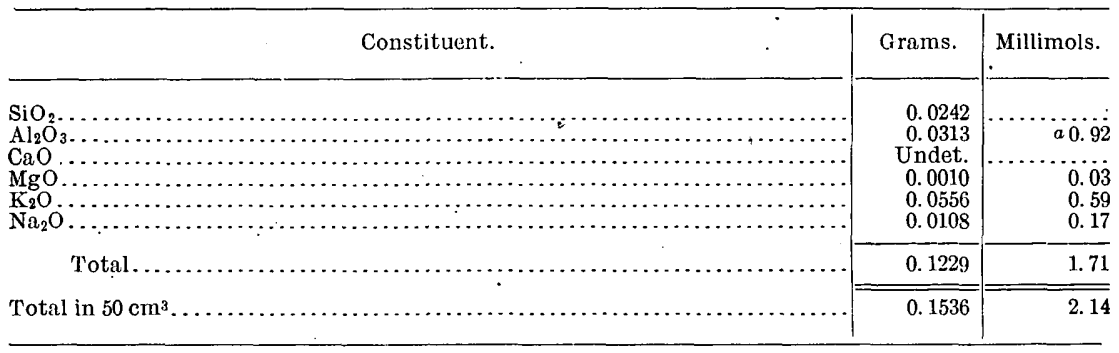

$a$ This is the number of divalent millimols to which 0.0313 gram alumina is equivalent.

The acid has dissolved somewhat less than its own equivalent of bases from the orthoclase. No change in the concentration of the sulphate radical could be detected. Barium sulphate obtained from $40 \mathrm{~cm}^{3}$ before contact with orthoclase 0.4696 gram; after contact, $0.4698 \mathrm{gram}$. Precautions were taken to prevent the precipitation of alkali sulphate with the barium sulphate $;^{b}$ the chlorine carried down was determined and a correction made for it calculated to barium chloride. $^{c}$

The relatively large amount of aluminum dissolved by an acid solution is noticeable as compared with the more nearly neutral salt solutions, which take chiefly the alkali metals from orthoclase. See the results with cupric sulphate in the presence of sulphuric acid and with ferric-sulphate solution, which is quite acid owing to hydrolysis. The salt solutions are similar in this respect to carbonic acid, which, according to Lemberg, ${ }^{a}$ dissolves only the strong bases from silicates, while mineral acids dissolve all bases, including the seśquioxides.

a A. S. Cushman has very recently (U. S. Dept. Agr., Office of Public Roads Circular No. 38, 1906) described experiments showing that the amount of substance dissolved from orthoclase by ammonium chloride solution is decidedly greater than that dissolved by water.

$b$ Hintz and Weber, Zeitsch. anal. Chem., vol. 45, 1906, p. 40; Lunge, G., Zeitsch. für angew. Chem., Heft. 12, 1905.

c Hulett, G. A., and Duschak, L. H., Zeits. für anorg. Chem., vol. 40, 1904, p. 196.

$d$ Zeitsch. deutsch. geol. Gesell., vol. 28, 1876, p. 595. 
ORTHOCLASE AND CARBONIC ACID.

Twenty grams orthoclase A taken with $50 \mathrm{~cm}^{3}$ water, carbon dioxide passed through the mixture for twenty hours. The solution contained 0.040 gram of solid. Dilute cupric-sulphate solution dissolved about 0.065 gram from the same quantity of this orthoclase, and water less than 0.010 gram. $^{a}$

\section{MICROCLINE AND CUPRIC SULPHATE.}

Twenty-five grams powdered microcline, $\mathrm{KAlSi}_{3} \mathrm{O}_{8}$, from Way's quarry, near Wilmington, Del., containing 0.03 per cent $\mathrm{CO}_{2}(=$ 0.0075 gram or 0.17 millimol carbon dioxide in 25 grams feldspar) with $50 \mathrm{~cm}^{3}$ cupric sulphate solution containing 0.126 gram ( 2 millimols) copper. Filtered after twenty-four hours. The filtrate had lost approximately 0.100 gram (1.6 millimols) copper from $50 \mathrm{~cm}^{3}$.

\section{ALBITE AND CUPRIC SULPHATE.}

Albite, $\mathrm{NaAlSi}_{3} \mathrm{O}_{8}$, containing 0.02 per cent $\mathrm{CO}_{2}(=0.005$ gram or 0.11 millimol $\mathrm{CO}_{2}$ in 25 grams feldspar) in contact over night with cupric sulphate solution.

Experiment with albite and cupric sulphate.

\begin{tabular}{|c|c|c|}
\hline Constituent. & Grams. & Millimols. \\
\hline $\begin{array}{l}{\text { Copper in } 50 \mathrm{~cm}^{3}:} \\
\text { Originally } \ldots \ldots \ldots \ldots \ldots \ldots \ldots \ldots \\
\text { Finally } \ldots \ldots \ldots \ldots \ldots \ldots \ldots \ldots\end{array}$ & $\begin{array}{l}0.1266 \\
0.0343\end{array}$ & $\begin{array}{l}1.99 \\
0.54\end{array}$ \\
\hline Loss ................... & 0.0923 & 1.45 \\
\hline 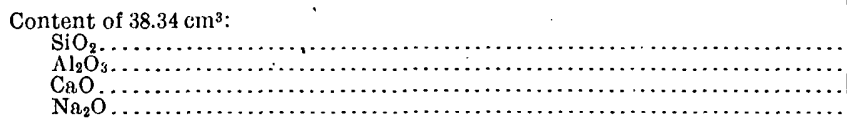 & $\begin{array}{r}0.0046 \\
0.0020 \\
0.0107 \\
a 0.0516\end{array}$ & $\begin{array}{l}0.06 \\
0.19 \\
0.83\end{array}$ \\
\hline Total..... & 0.0689 & 1.08 \\
\hline Content of $50 \mathrm{~cm} .^{3} \ldots \ldots \ldots$ & 0.0898 & $\overline{1.41}$ \\
\hline
\end{tabular}

a Including a little $\mathrm{MgO}$ and $\mathrm{K}_{2} \mathrm{O}$.

The albite after this treatment was washed and dried (it had a bluish-green tinge) and again subjected to the action of cupric sulphate solution.

Copper found in $50 \mathrm{~cm}^{3}$ of cupric sulphate solution with albite.

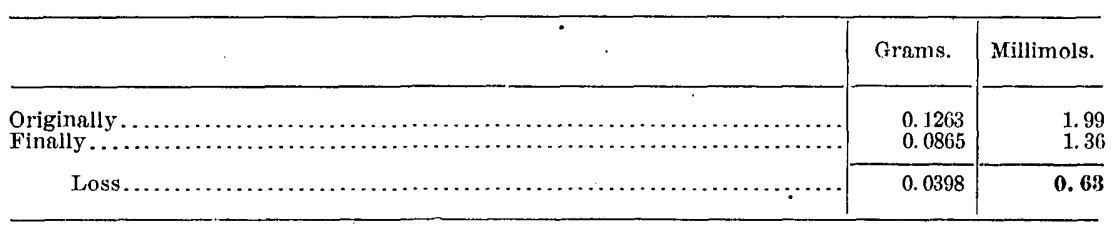

a For the action of carbonic acid solution on various minerals see W. B. and R. E. Rogers, Am. Jour. Sci., 2d ser., vol. 5, 1848, p. 401, and R. Müller, Tschermaks Min. Pet. Mitt, 1877, p. 25. 
ENSTATITE AND CUPRIC SULPHATE.

Twenty grams powdered enstatite (bronzite) $(\mathrm{MgFe})_{2}\left(\mathrm{SiO}_{3}\right)_{2}$, from Webster, Jackson County, N. C., removed the color at once from 50 $\mathrm{cm}^{3}$ dilute cupric sulphate solution: $9 \mathrm{~cm}^{3}$ concentrated solution were then added, so that cupric sulphate was finally in excess.

Experiment with enstatite and cupruc sulphate.

\begin{tabular}{|c|c|c|c|c|}
\hline Constituent. & Grams. & Millimols. & Grams. & Millimols. \\
\hline $\begin{array}{l}\text { Copper in } 59 \mathrm{~cm}^{3}: \\
\text { Originally } \ldots \ldots \ldots \\
\text { Finally } \ldots \ldots \ldots \ldots\end{array}$ & $\begin{array}{l}0.6620 \\
0.2246\end{array}$ & $\begin{array}{r}10.41 \\
3.53\end{array}$ & $\begin{array}{l}0.6620 \\
0.2274\end{array}$ & $\begin{array}{r}10.41 \\
3.58\end{array}$ \\
\hline Loss.. & $0 . \overline{4374}$ & 6.88 & 0.4346 & 6.83 \\
\hline 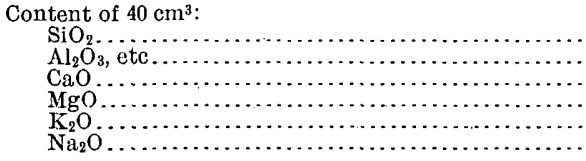 & $\cdots$ & $\begin{array}{c}\cdots \\
\cdots \cdots \\
\cdots \cdots\end{array}$ & $\begin{array}{r}0.0035 \\
0.0003 \\
0.0183 \\
0.1159 \\
.0 .0007 \\
0.0010\end{array}$ & $\begin{array}{l}0.01 \\
0.33 \\
2.85 \\
0.01 \\
0.02\end{array}$ \\
\hline Total......... & $\cdots$ & - & 0.1388 & 3.22 \\
\hline Content of $59 \mathrm{~cm}^{3}$. & & .. & 0.2052 & 4.76 \\
\hline
\end{tabular}

In each of the experiments with enstatite the inner surface of the flask became coated with very fine grains which under the mircoscope appeared rounded. They were insoluble in water, soluble in dilute acid, and contained copper and sulphate, hence basic sulphate of copper.

\section{AUGITE AND CUPRIC SULPHATE.}

Augite, $\mathrm{Ca}(\mathrm{Mg} ; \mathrm{Fe}) \mathrm{Si}_{2} \mathrm{O}_{6}$, from Herschell Township, Hastings County, Ontario. Extracted with dilute hydrochloric acid before powdering. As used contained 0.28 per cent $\mathrm{CO}_{2},=0.07$ gram or 1.59 millimols $\mathrm{CO}_{2}$ in 25 grams augite. Twenty-five grams of the finely ground mineral removed the color completely from $50 \mathrm{~cm}^{3}$ dilute cupric sulphate solution: $4 \mathrm{~cm}^{3}$ of concentrated solution were added, and cupric sulphate was then in excess.

Experiment with augite and cupric sulphate.

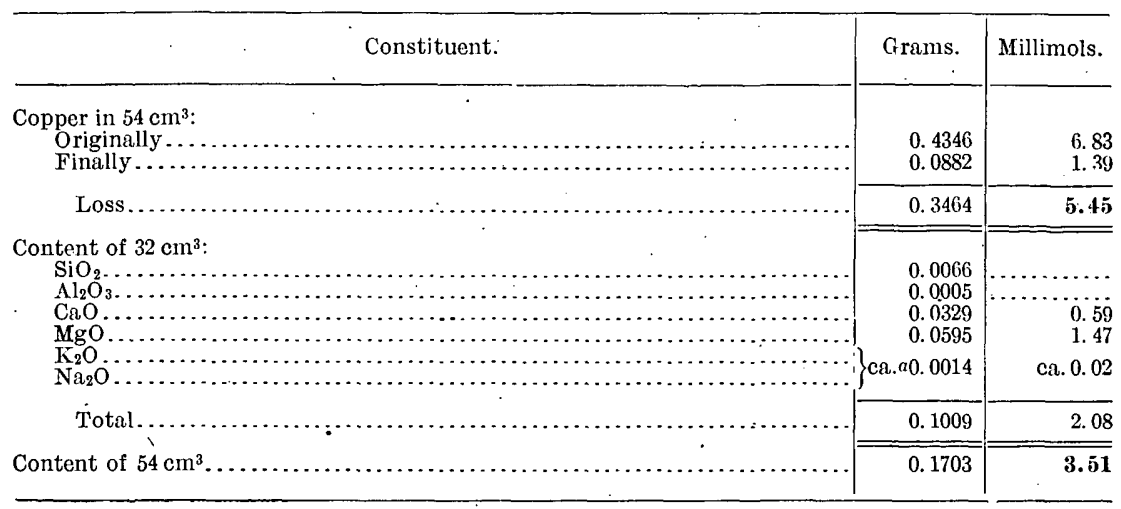


Here more $\mathrm{SO}_{4}$ has left the solution than corresponds to the formula $\mathrm{Cu}_{4}(\mathrm{OH})_{3} \mathrm{SO}_{4}$. This was confirmed by a direct determination of $\mathrm{SO}_{4}$ in an $8 \mathrm{~cm}^{3}$ portion of the filtrate after removal of the copper. Barium sulphate obtained was 0.1688 gram, as against 0.2379 gram from the same volume originally, a loss of $0.0691 \mathrm{gram}$ in $8 \mathrm{~cm}^{3}$, equivalent to a loss of 2 millimols $\mathrm{SO}_{4}$ from $54 \mathrm{~cm}^{3}$.

Of the total copper precipitated, 5.45 millimols, about 2.12 millimols are ascounted for by the carbonate present.

\section{ANTHOPHYLLITE AND CUPRIC SULPHATE.}

Twenty-five grams powdered anthophyllite $(\mathrm{Mg}, \mathrm{Fe}) \mathrm{SiO}_{3}$, from Upper Providence, Delaware County, Pa., removed the copper completely from $50 \mathrm{~cm}^{3}$ dilute cupric sulphate solution. Fifteen $\mathrm{cm}^{3}$ concentrated solution was then added, so that cupric sulphate was finally in excess. Filtered after eleven days:

Experiment with anthophyllite and cupric sulphate.

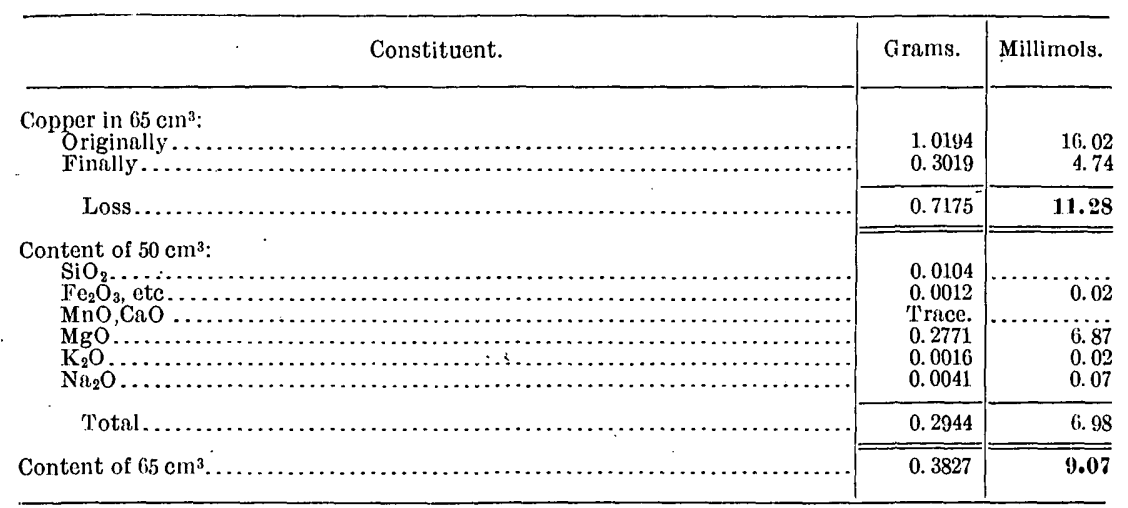

AMPHIBOLE AND CUPRIC SULPHATE.

Twenty grams powdered amphibole, $\mathrm{Ca}(\mathrm{Mg}, \mathrm{Fe})_{3}\left(\mathrm{SiO}_{3}\right)_{4}$, from St. Lawrence County, N. Y., removed the color completely from $40 \mathrm{~cm}^{3}$ dilute cupric sulphate solution. In the first experiment impurities had been separated as far as possible from the amphibole, before fine grinding, by means of Thoulet solution; in the second such purification was not attempted. Filtered after twenty-four hours' contact. 
Experiment with amphibole and cupric sulphate.

\begin{tabular}{|c|c|c|c|c|}
\hline Constituent. & Grams. & Millimols. & Grams. & Millimols. \\
\hline $\begin{array}{l}\text { Copper in } 40 \mathrm{~cm}^{3}: \\
\text { Originally } \ldots . . \\
\text { Finally } . . . . .\end{array}$ & $\begin{array}{r}0.1015 \\
0\end{array}$ & 1. 60 & $\begin{array}{r}0.1015 \\
0\end{array}$ & $\begin{array}{r}1.60 \\
0\end{array}$ \\
\hline Loss.. & 0.1015 & 1.60 & 0.1015 & 1.60 \\
\hline Content of filtrate: & \multicolumn{2}{|c|}{$24.4 \mathrm{~cm}^{3}$} & \multicolumn{2}{|c|}{$30 \mathrm{~cm}^{3}$} \\
\hline $\begin{array}{l}\mathrm{SiO}_{2} \ldots \ldots \ldots \ldots \\
\mathrm{Fe}_{2} \mathrm{O}_{3} \ldots \ldots \ldots \ldots \\
\mathrm{CaO} \ldots \ldots \ldots \\
\mathrm{MgO}^{\mathrm{K}_{2} \mathrm{O}} \ldots \ldots \ldots \ldots \\
\mathrm{N}_{2} \mathrm{O} \ldots \ldots \ldots\end{array}$ & $\begin{array}{l}0.0009 \\
0.0003 \\
0.0042 \\
0.0369 \\
0.0049 \\
0.0089\end{array}$ & $\begin{array}{l}0.01 \\
0.08 \\
0.92 \\
0.05 \\
0.14\end{array}$ & $\begin{array}{l}0.0001 \\
0.0006 \\
0.0089 \\
0.0471 \\
0.0183 \\
0.0063\end{array}$ & $\begin{array}{l}0.02 \\
0.16 \\
1.17 \\
0.19 \\
0.10\end{array}$ \\
\hline Total. . & 0.0561 & 1.20 & 0.0813 & 1.64 \\
\hline Content of $40 \mathrm{~cm}^{3}$. & 0.0920 & 1.97 & 0.1084 & 2.19 \\
\hline
\end{tabular}

GARNET ·AND CUPRIC SULPHATE.

Twenty grams powdered garnet, $\mathrm{Ca}_{3} \mathrm{Al}_{2} \mathrm{Si}_{3} \mathrm{O}_{12}$; from Burke County, N. C., with $40 \mathrm{~cm}^{3}$ dilute cupric sulphate solution. The garnet had been ground to about 100-mesh and separated from other minerals by means of Thoulet solution before it was finely pulverized. Filtered after three days.

Experiment with garnet and cupric sulphate.

\begin{tabular}{|c|c|c|}
\hline Constituent. & Grams. & Millimols. \\
\hline $\begin{array}{l}\text { Copper in } 40 \mathrm{~cm}^{3} \text { : } \\
\quad \text { Originally } \ldots \ldots \ldots \ldots \ldots \ldots \\
\text { Finally } \ldots \ldots \ldots \ldots \ldots \ldots\end{array}$ & $\begin{array}{l}0.1010 \\
0.0569\end{array}$ & $\begin{array}{l}1.59 \\
0.89\end{array}$ \\
\hline Loss... & 0.0441 & 0.70 \\
\hline 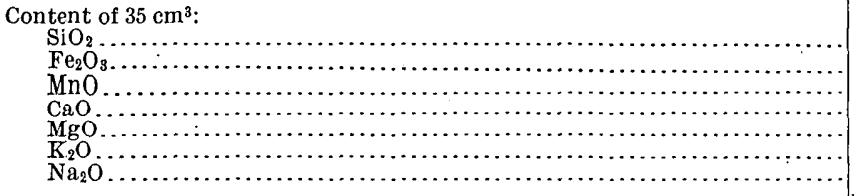 & $\begin{array}{l}0.0037 \\
0.0012 \\
0.0060 \\
0.0016 \\
0.0076 \\
0.0039 \\
0.0011\end{array}$ & $\begin{array}{l}0.02 \\
0.09 \\
0.03 \\
0.19 \\
0.04 \\
0.02\end{array}$ \\
\hline Total. & 0.0251 & 0.39 \\
\hline Content of $40 \mathrm{~cm}^{3}$. & 0.0287 & 0.45 \\
\hline
\end{tabular}

OLIVINE AND CUPRIC SULPHATE.

Chrysolite (olivine) $(\mathrm{Mg}, \mathrm{Fe})_{2} \mathrm{SiO}_{4}$, from Webster, Jackson County, N. C., extracted with dilute hydrochloric acid before powdering. As used contains 0.32 per cent $\mathrm{CO}_{2}$, equal to 0.08 gram or 1.82 millimols $\mathrm{CO}_{2}$ in 25 grams. This amount of carbonate would precipitate about 2.43 millimols copper. Twenty-five grams olivine removed the color at once from $50 \mathrm{~cm}^{3}$ dilute cupric sulphate solution; $4 \mathrm{~cm}^{3}$ concentrated solution were added, so that cupric sulphate was finally in excess in the solution. 
Experiment with olivine and cupric sulphate. .

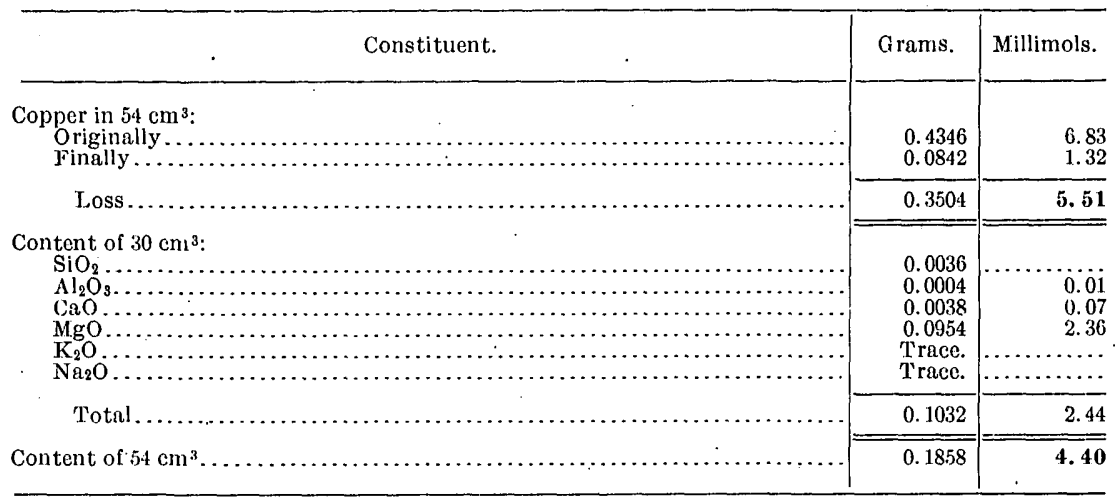

VESUVIANITE AND CUPRIC SULPHATE.

Twenty grams powdered vesuvianite, $\mathrm{Ca}_{6}(\mathrm{Al}, \mathrm{Fe})_{3}(\mathrm{OH}, \mathrm{F})\left(\mathrm{SiO}_{4}\right)_{5}$, from Sanford, Me., removed the color completely from $40 \mathrm{~cm}^{3}$ dilute cuṕric sulphate solution. Filtered after two days' contact. Filtrate neutral or faintly alkaline to litmus.

Experiment with vesuvianite and cupric sulphate.

\begin{tabular}{|c|c|c|}
\hline Constituent. & Grams. & Millimols. \\
\hline $\begin{array}{l}\text { Copper in } 40 \mathrm{~cm}^{3} \text { : } \\
\quad \text { Originally } \ldots \ldots \ldots \ldots \ldots \ldots \ldots \ldots \\
\text { Finally } \ldots \ldots \ldots \ldots \ldots \ldots \ldots \ldots\end{array}$ & $\begin{array}{l}0.1012 \\
0\end{array}$ & $\begin{array}{l}1.59 \\
0\end{array}$ \\
\hline Loss.... & 0.1012 . & 1. 59 \\
\hline 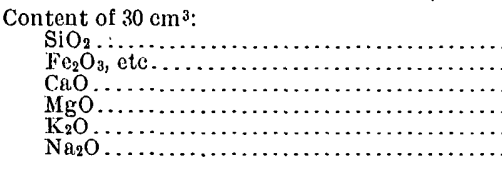 & $\begin{array}{l}0.0001 \\
0.0010 \\
0.0505 \\
0.0076 \\
0.0003 \\
0.0009\end{array}$ & $\begin{array}{l}0.02 \\
0.90 \\
0.1 .9 \\
0.003 \\
0.02\end{array}$ \\
\hline Total....... & 0.0604 & 1.13 \\
\hline Content of $40 \mathrm{~cm}^{3}$. . & 0.0805 & 1.51 \\
\hline
\end{tabular}

EPIDOTE AND CUPRIC. SULPHATE.

Twenty-five grams powdered epidote, $\mathrm{HCa}_{2}(\mathrm{Al}, \mathrm{Fe})_{3} \mathrm{Si}_{3} \mathrm{O}_{13}$, " from Germany," removed the color completely from $50 \mathrm{~cm}^{3}$ dilute cupric sulphate solution; $5 \mathrm{~cm}^{3}$ concentrated solution were afterwards added, so that copper sulphate was finally in excess in the solution. Filtered after nine days. Basic copper sulphate was deposited on the flask wall. 
Experiment with epidote and cupric sulphate.

\begin{tabular}{|c|c|c|}
\hline Constituent. & Grams. & Millimols. \\
\hline $\begin{array}{l}\text { Copper in } 55 \mathrm{~cm}^{3}: \\
\quad \\
\quad \text { Originally } \ldots \ldots \ldots \ldots \ldots \ldots \ldots \\
\quad \text { Finally } \ldots \ldots \ldots \ldots \ldots \ldots \ldots\end{array}$ & $\begin{array}{l}0.4238 \\
0.0705\end{array}$ & $\begin{array}{l}6.67 \\
1.11 \\
\end{array}$ \\
\hline Loss.. & 0.3533 & 5.56 \\
\hline 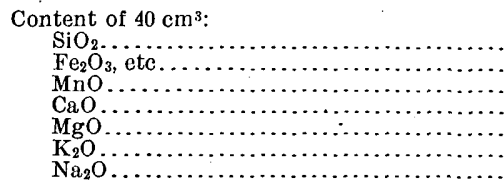 & $\begin{array}{l}0.0039 \\
0.0012 \\
0.0046 \\
0.0317 \\
0.0177 \\
0.0017 \\
0.0036\end{array}$ & $\begin{array}{l}\dddot{0.02} \\
0.06 \\
0.57 \\
0.44 \\
0.02 \\
0.06\end{array}$ \\
\hline Total.. & 0.0644 & 1.17 \\
\hline Content of $55 \mathrm{~cm}^{3} \ldots$ & 0.0886 & $1.61(?)$ \\
\hline
\end{tabular}

PREHNITE AND CUPRIC SULPHATE.

Twenty-five grams prehnite, $\mathrm{H}_{2} \mathrm{Ca}_{2} \mathrm{Al}_{2} \mathrm{Si}_{3} \mathrm{O}_{12}$, from Upper Montclair, N. J., removed the color from $50 \mathrm{~cm}^{3}$ cupric sulphate solution containing 0.126 gram copper.

\section{TOURMALINE AND CUPRIC SULPHATE.}

Black tourmaline, Pierrepont, St. Lawrence County, N. Y.; 20 grams removed the color completely from $40 \mathrm{~cm}^{3}$ cupric sulphate solution containing 0.1 gram copper. Filtered after twenty-four hours. The filtrate was neutral to litmus and contained boron.

\section{MUSCOVITE AND CUPRIC SULPHATE.}

Twenty-five grams muscovite, $\mathrm{H}_{2} \mathrm{KAl}_{3} \mathrm{Si}_{3} \mathrm{O}_{12}$, from Jackson County, $\mathrm{N}$. C., containing 0.026 per cent $\mathrm{CO}_{2}$, equal to 0.0065 gram or 0.15 millimol $\mathrm{CO}_{2}$ in the 25 grams, removed the color completely at once from $50 \mathrm{~cm}^{3}$ dilute cupric sulphate solution; $4 \mathrm{~cm}^{3}$ concentrated solution were added, furnishing an excess of cupric sulphate to the solution.

Experiment with muscovite and cupric sulphate.

\begin{tabular}{|c|c|c|c|}
\hline . & Constituent. & Grams. & Millimols. \\
\hline $\begin{array}{l}\text { Copper in } 54 \mathrm{~cm}^{3}: \\
\text { Originally } \ldots \ldots \\
\text { Finally } . . . . . .\end{array}$ & & $\begin{array}{l}0.4346 \\
0.1632\end{array}$ & $\begin{array}{l}6.83 \\
2.55\end{array}$ \\
\hline Loss... & & 0.2714 & 4.27 \\
\hline 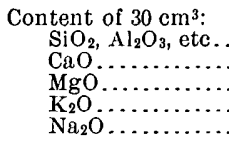 & - & $\begin{array}{l}0.0019 \\
0.0013 \\
0.0084 \\
0.1203 \\
0.0209\end{array}$ & $\begin{array}{l}0.02 \\
0.21 \\
1.28 \\
0.34\end{array}$ \\
\hline Total.... & & 0.1528 & 1.85 \\
\hline Content of $54 \mathrm{~cm}^{3}$. . & & 0.2750 & $\overline{3.33}$ \\
\hline
\end{tabular}




\section{BIOTITE AND CUPRIC SULPHATE.}

Biotite, $(\mathrm{HK})_{2}(\mathrm{Mg}, \mathrm{Fe})_{2}(\mathrm{Al}, \mathrm{Fe})_{2} \mathrm{Si}_{3} \mathrm{O}_{12}$, from Rossie County, N. Y., containing 0.15 per cent $\mathrm{CO}_{2},=0.038$ gram or 0.86 millimol $\mathrm{CO}_{2}$ in 25 grams biotite. Twenty-five grams removed the color at once from $50 \mathrm{~cm}^{3}$ dilute cupric sulphate solution; $4 \mathrm{~cm}^{3}$ concentrated solution were then added, making cupric sulphate in excess.

Experiment with biotite and cupric sulphate.

\begin{tabular}{|c|c|c|}
\hline Constituent. & Grams. & Millimols. \\
\hline 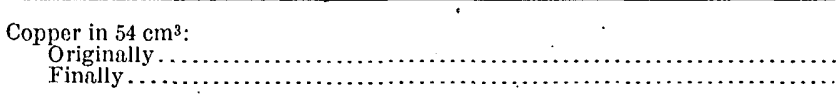 & $\begin{array}{l}0.4346 \\
0.2246\end{array}$ & $\begin{array}{l}6.83 \\
3.53\end{array}$ \\
\hline I.oss... & 0.2100 & 3.30 \\
\hline 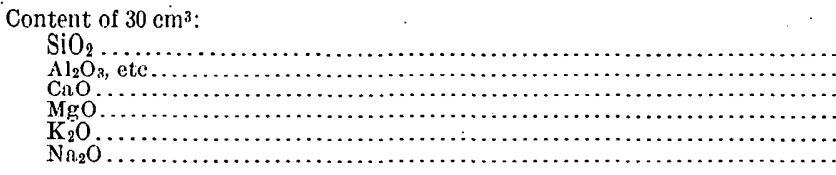 & $\begin{array}{r}0.0027 \\
0.0032 \\
\text { Tr. } \\
0.0635 \\
0.0443 \\
0.0046\end{array}$ & $\begin{array}{l}0.09 \\
1.57 \\
0.47 \\
0.07\end{array}$ \\
\hline Total. . & 0.1183 & 2.20 \\
\hline Content of $54 \mathrm{~cm}^{3}$. & 0.2129 . & 3.96 \\
\hline
\end{tabular}

The bases removed are here in excess of the copper precipitated, and it was found that water alone extracted a considerable quantity of material from the powdered mineral.

\section{TALC AND CUPRIC SULPHATE.}

Twenty grams powdered talc $\left(\mathrm{H}_{2} \mathrm{Mg}_{3} \mathrm{Si}_{4} \mathrm{O}_{12}\right)$, from Harford County, $\mathrm{Md}$., removed the copper almost completely from $40 \mathrm{~cm}^{3}$ dilute cupric sulphate solution. Filtered after three days.

Experiment with talc and cupric sulphate.

\begin{tabular}{|c|c|c|}
\hline Constituent. & Grams. & Millimols. \\
\hline $\begin{array}{l}\text { Copper in } 40 \mathrm{~cm}^{3}: \\
\quad \text { Originally } \ldots \ldots \ldots \ldots \ldots \ldots \ldots \ldots \ldots \ldots \ldots \ldots \ldots\end{array}$ & $\begin{array}{r}0.1010 \\
a \mathrm{Tr} .\end{array}$ & $\begin{array}{l}1.59 \\
\text { Tr. }\end{array}$ \\
\hline Loss... & 0.1 & 1.5 \\
\hline 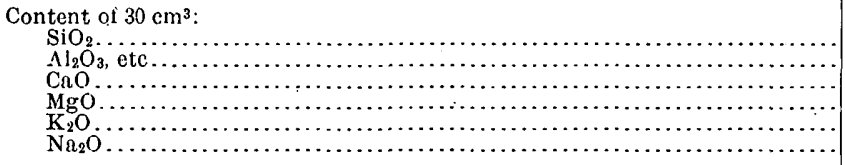 & $\begin{array}{l}0.0046 \\
0.0003 \\
0.0018 \\
0.0387 \\
0.0005 \\
0.0005\end{array}$ & $\begin{array}{l}0.01 \\
0.03 \\
0.96 \\
0.01 \\
0.01\end{array}$ \\
\hline Total. . & 0.0464 & 1.02 \\
\hline Content of $40 \mathrm{~cm}^{3} \ldots \ldots \ldots \ldots$ & 0.0619 & 1.36 \\
\hline
\end{tabular}




\section{SHALE AND CUPRIC SULPHATE.}

A shale from Newtown, Ariz. ("Morenci shale"), finely pulverized in an agate mortar and mixed with twice its weight of solution. The shale was made up chiefly of kaolin, glauconite, and epidote, and contained 6.74 per cent $\mathrm{K}_{2} \mathrm{O}$ and 0.44 per cent $\mathrm{Na}_{2} \mathrm{O}$.

Experiments with shale and cupric sulphate.

COPPER IN 50 CUBIC CENTIMETERS.

\begin{tabular}{|c|c|c|c|c|c|c|}
\hline & \multicolumn{2}{|c|}{1.} & \multicolumn{2}{|c|}{2.} & \multicolumn{2}{|c|}{3.} \\
\hline & Grams. & Millimols. & Grams. & Millimols. & Ġrams. & Millimols. \\
\hline $\begin{array}{l}\text { Originally ........ } \\
\text { Finally ............ }\end{array}$ & $\begin{array}{l}0.1277 \\
0.0063\end{array}$ & $\begin{array}{l}2.01 \\
0.10\end{array}$ & $\begin{array}{r}1 \quad 0.1277 \\
0\end{array}$ & $\begin{array}{r}2.01 \\
0\end{array}$ & $\begin{array}{l}3.747 \\
3.584\end{array}$ & $\begin{array}{l}58.91 \\
56.35\end{array}$ \\
\hline Loss.. & 0.1214 & 1.91 & 0.1277 & 2.01 & 0.163 & 2.56 \\
\hline
\end{tabular}

CONTEN'TS OF FILTRATES.

\begin{tabular}{|c|c|c|c|c|c|c|}
\hline Constituent. & & $\mathrm{cm}^{3}$ & 82.6 & $\mathrm{~cm}^{3}$ & & \\
\hline 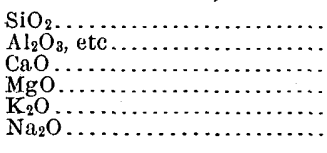 & $\begin{array}{l}0.0053 \\
0.0010 \\
0.0247 \\
0.0518 \\
0.0840 \\
0.0035 \\
\end{array}$ & $\begin{array}{r}0.03 \\
0.44 \\
1.28 \\
0.89 \\
0.06 \\
\end{array}$ & $\begin{array}{l}0.0011 \\
0.0036 \\
0.0185 \\
0.0754 \\
0.0625 \\
0.0046 \\
\end{array}$ & $\begin{array}{l}0.12 \\
0.33 \\
1.88 \\
0.66 \\
0.07\end{array}$ & 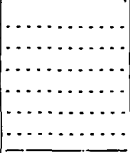 & 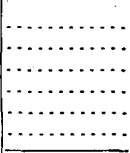 \\
\hline $\begin{array}{r}\text { Total } \ldots \ldots \ldots \ldots \ldots \ldots \\
\text { Content of } 50 \mathrm{~cm}^{3} \ldots \ldots \ldots \ldots \ldots\end{array}$ & $\begin{array}{l}0.1703 \\
0.1565\end{array}$ & $\begin{array}{r}2.70 \\
1.69\end{array}$ & $\begin{array}{l}0.1657 \\
0.1003\end{array}$ & $\begin{array}{r}3.06 \\
1.85\end{array}$ & & \\
\hline
\end{tabular}

Contact in the first experiment was for a few days, in the second for four months, and in the third for a few hours. The dilute solutions were neutral to litmus after contact with the shale.

The microscopic examination was made by Mr. W. Lindgren of the Geological Survey,- at whose suggestion the action of the shale toward cupric sulphate solution was examined. The chemical analysis was by Dr. W. F. Hillebrand, of the Geological Survey. The occurrence of cuprite in this shale is common at Morenci. ${ }^{a}$

\section{CLAY GOUGE WITH CUPRIC SULPHATE.}

Clay gouge vein-filling from Silver Plume, Colo. Contains 3.92 per cent $\mathrm{CO}_{2}(=0.784$ gram or 17.84 millimols in 20 grams), largely as ferrous carbonate; 3.52 per cent $\mathrm{K}_{2} \mathrm{O}, 0.18$ per cent $\mathrm{Na}_{2} \mathrm{O}$. Ground in agate mortar. Twenty grams taken with $40 \mathrm{~cm}^{3}$ concentrated cupric sulphate solution. Filtered after three days.

Experiment with clay gouge and cupruc sulphate.

\begin{tabular}{|c|c|c|c|}
\hline \multicolumn{2}{|r|}{ Constituent. } & Grams. & Millimols. \\
\hline $\begin{array}{r}\text { Copper in } 40 \mathrm{~cm}^{3}: \\
\text { Originally } \ldots \\
\text { Finally } . . . .\end{array}$ & & $\begin{array}{l}2.382 \\
2.091\end{array}$ & $\begin{array}{l}3.75 \\
3.29\end{array}$ \\
\hline Loss... & & 0.291 & 0.46 \\
\hline
\end{tabular}

$a$ See Lindgren, Prof. Paper U. S. Geol. Survey, No. 43, p. 191. 
The bases dissolved from the gouge were chiefly alumina and potash. The ferrous carbonate appears to have taken little if any part in the precipitation of the copper, in contrast with the action of the more soluble calcium carbonate, which is completely dissolved by cupric sulphate solution (see p. 84).

\section{CLAY GOUGE WITH SILVER SULPHATE.}

Twenty grams of the finely ground material taken with $40 \mathrm{~cm}^{3}$ silver sulphate solution. Filtered after four days.

Experiment with clay gouge and silver sulphate:

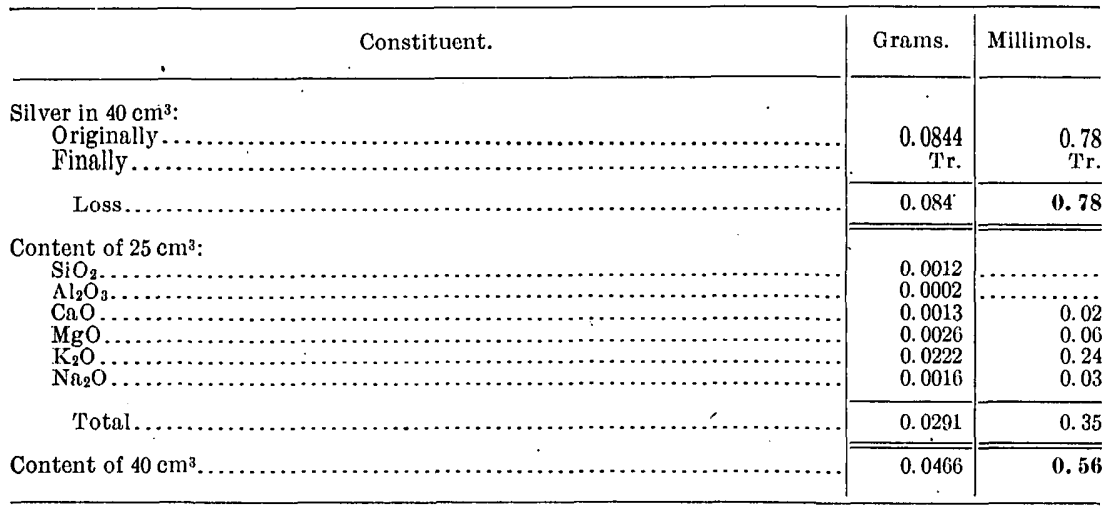

The filtrate gave no reaction for ferric salt with potassium'sulphocyanate nor for ferrous with ferricyanide. Again the ferrous carbonate apparently had not been affected.

Work with this material was made possible through the kindness of Mr. G. H. Garrey, who placed samples at the writer's disposal.

\section{CALCITE (ICELAND SPAR) AND CUPRIC SULPHATE.}

$0.0502 \operatorname{gram}(=0.502$ millimol $)$ calcite in contact with $50 \mathrm{~cm}^{3}$ dilute cupric sulphate solution. Filtered after two days.

Calcite and cupric sulphate: content of $50 \mathrm{~cm}^{3}$.

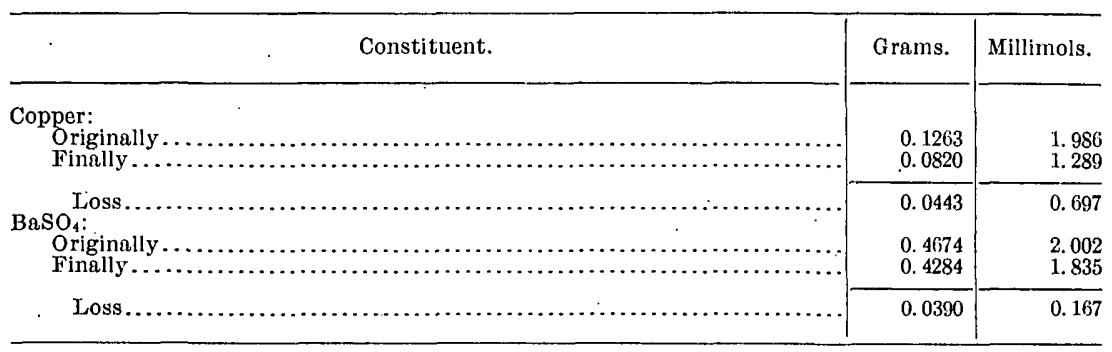

The loss of copper is to the loss of sulphate as $4: 0.96$, indicating the precipitation of a basic sulphate similar in composition to brochantite 
and langite. This is in accordance with the work of Becquerel. ${ }^{a}$ The precipitate contained no calcium. Brochantite varies in composition from $\mathrm{CuSO}_{4}, 5 / 2 \mathrm{CuO}, 3 \mathrm{H}_{2} \mathrm{O}$ to $\mathrm{CuSO}_{4}^{-}, 7 / 2 \mathrm{CuO}$, aq. Moissan, Traité, 5,83 .

\section{FLUORITE AND CUPRIC SULPHATE.}

Fluorite removed practically no copper at all from dilute cupric sulphate solution.

\section{PYRITE AND CUPRIC SULPHATE.}

Ground pyrite ('25 grams) washed with sulphuric acid, alcohol, and ether removed 0.0286 gram copper from $50 \mathrm{~cm}^{3}$ cupric sulphate solution containing originally 0.1263 gram copper.

GLASS AND CUPRIC SULPHATE.

One hundred $\mathrm{cm}^{3} 1$ per cent cupric sulphate solution in contact ten days with 71 grams coarsely powdered window glass.

Glass and cupric sulphate: content of $50 \mathrm{~cm}^{3}$.

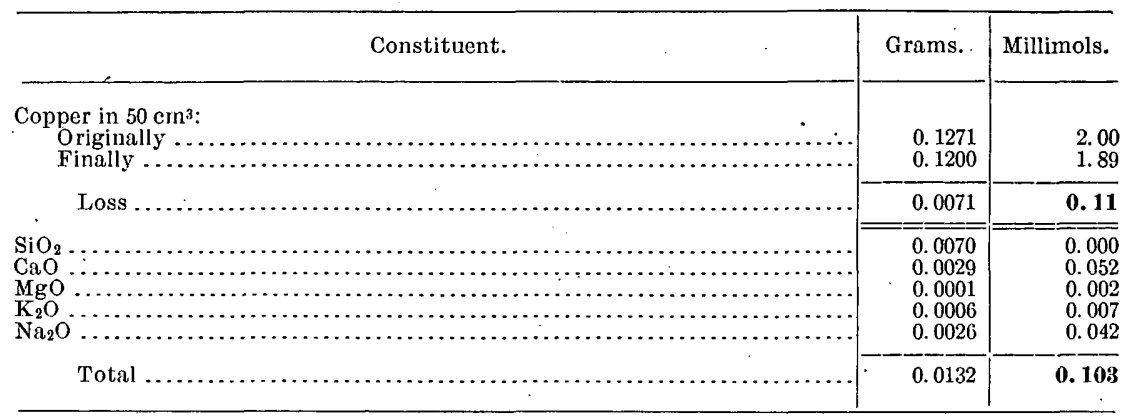

The glass, after washing with water until the washings no longer contained copper, retained a green color, unmistakable on comparison with the original glass. Extraction with hydrochloric acid gave a solution from which 0.0056 gram copper and 0.0057 gram barium sulphate were obtained, i. e., $4 \mathrm{Cu}: 1.1 \mathrm{SO}_{4}$.

An accumulation of sediment in the stock bottle of 1 per cent cupric sulphate solution gave 0.0083 gram copper and 0.0084 gram barium sulphate, again $4 \mathrm{Cu}: 1.1 \mathrm{SO}_{4}$. Contact with a silicate precipitates in these cases, therefore, the same basic sulphate which results on treating cupric sulphate solution with insufficient alkali for complete precipitation.

\section{POSSIBLE APPLICATION TO GEOLOGIC PHENOMENA.}

What part these reactions have actually played in ore deposition and other geologic changes is for the geologist to decide. Lindgren ${ }^{b}$

a Comptes rendus, vol. 34,1852 , p. 573 .

$b$ Copper deposits of the Clifton-Morenci district, Arizona: Prof. Paper U. S. Geol. Survey No. 43, 1905, p. 119. 
has recently noted the fact that the basic copper sulphate, brochantite, whose composition is that of one of the substances formed by the action of silicates on copper-salt solutions, is an ore of more frequent occurrence than is usually supposed, it having been confounded in many cases with chrysocolla or malachite. The sulphide ores could readily result from such basic compounds through reduction of the sulphate by organic matter or by other oxidizable substances. The change from the cupric to the more commonly found cuprous compounds, such as cuprite and chalcocite, could be due to the same reducing agents or even to hydrogen sulphide. Cuprous sulphide appears to be more stable than cupric sulphide at high temperatures, and it may well be more stable at lower temperatures also. A cupric salt precipitated by hydrogen sulphide under ordinary conditions forms some cuprous sulphide-for example, $2 \mathrm{CuSO}_{4}+2 \mathrm{H}_{2} \mathrm{~S}=\mathrm{Cu}_{2} \mathrm{~S}+\mathrm{S}+$ $2 \mathrm{H}_{2} \mathrm{SO}_{4}$, in addition to the cupric sulphide which makes up the main mass of the precipitate, that is, $\mathrm{CuSO}_{4}+\mathrm{H}_{2} \mathrm{~S}=\mathrm{CuS}+\mathrm{H}_{2} \mathrm{SO}_{4}$.

As illustrating further the reducibility of cupric compounds by hydrogen sulphide, cupric sulphide when dissolved in hydrochloric acid forms cuprous chloride $-2 \mathrm{CuS}+2 \mathrm{HCl}=2 \mathrm{CuCl}+\mathrm{H}_{2} \mathrm{~S}+\mathrm{S}$. This reaction is mentioned by "Gmelin-Kraut ${ }^{a}$ and has been confirmed by the writer.

\section{FORM OF PRECIPITATION.}

The immediate condition in which the metal is thrown down from the solution by a silicate is perhaps of secondary importance, subject as the newly formed substance is to spontaneous change into a more stable form, as from amorphous or colloidal to crystalline in structure, and also to the modifying and transforming influence of continually renewed portions of active solutions. The fact of prime significance geologically seems to be that by a process of simple chemical exchange the metal may be removed from solution and fixed in the solid state and thus concentrated, by contact with even the most stable of the silicates.

The changes under consideration involve the action of the alkali or alkaline-earth salt of a weak acid (silicic or alumino-silicic) and are thus analogous to the more familiar behavior of sodium carbonate with solutions of salts of the metals. Owing to hydrolysis the precipitates caused by sodium carbonate tend to split up into the acid and base (carbonic acid and metal oxide or hydroxide) and the weaker the base the more marked is this action. The precipitate from solutions of salts of strong bases, such as calcium chloride, is the normal carbonate; a weaker base, such as nickel, is precipitated as basic carbonate or a mixture of the normal carbonate with hydroxide or oxide; while the very weak bases, as iron in ferric salts, are precipi- 
tated as hydroxide or oxide containing little or no carbonate, and the corresponding quantity of carbon dioxide is set free:

$$
\begin{gathered}
\mathrm{CaCl}_{2}+\mathrm{Na}_{2} \mathrm{CO}_{3}=\mathrm{CaCO}_{3}+2 \mathrm{NaCl} ; \\
2 \mathrm{NiCl}_{2}+2 \mathrm{Na}_{2} \mathrm{CO}_{3}+\mathrm{H}_{2} \mathrm{O}=\mathrm{NiCO}_{3}, \mathrm{Ni}(\mathrm{OH})_{2}+\mathrm{CO}_{2}+4 \mathrm{NaCl} \\
2 \mathrm{FeCl}_{3}+3 \mathrm{Na}_{2} \mathrm{CO}_{3}+3 \mathrm{H}_{2} \mathrm{O}=2 \mathrm{Fe}(\mathrm{OH})_{3}+3 \mathrm{CO}_{2}+6 \mathrm{NaCl}
\end{gathered}
$$

The action of a silicate may be expected to be similar to that of the carbonate, with the difference that the silicate, as the salt of a weaker acid than carbonic, will tend to produce a more basic precipitate-that is, one containing more hydroxide.

The hydroxide of the metal, with more or less silicate and an amount of silica corresponding to the quantity of precipitated hydroxide, will therefore make up the precipitate in case the solution and the precipitant come together under such conditions that the metal is completely precipitated. When insufficient alkali for complete precipitation is added to a metal salt solution the resulting precipitate is in some cases a basic salt where with excess of alkali it would be a hydroxide. Cupric sulphate, for instance, with alkali in excess gives $\mathrm{CuSO}_{4}+$ $2 \mathrm{KOH}=\mathrm{Cu}(\mathrm{OH})_{2}+\mathrm{K}_{2} \mathrm{SO}_{4}$; but where the copper salt is in excess the result is $4 \mathrm{CuSO}_{4}+6 \mathrm{KOH}=\mathrm{Cu}_{4}(\mathrm{OH})_{6} \mathrm{SO}_{4}+3 \mathrm{~K}_{2} \mathrm{SO}_{4}$. The same basic salt is formed by calcium carbonate or by such silicates as glass, acting on excess of cupric sulphate solution. There seems to be, therefore, reason to expect that in the precipitations with which we are here concerned the same basic salt will play an important part. As a matter of fact, in the cases of enstatite and epidote contact with cupric sulphate caused the formation of a coating on the flask wall which contained copper and sulphate and was insoluble in water, and was therefore basic copper sulphate. After filtration of shale from cupric sulphate solution a similar precipitate formed.

That the silicate of the metal is actually formed to some extent when orthoclase, for instance, is brought into contact with metal salt solutions is evident in the case of the sodium salt, where precipitation as hydroxide is out of the question. The experiment shows also that although barium is precipitated $\left(50 \mathrm{~cm}^{3}\right.$ solution lose 0.0802 gram $=0.58$ millimol barium) the resulting solution remains neutral to litmus and hence contains practically no barium hydroxide whatever. Barium has therefore not been precipitated from this solution in the form of hydroxide, for this would necessitate the formation of a saturated solution of that compound. The conclusion seems inevitable that the barium which has left the solution is in combination as a silicate.

Further evidence that the silicate of the precipitated metal is formed is found in the fact that the reverse reactions can be made to take place, while the precipitation of hydroxide or basic sulphate of copper is under these conditions practically an irreversible reaction. Orthoclase treated with cupric sulphate solution gives up potassium 
for copper, which is precipitated. The resulting slightly green powder, washed until water extracts at most a minute trace of copper, if treated with potassium sulphate solution gives up copper in considerable quantity, thus reversing the first reaction. Precipitated cupric hydroxide or basic sulphate similarly treated with potassium sulphate solution gives up no copper. The following are the experimental data on this point:

The copper is not extracted from the orthoclase by water: $50 \mathrm{~cm}^{3}$ water stirred up with 25 grams of washed and air-dried orthoclase which had taken 0.073 gram copper from solution dissolved a scarcely weighable trace (about 0.05 milligram) of the metal.

The copper is extracted by potassium sulphate solution: After washing, as just described, and freeing from water by suction $50 \mathrm{~cm}^{3}$ potassium sulphate solution of normal concentration were stirred up with the orthoclase and the solution was then filtered. Fifty $\mathrm{cm}^{3}$ filtrate now contained 0.008 gram copper.

Copper is not extracted from cupric hydroxide or basic cupric sulphate by potassium sulphate solution: Fifty $\mathrm{cm}^{3}$ cupric sulphate solution (0.127 gram copper) was precipitated with sodium hydroxide, and after thorough washing neither water nor potassium sulphate solution dissolved copper from the precipitate. About one gram basic cupric sulphate was prepared by treating cupric sulphate with insufficient sodium hydroxide for complete precipitation. After thorough washing water still dissolved a trace of copper from the product. The solubility in potassium sulphate solution was not appreciably greater.

Another sample of orthoclase treated as above described gave a similar result. Several successive extractions with potassium sulphate solution yielded decreasing quantities of copper. Anthophyllite after contact with cupric sulphate and washing gave only a trace of copper when extracted with water. Fifty $\mathrm{cm}^{3}$ potassium sulphate solution, however, removed about 0.006 gram copper. Vesuvianite which had been treated with cupric sulphate solution of such dilution that the copper was completely precipitated gave up no copper on extraction with potassium sulphate solution, owing probably to the precipitation of the copper entirely as hydroxide where the precipitant is in excess, as it was in this case.

Van Bemmelen ${ }^{a}$ shows that salts which are not removed from a colloid by water may be dissolved by means of another salt solution. Calcium chloride, for instance, in a well-washed preparation of chromic hydroxide, was taken out by a concentrated solution of potassium sulphate. There is no reason to believe that the copper extracted from orthoclase and other silicates, as just described, was in a condition similar to that of the calcium chloride in Van Bemmelen's experiment. 


\section{SUMMARY.}

The natural silicates precipitate the metals from solutions of salts, while at the same time the bases of the silicates are dissolved in quantities nearly equivalent to the precipitated metals. The bases most commonly replacing the metals in these processes are potassium, sodium, magnesium, and calcium. Where exact equivalence is wanting, it is attributable either to solubility of the mineral in pure water or to the precipitation of basic salts.

The metals are precipitated as hydroxides or basic salts (in the case of cupric sulphate, for instance, as a basic cupric sulphate similar to brochantite or langite) with more or less metal silicate.

The specific materials on which work was done are albite, amphi-. bole, augite, biotite, enstatite, garnet, clay gouge, kaolin, microcline, muscovite, olivine, orthoclase (3), prehnite, shale, talc, tourmaline, and vesuvianite, with cupric sulphate solution; and orthoclase with salts of sodium, potassium, magnesium, calcium, strontium, barium, manganese, iron, nickel, copper, zinc, silver, gold, and lead. Experiments were also made on the action of kaolin on solutions of salts of zinc and iron, and of glass, fluorite, and pyrite on cupric sulphate and of carbonic and sulphuric acids on orthoclase.

Adsorption, a mechanical surface attraction, plays a comparatively insignificant part, if any, in the retention of copper by kaolin. If adsorption is lacking in the case of kaolin, it-seems reasonable to assume that it is lacking in the case of other silicates also.

Under the conditions of the experiments described the precipitation of copper caused by orthoclase does not differ materially in quantity from that caused by pyrites.

A dilute salt solution decomposes orthoclase and dissolves its constituents to about the same extent as does a saturated solution of carbonic acid. Both are much more efficient in this respect than water.

Orthoclase (and presumably other alkali silicates also) accelerates the oxidation of ferrous sulphate by the oxygen of the air. A similar influence may be expected in other oxidation reactions that take place more readily in the presence of alkali than in the presence of acid.

It is worthy of note that the iron of ferrous silicates is not found in solution replacing copper after the precipitation of the latter. This was also true of the iron in a clay gouge containing considerable ferrous carbonate.

The writer wishes to acknowledge gratefully suggestions and assistance from various geologists of the Survey, especially from Mr. W. H. Weed and Mr. Waldemar Lindgren. $\mathrm{He}$ is also under obligation to Prof. G. P. Merrill and Mr. Wirt Tassin, of the National Museum, and others for minerals furnished. 


\section{N D E X.}

A.

Absorption, nature of of bases, dependence of, on quantity of solution......................

Actic acid, action of, on decomposed granite

Acid ion, precipitation of

Acidity of salt solutions after filtration, cause of.

Acids, nature of action of, on alumino-silicates.

. separation of bases from, in salt solutions, by diffusion..............

Adsorption, extent of. (footnote)
(forsion of, reference to... 36

phenomena of ..................... $7,8,25$

Albite, experiments with................ 51

Alkali, free, absorption of, by quartz, experiment showing.............. absorption of, by soils............... 28-29 action of, on silicates, nature of ....... 29

Alkali salts, action of, on granite.......... 27

Alkaline solutions, absorption from, as compared with absorption from neutral solutions ........... 12,13,15

action of clay, etc., on .............. 28-31

Alumino-silicates, absorption by, from salt solutions......................

relative stability of $. . . \ldots \ldots \ldots \ldots \ldots . . .$.

Aluminum, amount of, dissolved by acid solution......................

Aluminum oxide, action of, on salt solutions.................... 20,28, 30

Ammonia, absorption of, by soil, from salts of ammonium........... 11, 13-14, 19

absorption of, from ammonium hydroxide solutions...............

Ammonium, substitution of, for other bases in silicates............... 12,21,22

Ammonium alumino-silicate, preparation

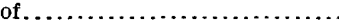

Ammonium carbonate, absorption of, by ferric oxide

absorption of by chabasite ................

Ammonium chloride, absorption of, by ferric oxide......................

action of, on chabasite................

action of, on granite.................

reaction of, with ferric oxide...........

Ammonium hydroxide, reaction of, with soil ..........

Bull. $312-07-5$
Page.

Ammonium phosphate, reaction of, with soil...................... 13-14

Ammonium salts, absorption of acid radical from, by ferric oxide........ $\quad 30$

ammonium absorbed by soil from...... 13

reaction of, with soil and minerals... 11,13-14

Ammonium substitution compounds, action of ...................... 13,21

Ammonium sulphate, reaction of, with ferric oxide.................. 19,30

Amphibole, experiments with............ 53-54

Analcite, absorption of sodium from, by ammonium chloride solution...... 22

transformation of, to leucite....... 20-21,34

Anion, influence of, in action of soils on solutions of potassium salts, table showing...................... 14

Anthophyllite, experiment with........... 53

Aristotle, on filtration................... 7

Armsby, H. P., on law of mass action as applied to absorption of bases by silicates..................... 33-34

Augite, experiments with.............. 52-53

Auric chloride, experiments with.......... 41

\section{B.}

Bacon, Francis, on filtration of sea water.. 7

Barium, precipitation of, form of......... 62

Barium chloride, experiments with........ 41, 49

Bases, absorption of, by alumino-silicates, order of ................. 12,13,22

absorption of, dependence of, on quantity of solution................ 14

exchange of, acidity caused by........ 8

replacement of, by potassium, in experiments with soil............... 15

separation of, from acids, by diffusion in solutions.................... 9

Bauxite, experiments with.............. 26

Becker, G. F., on concentration of metals by dialysis................... 8

Becquerel, experiments by................ 60

Bemmelen, J. M. van, experiments by ... 23-25, 63

on absorption of salts by soil......... 24,25

on electrolytic dissociation as explaining reactions of salts and minerals. .

on holding of electrolytes by colloids...

on hydrous oxides....................

on influence of calcium carbonate......

on precipitation of acid radical as affected by extraction with acid..

on reaction between alkali and silicates.

Berzelius, J. J., on filtration. 
Biotite, experiment with..................
Bischof, G., on assimilation of potassium rather than sodium by plants...

Bödeker, C., on relation between concentration of solution and amount of absorption.

Page.

Colloids, action of, on salt solutions...... 25,27-28 equilibrium between solutions and...... 35

impermeability of clay to.............. 9

Concentration of metals by dialysis, possibility of..................... 8

Borate radical, precipitation of, by acidextracted soil.

Borax solution, experiments with...........

Briggs, L. J., on action of alkali on quartz... on adsorption of salts by quartz........ on changes in concentration of solutions caused by filtration.............

Brochantite, possible mode of formation of. $60-61$

Bronzite, experiment with.................

Bruni, G., on separation of acid and base by diffusion.

c.

Calcite, experiments with............... 59-60

Calcium, absorption of, by silicate, experiment showing.

replacement of, by magnesium, in silicates....................... 22

Calcium carbonate, influence of............ 31-33

Calcium chloride, action of, on granite...... $\quad 27$

action of, on sodium alumino-silicates... 33-34

experiments with ............ 26,41,48,61,63

Calcium oxide, absorption of, by soils, experiments showing...............

Calcium phosphate, action of, on ferric and aluminum oxides.

Calcium salts, precipitation of acid ions as..

Calcium silicates, stability of, as compared with magnesium silicates.......

Cameron, F. K., and Bell, J. M., on literature of research concerning reactions between salt solutions and silicates.

Carbonate radical, precipitation of, by acidextracted soil.

Carbonates; absorption of, by quartz...... precipitative action of, compared with that of silicates.....

Carbonic acid, action of, on substituted potassium....................

removal of bases from silicates by ... $32,50,51$.

Carnallite, metamorphism of clay by...... 32

Chabasite, experiments with.......... 12-13,22

Charcoal, absorption of potassium chloride by ........................ 15

Chloride ion, nonabsorption of, by soil..... 15,16

Clarke, F. W., and Steiger, George, experiments by, showing substitution of bases.....................

Clausius, R., electrolytic dissociation theory of, cited to explain reactions of salts and minerals .............

Clay, absorption of bases from salt solutions by .......................

filtration of salt solutions through, results of.

metamorphism of by overlying carnollite bed......................

permeability of, to solutes.............

Clay gouge, experiments with..............

17

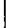

Concentration of solutions, influence of..... 12,

$$
14,34-36,42
$$

lated to..................... 11,14

Copper, nonreplacement of, by iron of ferrous silicates.................. 64

Crystalloid solutes, permeability of clay to... 9

Cupric chloride, experiments with........ 41,44

Cupric nitrate, experiments with........... 41, 43

Cupric oxide, action of, on salt solutions.... 28

Cupric sulphate, experiments with ....... 8, 9-10, $38-39,40,41-43,51-60,62-63$

filtration of solution of, effect of....... 8,9

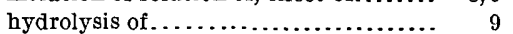

precipitates from................... 62

experiment with..................... 9

Cushman, A. S., experiments by, showing action of water on silicates.....

on dissolution of orthoclase by ammonium chloride solution............

on removal of barium and aluminum from solution by China clay....

\section{D.}

Decomposition, double, acidity caused by... Deposition of metallic ores, factors in.......

Desmin, experiment with..................

Dialysis, concentration of metals by.......

Diffusion, acidity caused by, after filtration.

Dittrich, M., on reaction between granite and salt solutions..............

Duschak, L. H., and Hulett, G. A., on correction for chlorine.............

\section{E.}

Eichhorn, H., experiments by ........... 12-13 on destruction of absorptive power of silicates by acid................

on reactions between salt solutions and natural minerals................

Electrolytic dissociation theory, citation of, by van Bemmelen to explain reactions of salts and minerals ...

Enstatite, experiment with ...............

Epidote, experiments with .............. 55-56

Experimental work, methods followed in... 37 results of............................ $38-60$

\section{F.}

Feldspars, reaction of with salt solutions. 11-12, 26

Ferric oxide, absorption of potash by...... $\quad 30$ absorption of salts by ................ 19 action of, on salt solutions.............. 28

Ferric salts, precipitates from........... 61-62 Ferric sulphate, experiments with....... 41, 46-47 hydrolysis "of...................... 9 Ferrous sulphate, experiments with....... 41, 46 Filtration, effect of, on salt solutions....... $7,8,9$ Fluorite, experiments with .............. 60 Freundlich, Herbert, on adsorption ......... 36 
G.

Page.

Garnet, experiment with

Garrey, G. H., aid by.

Geologic phenomena, application of experiments to.................... $60-61$

Glass, experiments with.

Gold chloride, experiments with............

Granite, action of salt solutions on.......... 26-27

$G$ rinding of the minerals, influence of extent or fineness of.

H.

Hales, Stephen, on filtration of sea water...

Henneberg and Stohmann, experiments of..

on absorption of free alkali............ 28-29

Hillobrand, W. F., aid by

Hintz, E., and Weber, H., on means of preventing precipitation of alkali sulphite with barium sulphate.

Hornblende granite, action of salt solutions on........................ 26-27

Hulett, G. A., and Duschak, L. H., on correction for chlorine.............

Hydrochloric acid, action of, on decomposed granite.

destruction of absorptive power for acid radical by ....................

effect of extraction of clay by, on absorption of free alkali...............

extraction of soils with, effects of....... 28,31

Hydrolysis, influence of, in causing acidity after filtration :

Hydrous oxides, water of ...........................

Hydrous silica, behavior of, toward solutions.

I.

Iceland spar, experiment with.

Iron of ferrous silicates, non-replacement of copper by

$$
\text { J. }
$$

Joly, J., experiments by, showing action of sea water on rocks and minerals.

\section{$\mathrm{K}$.}

Kaolin, experiments with filtration of salt solutions through....

King, F. H., on changes in concentration of solutions caused by filtration. ..

Kohler, Ernst, on adsorption...............

on filtration of salt solutions through kaolin.

Krawkow, S., on motion of solutions in soils.

Küllenberg, O., experiments by, showing absorption by soil from salt solutions....................... 16-19

on removal of phosphate radical from salts by soils.

\section{L.}

Lagergren, S., experiments by, on adsorption of salts by kaolin and other substances

\section{I}

tion on ...................... 26

Lead nitrate, experiments with......... $8,41,44$

solution of, filtration of, effect of...... 8

Lemberg, J., experiments of........... 20-23, 32

- on absorption of potassium rather than sodium by plants............. '22

on action of carbonic acid on silicates... 50

on assimilation of potassium by plants, chemical cause of ...............

on nature of processes involved in his experiments...................

on transformation of clay by calcium carbonate.................... 32-33

on transformation of the feldspars.... 23

Leucite, transformation of analcite to..... $\quad 34$

transformation of, to analcite......... 20-21

Liebig, Justus, on mechanical or physical action of soils in absorbing bases from salts................. 15-16

on precipitation of silicate radical..... 30

Lime, absorption of, by soils, experiments showing..................... 17

Lindgren, Waldemar, acknowledgments to. $\quad 64$ aid by.......................... 38,58

on occurrence of brochantite........... $60-61$

Lunge, $\mathrm{G}$. , on means of preventing precipitation of alkali sulphate with barium sulphate...............

\section{M.}

Magnesia, absorption of, by soils, experiments showing.................

Magnesium, replacement of, by calcium in silicates..................... 22

Magnesium chloride, action of, on granite.. $\quad 27$ experiments with:.................. 8,26,27

filtration of, effect of................ 8

Magnesium oxide, absorption of, by soils, experiments showing.......... 17

Magnesium salts, experiments with....... 13

Magnesium silicates, stability of, as compared with calcium silicates....

Magnesium sulphate, action of, on wollaistonite....................... 20

experiments with............... 41,47-48

Manganese dioxide, action of, on salt solutions........................ 28

Manganous sulphate, experiments with... 41,47 Mass law, application of ............... 33-34 Matteucci, Carlo, on filtration............ 7 Mercuric oxide, action of, on salt solutions. $\quad 28$ Merrill, G. P. acknowledgments to........ 64

on zeolitic silicates in soils ............ 11

Metastannic acid, action of, on salt solutions...................... 28

colloidal, experiments with............ 35

Metathesis, acidity caused by ............. 10 Meyerhoffer, W., experiments by, showing reaction between potassium carbonate and bairum sulphate....

Microcline, experiment with................

Millimol, definition of. ...................

Mineral surface exposed to action of salt so- 
Minerals used in experiments, pulverization of, influence of fineness of.......

Müller, R., on action of carbonic acid solutions on minerals.............

Muscovite, experiment with.

N.

Natrolite, experiment's with

Neutral solutions, absorption from, as compared with absorption from alkaline solutions. .......... 12,13,15

Nickel salts, precipitates from............ 61 Nickel sulphate, experiments with...... 41, 47

\section{O.}

Ocean; saltiness of, chemical causes of. ..... 22-23 Olivine, experiment with. . . . . . . . . . . 54-55 Ore deposition, factors in. ............ 5-6 Orthoclase, acceleration of oxidation of ferrous sulphate by.

action of water on

replacement of potassium by copper in, when treated with cupric sulphate .....................

specimen of, used in experiments, source of. .

Ostwald, W., experiments by, showing solubility of alkaline-earth sulphates in acids.

Oxides, hydrous, water of

$$
\text { P. }
$$

Peters, E., experiments by ............. 14-15 on destruction of absorptive power of silicates by acid.

on mechanical or physical action of soils in absorbing bases from salts...

Phosphate ion, absorption of, by soil ...... Phosphate radical, precipitation of, by acidextracted soil.

Plants, assimilation of potassium by, rather than sodium..............................

Potassium, absorption of, experiments showing ..................

assimilation of, by plants, chemical cause of . . . . . . . . . . . . . . . . . .

Potassium alumino-silicates, experiments with . . . . . . . . . . . . . . 22,32

Potassium carbonate, interaction of, with ferric oxide

Potassium chloride, absorption of, by charcool ....

absorption of, by ferric oxide.

action of colloid oxides on...

action of, on granite................

reaction of, with oxides of metals.......

action of soils on solution of. ...........

experiments with ...... 15, 23, 25, 26, 27, 29, 49

Potassium hydroxide, absorption of, by clay ........................

action of, on silicates, nature of.......

reaction between silica and........... Potassium nitrate, absorption of, by ferric oxide....................................

\begin{tabular}{c|} 
ge. \\
40 \\
51 \\
56 \\
$\cdot$ \\
\\
12 \\
\\
\\
3,15 \\
61 \\
47
\end{tabular}

Potassium nitrate, action of colloid oxides

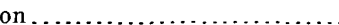

changes in concentration of solutions of, caused by filtration.............

Potassium oxide, absorption of, by ferric oxide.

absorption of, by soils.............. 18

Potassium salts, reaction of, with soil...... 13-14

Potassium silicates, relative stability of, as compared with sodium silicates.

Potassium sulphate, absorption of, by ferric oxide.

action of colloid oxides on............ 28

changes in concentration of solutions of, caused by filtration............

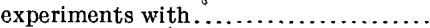

Potash, absorption of, by ferric oxide..... absorption of, by soils, experiments

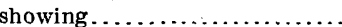

See also Potassium oxide.

Precipitates, nature of . . . . . . . . . . . . 61-64

Prehnite, experiment with ........... 56

Pulverization of minerals, fineness of, influence of.

Pyrite, experiments with

precipitation caused by, compared with that caused by orthoclase.......

\section{Q.}

Quartz, absorption of alkali by absorption of carbonates by

R.

Rautenberg, F., experiments by, showing absorption by soil from salt solutions.

on action of aluminum oxide on amm nium chloride...........................

Page.

28

Reversible reactions, occurrence of, between salt solutions and silicates...... 12,13

Rohland, P., on permeability of clays to

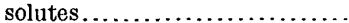

Rogers, W. B., and Rogers, R. E., on action of carbonic acid solution on minerals.......................

Rümpler, A., on reactions between silicates and alkalies...................

$\mathrm{S}$.

Salt solutions, acidity of, after filtration, cause of ................. 8-9

action of silicates on, nature of .......... efficiency of, in decomposition of sili-

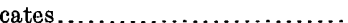

Sea, saltness of, chemical causes of . . . . . . 22-23

Sea water, experiments with............ $\quad 26$

Shale, experiments with .............. 58

Silica, amorphous, experiments with...... 32

hydrous, behavior of, toward solutions..................... 24-25

water of . . . . . . . . . . . . . . . . . . . 24

Silicates, action of, on solutions of salts, nature of ................... 27

colloid, absorption of salts by ........ 25

precipitative action of, compared with that of carbonates............ 62 
Silicates, reactions between salt solutions and, character and extent of... 6,11

Silver sulphate, experiments with ......41,44,59

Skey, W., on absorption of iron from ferric acetate solution by quartz powder ........................

Smith, Angus, on effect of sand as a filter for organic compounds.

Soda, absorption of, by soils, experiments showing.

Sodium alumino-silicates, action of calcium chloride on............... 33-34

preparation of

Sodium bicarbonate, changes in concentration of solutions of, caused by filtration.

Sodium carbonate, changes in concentrations of solutions of, caused by filtration.

experiments with.....................

increase of absorptive power by digestion with ..................... precipitates caused by.

Sodium chloride, action of, on granite...... experiments with............ 8, 12,13,22,50 filtration of, effect of. $8,12,13,22$ presence of, in sea water, chemical causes of.

Sodium phosphate, absorption of sodium
from solution of, by soil........

Sodium phosphate, absorption of sodium
from solution of, by soil........

Sodium salts, reactions of, with soils and minerals.................... 13-14

Sodium silicates, stability of, as compared with potassium silicates.

Soil, composition of, used in Küllenberg's experiments....................

Solid solution reference to discussion of... (footnote)

Spring, W., on separation of acid and base by diffusion....................

Stannic acid, action of, on salt.solutions ... Steiger, George, and Clarke, F. W., experiments by, showing substitution of bases.......................

Stohmann and Henneberg, experiments of. . 13-14 on absorption of free alkali............ 28-29

Strontium chloride, experiments with...... 41, 48

Sugar making, extraction of potassium by a silicate in process of ............

Sulphate, determination of, in cupric sulphate solution................. in ferric sulphate solution............. in sulphuric acid solution.
Sulphate ion, nonabsorption of, by soil..... 15, 16 Sulphuric acid, experiments with....... 35, 43,50 Surface of mineral exposed to action of salt solutions, influence of amount of $\ldots \ldots \ldots \ldots \ldots \ldots \ldots \ldots, 39-40$

T.

Talc experiment with ................... $\quad 57$

Tassin, Wirt, acknowledgments to........ 64

Temperature of solutions, effect of . ..... 21, 42-43

Thugutt, S., experiments by ............. 23

Time of contact, relation of extent of absorption to................. 11,14

Thompson, H. S., experiment made by..... 10

Tourmaline, experiment with............ $\quad 56$

$\mathrm{V}$.

Van Bemmelen, J. M. See Bemmelen, J. M. van

Vanzetti, B. L., on separation of acid and base by diffusion.............. 10

Vesuvianite, experiments with $\ldots \ldots \ldots \ldots \ldots 55,63$

W.

Warington, Robert, experiments by, showing absorption by oxides of iron and aluminum $\ldots \ldots \ldots \ldots \ldots \ldots 19,20$

on precipifation of acid radical by ferric and aluminum oxides.......... 30

31 Way, J. T., experiments made by ......... 10 on effect of sand and clay as a filter for organic compounds........... 12

on precipitation of acid ion............ 30

on reaction between alkali and silicates. 28

on reactions between salt solutions and silicates $\ldots \ldots \ldots \ldots \ldots \ldots \ldots \ldots, 11,12$

on removal of acids of salt solutions by soils........................ 30

Weber, H., and Hintz, E., on means of preventing precipitation of alkali with barium sulphate......... 50

Weed, W. H., acknowledgments to ......... 64

Wolff, on relation between concentration of solution and amount of absorption.

Wollastonite, action of magnesium sulphate on....................... 20

Wood charcoal, absorption of potassium chloride by.................. 15

Z.

Zeolitic silicates in soil, observation on..... 11 Zinc sulphate, experiments with.......... 41,45 